UNIVERSIDADE DE SÃO PAULO

FACULDADE DE ECONOMIA, ADMINISTRAÇÃO E CONTABILIDADE DEPARTAMENTO DE CONTABILIDADE E ATUÁRIA

PROGRAMA DE PÓS-GRADUAÇÃO EM CONTROLADORIA E CONTABILIDADE

DECOUPLING E INTEGRAÇÃO ENTRE OS MERCADOS ACIONÁRIOS DOS BRICS

Anderson de Souza Carvalho

Orientador:

Prof. Dr. Luiz Paulo Lopes Fávero

SÃO PAULO 
Prof. Dr. João Grandino Rodas

Reitor da Universidade de São Paulo

Prof. Dr. Reinaldo Guerreiro

Diretor da Faculdade de Economia, Administração e Contabilidade

Prof. Dr. Edgard Bruno Cornacchione Junior

Chefe do Departamneto de Contabilidade e Atuária

Prof. Dr.Silvia Pereira de Castro Casa Nova

Coordenadora do Programa de Pós-Graduação em Controladoria e Contabilidade 


\section{DECOUPLING E INTEGRAÇÃO ENTRE OS MERCADOS ACIONÁRIOS DOS BRICS}

Dissertação apresentada ao Departamento de Contabilidade e Atuária da Faculdade de Economia, Administração e Contabilidade da Universidade de São Paulo, para a obtenção do título de Mestre em Ciências.

Orientador: Prof. Dr. Luiz Paulo Lopes Fávero

Versão Corrigida

(versão original disponível na Faculdade de Economia, Administração e Contabilidade)

\section{SÃo PAULO}


FICHA CATALOGRÁFICA

Elaborada pela Seção de Processamento Técnico do SBD/FEA/USP

Carvalho, Anderson de Souza

Decoupling e integração entre os mercados acionários dos BRICS /

Anderson de Souza Carvalho. -- São Paulo, 2013.

$123 \mathrm{p}$.

Dissertação (Mestrado) - Universidade de São Paulo, 2013.

Orientador: Luiz Paulo Lopes Fávero.

1. Mercado de capitais 2. Finanças internacionais 3. Integração financeira 4. Brics 5. Decoupling I. Universidade de São Paulo. Faculdade de Economia, Administração e Contabilidade. II. Título.

$$
\text { CDD - 332.041 }
$$


À minha querida mãe, Adeilda, pela sua história de superação e pelo seu amor sem fim. 


\section{AGRADECIMENTOS}

Ao meu orientador, Prof. Dr. Luiz Paulo Lopes Fávero, pela sua confiança em meu potencial, pelo exemplo de profissionalismo, pelo suporte em forma de sugestões brilhantes para o trabalho ou em forma de motivação nos momentos difíceis.

Ao Prof. Dr. Iran Siqueira Lima, membro da banca, pelo seu infindável conhecimento sobre o mercado financeiro, pela disponibilização das instalações da FIPECAFI para a realização de parte desta pesquisa e pelos seus conselhos sobre carreira que sempre vou levar comigo.

Ao Prof. Dr. Wilson Toshiro Nakamura, membro da banca, pelas contribuições valiosas para esta dissertação, pela sua pronta disposição em ajudar e pelo convite a palestras que foram cruciais para o desenvolvimento dessa pesquisa.

À Coordenação de Aperfeiçoamento de Pessoal de Nível Superior, CAPES, pelo apoio financeiro que foi imprescindível para que eu pudesse focar somente na presente pesquisa.

À colega Tatiana Albanez, do CEMEC, pela ajuda na coleta dos dados para a pesquisa.

Ao amigo Janilson Suzart, doutorando, pela amizade e pelas suas contribuições a essa pesquisa, com seu vasto conhecimento sobre econometria.

Ao amigo Marcos Pinto, doutorando, que contribuiu com palavras de incentivo e conselhos sobre quais direções seguir com a minha carreira.

A todos os outros colegas, funcionários e alunos, que conheci no EAC, pelos momentos de aprendizagem e de descontração.

À minha família, que sempre me apoiou e sempre acreditou em mim, principalmente minha querida mãe, Adeilda, cujos inumeráveis esforços para que eu pudesse estudar foram minha principal fonte de motivação e de inspiração. 


\section{RESUMO}

\section{CARVALHO, A. S. Decoupling e integração entre os mercados acionários dos BRICS.}

Dissertação (Mestrado). Faculdade de Economia, Administração e Contabilidade, Universidade de São Paulo, São Paulo, 2013.

Com o crescimento do comércio entre os países emergentes na última década, um aumento do fluxo de capitais entre esses países tem sido observado, o que defende a hipótese de integração financeira crescente entre esses países e seus respectivos mercados acionários. Ao mesmo tempo, essa categoria de comércio tem gerado um fator grupo que tem explicado parte da diferença significativa de desempenho econômico entre os países emergentes e os desenvolvidos, conhecida como decoupling. Esta pesquisa pretende investigar se existe um fenômeno de decoupling entre os mercados acionários dos BRICS e dos EUA e se esse fenômeno pode ser explicado pela integração entre os mercados dos BRICS de 2003 a outubro de 2012. Foram analisados modelos em que a variável dependente é a diferença absoluta de desempenho entre um portfólio com índices dos mercados acionários dos BRICS e o índice S\&P500 do mercado norte-americano. A variável independente consistiu de proxies para integração entre os mercados acionários dos BRICS. Os modelos foram analisados antes e depois da crise financeira de 2008. Adicionalmente, foram gerados modelos sem a inclusão do mercado chinês para verificar seu impacto na relação entre as variáveis estudadas. Entre os resultados, foram encontradas evidências de: (i) um possível decoupling entre os desempenhos dos mercados dos BRICS e dos EUA, principalmente de 2003 a 2006; (ii) uma influência significativa da integração dos mercados acionários dos BRICS no decoupling identificado; (iii) um impacto relevante do mercado chinês nos fenômenos analisados; e (iv) mudanças importantes nos resultados antes e depois da crise financeira de 2008. Esses resultados suportam a hipótese de que a recente interação entre os mercados emergentes tem produzido um fator grupo que tem gerado desempenhos significativamente diferentes dos mercados desenvolvidos, tendo implicações importantes para a teoria da diversificação internacional de portfólios.

Palavras-chave: Mercado de Capitais, Finanças Internacionais, Integração Financeira, BRICS, Decoupling. 
ABSTRACT

CARVALHO. A. S. Decoupling and integration in BRICS stock markets. Dissertation (Master's degree). Faculdade de Economia, Administração e Contabilidade, Universidade de São Paulo, São Paulo, 2013.

With the growth of the trade between emerging countries in the last decade, an increase in the capital flow between these countries has been observed, which defends the hypothesis of rising financial integration between these countries and their respective stock markets. At the same time, this category of trade has generated a group factor that has explained part of the significant difference of economic performance between emerging and developed countries, known as decoupling. This research aims to investigate if there is a decoupling phenomenon between the BRICS stock markets and the US market and if this phenomenon can be explained by the integration between the BRICS markets from 2003 to October of 2012. I analyzed models in which the dependent variables is the absolute difference of performance between a portfolio with indexes of BRICS stock markets and the S\&P500 index of the north american market. The independent variable consisted of proxies to the integration of the BRICS stock markets. I analyzed the models before and after the financial crisis of 2008 . Additionally, models were generated without the inclusion of the chinese market in order to verify its impact on the relation between the studied variables. Among the results, I found evidences of: (i) a possible decoupling between the performances of BRICS and US markets, mainly from 2003 to 2006; (ii) a significant influence of the integration between BRICS markets and on the identified decoupling; (iii) a relevant impact of the chinese market on the analyzed phenomena; and (iv) important changes on the results before and after the financial crisis of 2008. These results support the hypothesis that the recent interaction between the emerging markets has produced a group factor that has generated performances significantly different from the developed countries, having important implications to the theory of international diversification of portfolios.

Keywords: Capital Market, International Finance, Financial Integration, BRICS, Decoupling. 


\section{SUMÁRIO}

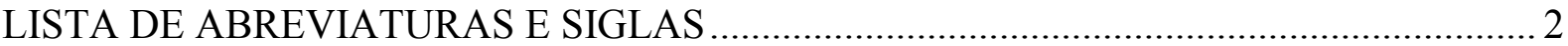

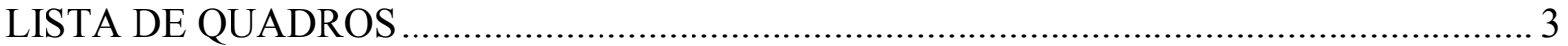

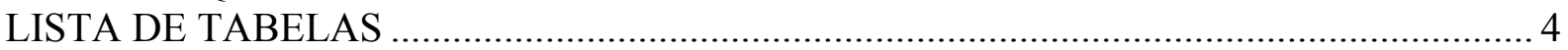

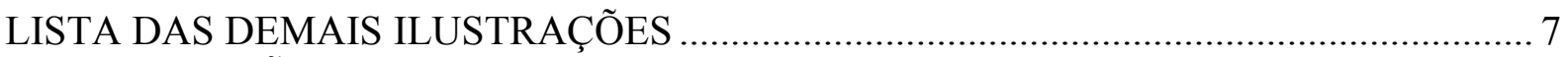

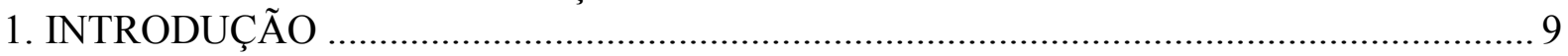

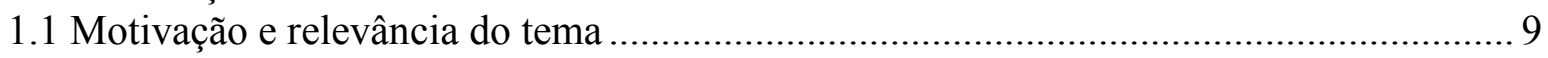

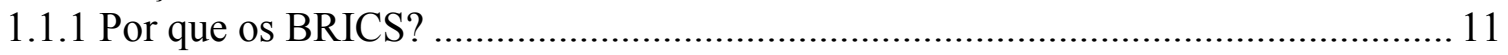

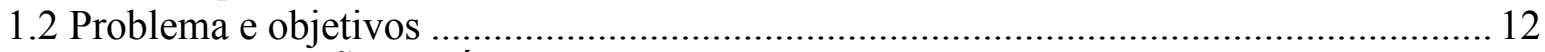

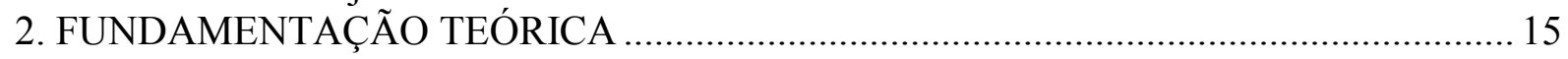

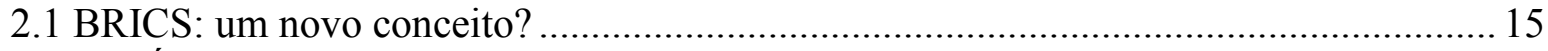

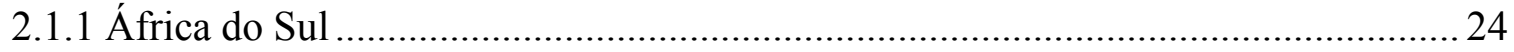

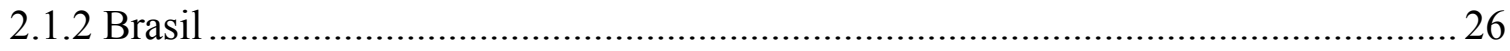

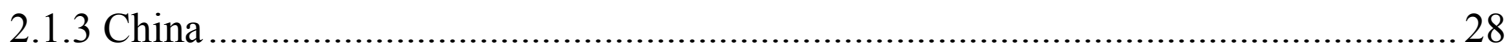

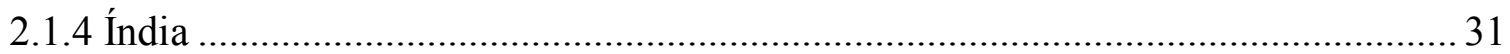

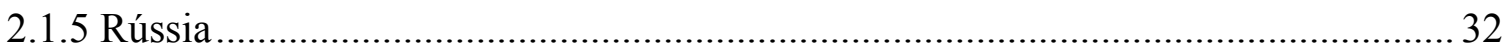

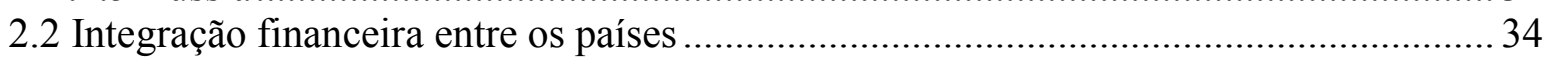

2.3 Transmissão e contágio nos mercados de ações ........................................................ 42

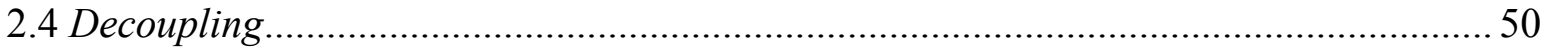

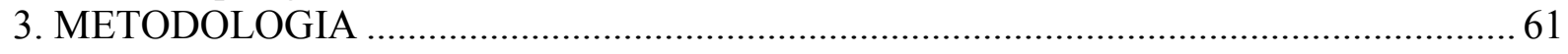

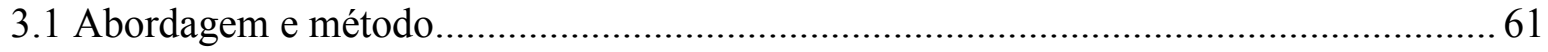

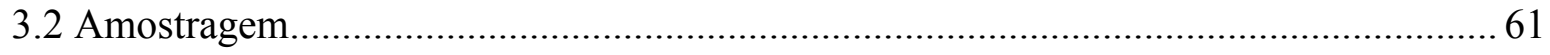

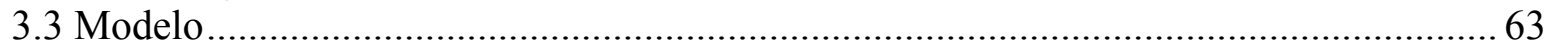

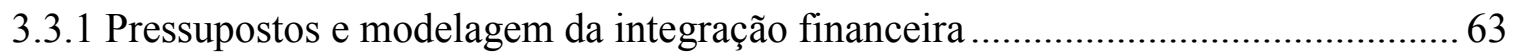

3.3.2 Pressupostos e modelagem da relação de decoupling ............................................ 69

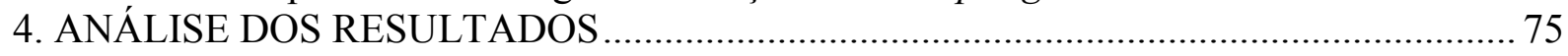

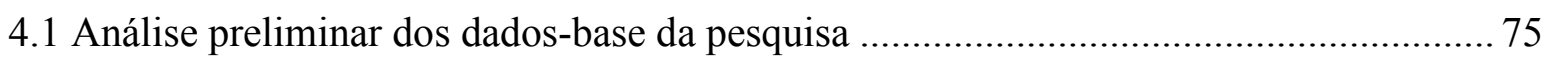

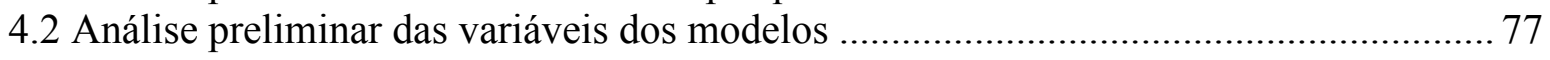

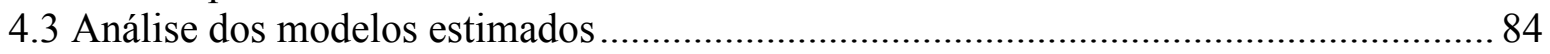

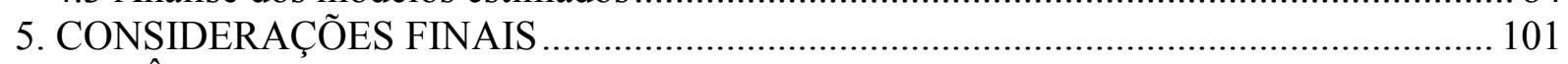

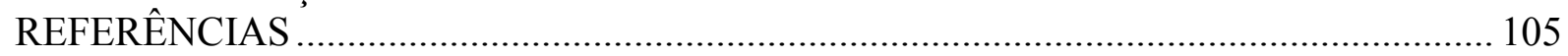


LISTA DE ABREVIATURAS E SIGLAS

ADR: American Depositary Receipt

BRIC: Brasil Rússia Índia China

BRICS: Brazil Russia India China South Africa

BRIS: Brazil Russia India South Africa

CEI: Comunidade dos Estados Independentes

CIA: Central Intelligence Agency

DRR: Distância Risco-Retorno

FMI: Fundo Monetário Internacional

GDR: Global Depositary Receipt

IDE: Investimento Direto Estrangeiro

MQG: Método dos Mínimos Quadrados Generalizados

MQO: Método dos Mínimos Quadrados Ordinários

NAFTA: North American Free Trade Agreement

NGR: Nível de Globalização Restrita

OECD: Organisation for Economic Co-operation and Development

ONU: Organização das Nações Unidas

PIB: Produto Interno Bruto

TLD: Teoria pelo Lado da Demanda 


\section{LISTA DE QUADROS}

Quadro 1- Alguns trabalhos e suas contribuições para o estudo do tema BRICS 59

Quadro 2 - Alguns trabalhos e suas contribuições para o estudo do tema integração financeira

Quadro 3 - Alguns trabalhos e suas contribuições para o estudo do tema transmissão financeira e contágio 59

Quadro 4 - Alguns trabalhos e suas contribuições para o estudo do tema decoupling 60

Quadro 5 - Países e respectivos índices dos mercados de ações coletados..... 62

Quadro 6 - Índices utilizados no modelo “A” que será base de comparação........................... 71

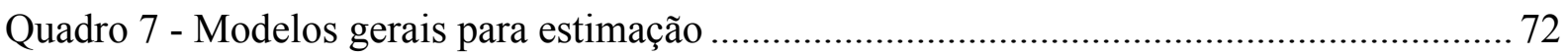

Quadro 8 - Testes utilizados e suas respectivas hipóteses nulas .......................................... 74

Quadro 9 - Resumo dos resultados das regressões referentes ao modelo geral A ................... 98

Quadro 10 - Resumo dos resultados das regressões referentes ao modelo geral B ................. 98

Quadro 11 - Resumo dos resultados das regressões referentes ao modelo geral C .................98

Quadro 12 - Resumo dos resultados das regressões referentes ao modelo geral D ................ 98

Quadro 13 - Resumo dos resultados das regressões referentes ao modelo geral E................. 99

Quadro 14 - Correspondência entre os resultados encontrados e os resultados de trabalhos anteriores 


\section{LISTA DE TABELAS}

Tabela 1 - PIB de 2011 dos países do BRICS em dólares, ajustado pela inflação

Tabela 2 - Taxa de crescimento anual real do PIB dos BRICS e dos EUA (em \%)

Tabela 3 - PIB per capita de 2011 dos países do BRICS e dos EUA em US\$, ajustado pela inflação

Tabela 4 - Índice de Desenvolvimento Humano padrão e ajustado pela desigualdade social de 2011 dos BRICS, da Noruega e do Congo.

Tabela 5 - Participação relativa nas exportações do país de origem em 2001 (em \%) ............ 22

Tabela 6 - Participação relativa nas exportações do país de origem em 2011 (em \%) ............ 22

Tabela 7 - Participação relativa nas importações do país destino em 2001 (em \%) ................ 22

Tabela 8 - Participação relativa nas importações do país destino em 2011 (em \%) ................ 23

Tabela 9 - Análise preliminar dos retornos dos índices mensais de 2001 a outubro de 2012.. 75

Tabela 10 - Análise preliminar dos log-retornos dos índices mensais de 2001 a outubro de

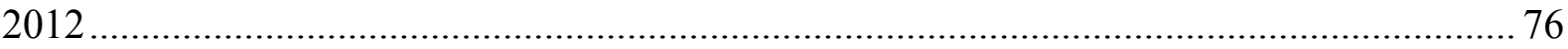

Tabela 11 - Participação por índice do mercado de cada país na carteira BRICS ................... 76

Tabela 12 - Participação por índice do mercado de cada país na carteira BRIS ...................... 77

Tabela 13 - Análise preliminar dos retornos de 2003 a outubro de 2012 das carteiras formadas

Tabela 14 - Análise preliminar dos log-retornos de 2003 a outubro de 2012 das carteiras formadas

Tabela 15 - Análise preliminar da variável dependente de fevereiro de 2003 a outubro de 2012

Tabela 16 - Análise preliminar da variável independente correlação média de fevereiro de 2003 a outubro de 2012 .

Tabela 17 - Análise preliminar da variável independente DRR média de fevereiro de 2003 a outubro de 2012 .

Tabela 18 - Análise preliminar da variável independente NGR de fevereiro de 2003 a outubro de 2012

Tabela 19 - Controle de estacionariedade das regressões com a correlação média como variável independente.

Tabela 20 - Controle de estacionariedade das regressões com a DRR média como variável independente.

Tabela 21 - Controle de estacionariedade das regressões com o NGR como variável independente.

Tabela 22 - Resultados da regressão 1: decoupling no período 1, explicado pela correlação média, de acordo com o modelo geral A

Tabela 23 - Resultados da regressão 2: decoupling no período 2, explicado pela correlação média, de acordo com o modelo geral $\mathrm{A}$. 
Tabela 24 - Resultados da regressão 3: decoupling no período 1, explicado pela distância risco-retorno média, de acordo com o modelo geral A

Tabela 25 - Resultados da regressão 4: decoupling no período 2, explicado pela distância risco-retorno média, de acordo com o modelo geral A

Tabela 26 - Resultados da regressão 5: decoupling no período 1, explicado pelo nível de globalização restrita, de acordo com o modelo geral A.....

Tabela 27 - Resultados da regressão 6: decoupling no período 2, explicado pelo nível de globalização restrita, de acordo com o modelo geral A .

Tabela 28 - Resultados da regressão 7: decoupling no período 1, explicado pela correlação média, de acordo com o modelo geral B....

Tabela 29 - Resultados da regressão 8: decoupling no período 2, explicado pela correlação média, de acordo com o modelo geral $\mathrm{B}$

Tabela 30 - Resultados da regressão 9: decoupling no período 1, explicado pela distância risco-retorno média, de acordo com o modelo geral $\mathrm{B}$

Tabela 31 - Resultados da regressão 10: decoupling no período 2, explicado pela distância risco-retorno média, de acordo com o modelo geral B

Tabela 32 - Resultados da regressão 11: decoupling no período 1, explicado pelo nível de globalização restrita, de acordo com o modelo geral B .....

Tabela 33 - Resultados da regressão 12: decoupling no período 2, explicado pelo nível de globalização restrita, de acordo com o modelo geral B ....

Tabela 34 - Resultados da regressão 13: decoupling no período 1, explicado pela correlação média, de acordo com o modelo geral $\mathrm{C}$

Tabela 35 - Resultados da regressão 14: decoupling no período 2, explicado pela correlação média, de acordo com o modelo geral $\mathrm{C}$

Tabela 36 - Resultados da regressão 15: decoupling no período 1, explicado pela distância risco-retorno média, de acordo com o modelo geral C

Tabela 37 - Resultados da regressão 16: decoupling no período 2, explicado pela distância risco-retorno média, de acordo com o modelo geral $\mathrm{C}$

Tabela 38 - Resultados da regressão 17: decoupling no período 1, explicado pelo nível de globalização restrita, de acordo com o modelo geral C .

Tabela 39 - Resultados da regressão 18: decoupling no período 2, explicado pelo nível de globalização restrita, de acordo com o modelo geral C

Tabela 40 - Resultados da regressão 19: decoupling no período 2, explicado pela correlação média, de acordo com o modelo geral D

Tabela 41 - Resultados da regressão 20: decoupling no período 1, explicado pela distância risco-retorno média, de acordo com o modelo geral $\mathrm{D}$.

Tabela 42 - Resultados da regressão 21: decoupling no período 2, explicado pela distância risco-retorno média, de acordo com o modelo geral $\mathrm{D}$.

Tabela 43 - Resultados da regressão 22: decoupling no período 2, explicado pelo nível de globalização restrita, de acordo com o modelo geral D . . 
Tabela 44 - Resultados da regressão 23: decoupling no período 2, explicado pela correlação média, de acordo com o modelo geral $\mathrm{E}$

Tabela 45 - Resultados da regressão 24: decoupling no período 1, explicado pela distância risco-retorno média, de acordo com o modelo geral $\mathrm{E}$

Tabela 46 - Resultados da regressão 25: decoupling no período 2, explicado pela distância risco-retorno média, de acordo com o modelo geral $\mathrm{E}$.....

Tabela 47 - Resultados da regressão 26: decoupling no período 2, explicado pelo nível de globalização restrita, de acordo com o modelo geral E. 


\section{LISTA DAS DEMAIS ILUSTRAÇÕES}

Figura 1 - Importância da China para o comércio internacional dos outros países do BRICS em 201124

Figura 2 - Processo de homogeneização total das estruturas de preferência das demandas. 65

Figura 3 - Comovimentos entre bolsas de valores como reflexo do comércio entre os países A e B ... 66

Figura 4 - Períodos considerados para obtenção da série de NGR 68

Figura 5 - Ideias fundamentais da conjectura. 70 


\section{INTRODUÇÃO}

\subsection{Motivação e relevância do tema}

Com o fim da Guerra Fria, a configuração multipolar da nova ordem mundial tem ganhado força e, especialmente na década passada, mais países têm surgido como novos pólos e têm institucionalizado sua relevância no mundo, seja por meio de seu poder econômico ou por sua participação ativa em importantes organismos internacionais, ou mesmo pela formação de alianças regionais.

Ao se observar esses novos centros de poder, a novidade percebida na última década é a ascensão de países antes considerados "de terceiro mundo" ou do "segundo mundo" socialista (e agora “emergentes") que, nas décadas de 1980 e 1990, ainda enfrentavam significativa instabilidade política, econômica e financeira. E dentro dos fatores para essa ascensão, está uma série de medidas governamentais que compreendem desde o fortalecimento da indústria interna até a maior inserção no comércio internacional.

Do conjunto dos principais representantes desse grupo em ascensão estão África do Sul, Brasil, China, Índia e Rússia que, adicionalmente, têm empreendido iniciativas de cooperação entre si. Dessa forma, assim como as tradicionais relações comerciais e políticas Norte-Sul, as relações Sul-Sul também têm se tornado importantes.

Regularmente, os líderes desses países têm se reunido e desde 16 de junho de 2009 essa aliança multilateral se tornou oficial por meio da realização da $1^{a}$ cúpula do BRIC na Rússia, ainda sem incluir a África do Sul.

O termo BRIC é um acrônimo com as iniciais dos nomes dos países criado por Jim O’Neill, economista-chefe do Goldman Sachs, que consta no trabalho seminal de Wilson e Purushothaman (2003), primeiro que aborda o tema diretamente. Nesse trabalho, os autores apresentam a importância desse conjunto de países que, segundo suas previsões, por volta de 2050, terão a soma de seus PIBs maior que a soma dos PIBs dos países atualmente considerados ricos e desenvolvidos.

Em 2010, O’Neil apresenta a tese de que outro país que poderia entrar nesse grupo seria a África do Sul, dada a sua representatividade e importância estratégica no continente africano, além de seus fortes laços comerciais já existentes com a China (O’NEIL, 2010). 
E nesse mesmo ano, em 24 de dezembro de 2010, a África do Sul foi oficialmente aceita como membro do grupo, agora com o nome de BRICS (o "S" vem da inicial de South Africa, África do Sul em inglês).

Mesmo que a aliança oficial entre esses países ainda seja recente; na última década, o comércio entre eles cresceu consideravelmente (SANTOS, 2010). Atualmente, a China está entre os principais parceiros comerciais dos outros quatro países, tanto em termos de importação como de exportação. E, a partir desses fatos, é possível supor que esse cenário acaba por descrever uma maior integração econômica entre os países do BRICS na última década.

Paralelo a isso, Índia e China também observaram, na última década, altas taxas de crescimento econômico, principalmente em comparação com as baixas taxas dos países desenvolvidos. E mesmo com menores taxas de crescimento, Brasil e Rússia têm observado relativa estabilidade econômica, mesmo diante da crise financeira de 2008.

A esse fenômeno, em que os ciclos de negócios de países emergentes como os do grupo BRICS parecem estar mais independentes dos ciclos dos países desenvolvidos, é dado o nome de decoupling. Essencialmente, o parâmetro para estudo dessa relação tem sido o desempenho da economia dos Estados Unidos.

Colocando a análise desses novos fenômenos (integração econômica entre os países do BRICS e o decoupling) no âmbito da pesquisa em finanças, torna-se evidente, por exemplo, a demanda por maior investigação sobre os efeitos desses fenômenos nos mercados acionários desses países.

E, assim, quanto mais significativa a relação entre a evolução da economia real de um país e a evolução de seu respectivo mercado acionário, ou seja, quanto mais um espelha o outro, mais importante se torna entender os efeitos do fenômeno de um no outro, principalmente para os atuais e potenciais investidores desse mercado e também para os reguladores desse mercado.

No que diz respeito ao reflexo da integração econômica no universo dos mercados acionários, é possível argumentar que essa induz uma integração financeira entre os países, envolvendo, portanto, uma integração entre os mercados acionários que pode compreender, entre outras coisas, a livre mobilidade de capital de um mercado para outro. 
Evidências desse efeito (maior integração financeira) surgem ao se verificar o anúncio de uma aliança das bolsas dos países do BRICS em 12 de outubro de 2011 no encontro da Federação Mundial de Bolsas. Como resultado dessa aliança, já existe a listagem cruzada de alguns derivativos dessas bolsas. Além disso, essa parceria ainda objetiva o desenvolvimento de novos produtos e de uma cooperação para serviços adicionais (BMFBOVESPA, 2012).

Quanto ao decoupling, quando se analisa a evolução dos mercados acionários do BRICS durante a crise de 2008, é observável que, em média, esses mercados tiveram um desempenho superior ao desempenho dos mercados dos países desenvolvidos, caracterizando um decoupling financeiro, pelo menos desde o início da crise até a falência do banco Lehman Brothers. Ademais, a relativa recuperação de seus mercados depois da crise foi anterior à recuperação de muitos dos mercados dos países desenvolvidos (DOOLEY, HUTCHINSON, 2009).

Assim, esses efeitos também podem ser interpretados não só como efeitos, mas também como fenômenos próprios existentes no universo dos mercados acionários, sendo, então, pontuados como: 1) integração financeira crescente entre os mercados acionários do grupo BRICS; e 2) decoupling entre o desempenho dos mercados dos BRICS e o desempenho dos mercados dos países desenvolvidos. A partir daqui, quando for empregado o termo decoupling, entenda-se, portanto, o fenômeno número 2.

Dado que são fenômenos que surgiram basicamente na mesma época, tão importante quanto estudá-los isoladamente é estudar se existe uma relação entre eles. E é na investigação dessa relação que reside o foco deste estudo.

\subsubsection{Por que os BRICS?}

A escolha de analisar os países do BRICS está calcada em alguns motivos. O primeiro seria o fato de o grupo corresponder a uma aliança que abrange quatro continentes e é formada somente por países emergentes. Ademais, as ações empreendidas em virtude dessa aliança já ultrapassam a pura diplomacia. Além do acordo de cooperação de suas bolsas de valores, foi fechado um acordo para a criação de um fundo comum no valor de US\$ 100 bilhões e ainda existe um projeto para a criação de um banco dos BRICS em 2014 (TRAVAGLINI, 2013; TRAVAGLINI, DANTAS, 2013). Essas ações, conjugadas com o crescimento do comércio entre os países do grupo, tornam mais evidente a necessidade de avaliação dos fluxos de 
capital entre eles, ou seja, da integração financeira entre o grupo e suas consequências para esses países.

Da mesma forma, é nítida a necessidade de estudar os fatores geradores dos desempenhos diferenciados desses países, principalmente China e Índia, nos anos mais recentes.

\subsection{Problema e objetivos}

Resumidamente, este estudo propõe uma conjectura em que é proposto que o aumento do comércio entre os países do BRICS induz uma integração entre os mercados acionários desses países. Paralelamente, é conjecturado que a intensificação desse comércio diminui a dependência desses países em relação aos países desenvolvidos, aumentando a magnitude do decoupling entre o BRICS e os Estados Unidos. E esse decoupling acaba se refletindo nos mercados acionários. Assim, a integração financeira entre os países do BRICS acaba representando a materialização de um "fator BRICS" que impacta os mercados acionários e gera uma relação de decoupling nesses mercados.

E com base nessa conjectura, é desenvolvido um modelo matemático que se aplica à representação da evolução dos mercados acionários dos países em questão de 2003 a outubro de 2012 e que, ao serem testados, buscam verificar a validade da conjectura desenvolvida e também buscam responder à seguinte questão-problema: Qual o impacto da integração entre os mercados acionários do grupo BRICS na relação de decoupling entre os mercados do BRICS e dos EUA?

Adicionalmente, a realização deste estudo busca atingir os seguintes objetivos:

1. Contribuir para a explicação das causas das diferenças de desempenho entre mercados acionários de países emergentes e de países desenvolvidos e, por conseguinte, contribuir para a implementação de ferramentas de gestão de risco mais efetivas;

2. Investigar as origens das oportunidades de diversificação internacional de portfólios;

3. Contribuir para a análise e previsão dos possíveis impactos da crescente cooperação entre países emergentes; e

4. Estudar a relação entre a evolução da economia real e a evolução do mercado acionário em países emergentes. 
O próximo capítulo compõe a fundamentação teórica do estudo em que, inicialmente, buscase desenvolver um conceito amplo que explique o que representa o grupo BRICS. Posteriormente, são apresentados os conceitos de integração financeira, transmissão de choques nos mercados acionários, efeito contágio e decoupling. Todos esses conceitos formam o alicerce necessário para a elaboração da conjectura.

No terceiro capítulo, sobre a metodologia, é apresentada a conjectura elaborada, as equações que a representam e a descrição dos procedimentos para o teste desse modelo. O quarto capítulo apresenta a análise dos resultados. E as considerações finais são apresentadas no quinto capítulo. 


\section{FUNDAMENTAÇÃO TEÓRICA}

\subsection{BRICS: um novo conceito?}

Antes de investigar características específicas de cada país pertencente ao grupo, é preciso apresentar o que esse grupo representa como um todo. É preciso entender quais características comuns a esses países fazem com que eles se diferenciem dos outros, verificando se esse grupo BRICS representa um novo conceito ou uma nova categoria de países. Para o prosseguimento do estudo, também é necessário conhecer os aspectos gerais dos mercados acionários desse grupo.

Por se tratar de uma temática recente, ainda é latente a falta de consenso nas pesquisas sobre o que esse grupo de países significa, dificultando a definição do substrato teórico que sustenta o termo BRICS. Assim, no início dessa subseção, serão levantados os aspectos em comum entre os países do grupo que podem lançar luz à construção de uma futura definição sobre o que significa esse grupo do ponto de vista teórico, sob a perspectiva econômica, política e social.

A primeira característica relativamente similar aos cinco países compreende o fato de o grupo ser composto por grandes economias, ou seja, os valores recentemente observados de seus Produtos Internos Brutos são relativamente altos (vide Tabela 1), principalmente quando se compara com os países mais próximos em suas regiões. Exemplo disso é a África do Sul que, mesmo não estando com a sua economia entre as 20 maiores do mundo, possui o maior PIB de seu continente.

Tabela 1 - PIB de 2011 dos países do BRICS em dólares, ajustado pela inflação

\begin{tabular}{|c|c|c|c|c|c|}
\hline Medida & Brasil & Rússia & Índia & China & África do Sul \\
\hline $\begin{array}{c}\text { PIB em milhões de US\$ } \\
\text { (PPC) }\end{array}$ & 2.293 .954 & 2.383 .402 & 4.457 .784 & 11.299 .967 & 555.134 \\
\hline Posição no mundo & $7^{\mathbf{0}}$ & $6^{\mathbf{0}}$ & $3^{\mathbf{0}}$ & $2^{\mathbf{0}}$ & $25^{\circ}$ \\
\hline
\end{tabular}

FONTE: FMI, 2013. Elaborada pelo autor.

Do ponto de vista econômico neoclássico, o tamanho da economia de um país por si só não constitui condição suficiente para justificar um possível futuro promissor para um país, muito menos o futuro de liderança mundial projetado pelos primeiros estudos sobre o grupo em análise. Entretanto, do ponto de vista político e institucional, os valores dos PIBs desses países conferem uma determinada relevância simbólica que tem garantido um maior grau de influência e autonomia no cenário internacional que acaba por trazer uma série de vantagens 
para esses países. Portanto, existe um relevante bloco de influência quando se pensa nesses países unidos (BIGGEMANN, FAM, 2011; SUBACCHI, 2008; ARMIJO, 2007).

Além disso, desde a última década, quando se foca em Índia e China, é possível observar que esses países têm observado altas taxas de crescimento econômico (vide Tabela 2), chegando a mais de $8 \%$ em alguns anos, que acabam respondendo por grande parcela do crescimento da economia mundial, contrastando com as atuais baixas taxas dos países desenvolvidos (HAMMOUDEH et al., 2012; MEDEIROS, 2011).

Tabela 2 - Taxa de crescimento anual real do PIB dos BRICS e dos EUA (em \%)

\begin{tabular}{|l|c|c|c|c|c|c|c|c|c|c|c|c|c|}
\hline País & 2000 & 2001 & 2002 & 2003 & 2004 & 2005 & 2006 & 2007 & 2008 & 2009 & 2010 & 2011 & 2012 \\
\hline Brasil & 4,3 & 1,3 & 2,7 & 1,1 & 5,7 & 3,2 & 4 & 6,1 & 5,2 & $-0,3$ & 7,5 & 2,7 & 0,9 \\
\hline China & 8,4 & 8,3 & 9,1 & 10 & 10,1 & 11,3 & 12,7 & 14,2 & 9,6 & 9,2 & 10,4 & 9,3 & 7,8 \\
\hline Índia & 5,7 & 3,9 & 4,6 & 6,9 & 7,7 & 9 & 9,4 & 10,1 & 6,2 & 5 & 11,2 & 7,7 & 4 \\
\hline Rússia & 10 & 5,1 & 4,7 & 7,2 & 7,1 & 6,4 & 8,1 & 8,5 & 5,2 & $-7,8$ & 4,5 & 4,3 & 3,4 \\
\hline África do Sul & 4,1 & 2,7 & 3,7 & 2,9 & 4,5 & 5,3 & 5,6 & 5,5 & 3,6 & $-1,5$ & 3,1 & 3,5 & 2,5 \\
\hline EUA & 4,1 & 1,1 & 1,8 & 2,5 & 3,5 & 3,1 & 2,7 & 1,9 & $-0,3$ & $-3,1$ & 2,4 & 1,8 & 2,2 \\
\hline
\end{tabular}

FONTE: FMI, 2013. Elaborada pelo autor.

Assim, no contexto do BRICS, o tamanho de suas economias e o rápido crescimento do PIB também podem ser entendidos como proxies de poder e representatividade. Dessa forma, os governos dos países do grupo tendem a ter um maior poder de negociação tanto em relações internacionais comerciais usuais como em resoluções de conflitos mais urgentes, fazendo frente aos pólos tradicionais.

Além disso, esse prestígio proveniente do poder econômico capacita-os ao exercício da posição de liderança dentro de suas regiões e facilita iniciativas com os países vizinhos, inclusive com outros países subdesenvolvidos e emergentes de outras regiões, aumentando o investimento e a cooperação na relação Sul-Sul. Essas iniciativas compreendem tanto a formação de blocos supranacionais, acordos comerciais, acordos de cooperação científica, investimentos diretos, etc; fortalecendo o grupo de emergentes e subdesenvolvidos (HOLTBRÜGGE, KREPPEL, 2012; SANTOS, 2010; NAYYAR, 2008; WALZ, 2007).

Com esse novo cenário em que o Sul tende a ficar mais forte tanto política como economicamente e levando em conta outros fatores que serão apresentados mais adiante, esses novos centros de poder também contribuem para a descaracterização da antiga relação centroperiferia (SUBACCHI, 2008). 
Essa antiga relação, que compreende a alta importância dos países desenvolvidos no fornecimento de produtos industrializados, tecnologia e capital, perde força, uma vez que, na atual configuração, alguns dos países do Sul já se mostram competentes o suficiente para também fornecer esses elementos a outros países do Sul em uma cooperação mútua e, inclusive, esses países têm ajudado a abastecer os próprios países desenvolvidos com esses mesmos elementos (ALMEIDA, RIGOLIN, 2006).

Outro fato que também é semelhante aos cinco países diz respeito ao processo de liberalização financeira e comercial durante a década de 1990. Entretanto, deve-se considerar que essa liberalização se deu em diferentes graus e de diferentes maneiras para cada país.

Dentro desse amplo processo de liberalização, aconteceram reformas que abrangeram desde medidas menores que trouxeram maior transparência aos mercados até mudanças mais radicais como o fim de algumas normas protecionistas, o fim do controle rígido do câmbio e até privatizações de setores estratégicos (BEKAERT, HARVEY, LUMSDAINE, 2002; BEKAERT, HARVEY, LUNDBLAD, 2003; BROOKS, DAVIDSON, FAFF, 1997; ANDRADE, 2003).

Essa liberalização acabou por trazer maior incentivo à iniciativa privada, incluindo a iniciativa privada estrangeira, facilitando a entrada de grandes somas de investimentos diretos estrangeiros (IDEs). Assim, com maiores níveis de investimento, mais projetos são executados e logo se observa um aumento na capacidade produtiva do país que acaba gerando maiores taxas de crescimento econômico (HIRAKAWA, AUNG, 2011; BASKARAN, MUCHIE, 2008; SANTOS, 2010).

Esse processo também contribuiu para uma maior integração econômica e financeira desses países em uma amplitude regional e global, fato que traz algumas implicações que serão apresentadas nas subseções 2.2 e 2.3 .

A abertura econômica e o rápido crescimento nesses países viabilizaram mais investimentos estrangeiros, seja por meio de empresas transnacionais, seja por empréstimos concedidos por bancos estrangeiros ou mesmo por investidores individuais ou institucionais que atuem diretamente nas bolsas de valores desses países (ARMIJO, 2007). 
Esse aumento dos investimentos também pode ser explicado pelo fato de que esses países (exceto África do Sul) possuem grandes somas de reservas internacionais. As possíveis implicações da propriedade dessas reservas são explicadas na seção 2.4.

Dentre os problemas comuns aos países do grupo, pode-se citar o fato de que esses países possuem uma baixa renda per capita e também observam um grau de desigualdade social relativamente alto (SANTOS,2010). Parte desses problemas podem ser visualizados pelas tabelas 3 e 4 .

Tabela 3 - PIB per capita de 2011 dos países do BRICS e dos EUA em US\$, ajustado pela inflação

\begin{tabular}{|c|c|c|c|c|c|c|}
\hline Medida & Brasil & Rússia & Índia & China & $\begin{array}{c}\text { África do } \\
\text { Sul }\end{array}$ & EUA \\
\hline $\begin{array}{c}\text { PIB } \text { per } \\
\text { capita } \text { em } \\
\text { US\$ }\end{array}$ & 4.803 & 3.055 & 838 & 2.640 & 3.825 & 37.691 \\
\hline
\end{tabular}

FONTE: GAPMINDER, 2013. Elaborada pelo autor.

Tabela 4 - Índice de Desenvolvimento Humano padrão e ajustado pela desigualdade social de 2011 dos BRICS, da Noruega e do Congo

\begin{tabular}{|c|c|c|c|c|}
\hline País & Colocação & IDH & $\begin{array}{c}\text { IDH ajustado pela } \\
\text { desigualdade social }\end{array}$ & $\begin{array}{c}\text { Magnitude do } \\
\text { ajuste }\end{array}$ \\
\hline Noruega & $1^{\mathbf{o}}$ & 0,943 & 0,890 & 0,053 \\
\hline Rússia & $66^{\mathbf{0}}$ & 0,755 & 0,670 & 0,085 \\
\hline Brasil & $8^{\circ}$ & 0,718 & 0,519 & 0,199 \\
\hline China & $101^{\circ}$ & 0,687 & 0,534 & 0,153 \\
\hline África do Sul & $123^{\circ}$ & 0,619 & - & - \\
\hline Índia & $134^{\circ}$ & 0,547 & 0,392 & 0,155 \\
\hline Congo & $187^{\circ}$ & 0,286 & 0,172 & 0,114 \\
\hline
\end{tabular}

FONTE: ONU, 2011. Elaborada pelo autor.

Apesar de não estar disponível na Tabela 4, a África do Sul possui um alto grau de desigualdade social: seu coeficiente de Gini de 2009 computava o valor de quase 52, quando os valores relativos aos melhores cenários de distribuição de renda estão entre 25 e 30 (Banco Mundial, 2012).

As taxas de juros desses países também são relativamente altas em comparação com a taxa de juros dos EUA que é o parâmetro de comparação usado em todo o mundo. Para África do Sul, Brasil, China, Índia, Rússia e EUA, têm-se as seguintes taxas básicas anuais nominais verificadas até 30 de abril de 2013: 5\%,7,5\%,6\%,7\%, 8,25\% e 0,25\%, respectivamente (GLOBAL RATES, 2013).

Também existem características que não estão presentes em todos os países do grupo, mas estão presentes em pelo menos dois dos membros. E essas características são importantes, 
uma vez que contribuem para explicação da interação do grupo entre si e com os outros países exteriores ao grupo.

Especificamente na China e na Índia, diversas empresas transnacionais têm se beneficiado do baixo custo de engenheiros e outros especialistas de formação sólida e, por isso, esses profissionais acabam conduzindo, inclusive, projetos estratégicos de pesquisa e desenvolvimento de tecnologia sustentável dentro desses países. Com isso, China e Índia também possuem em sua plataforma de exportação com uma participação considerável de produtos e serviços desenvolvidos com tecnologia avançada (BELDERBOS, 2006).

Entretanto, existem evidências recentes de que os produtos manufaturados chineses que são exportados também são competitivos em termos de qualidade e não somente pelo fato de seus custos de produção serem baixos (KNELLER, YU, 2008).

Nesses dois países, também é válido ressaltar que a maioria da população vive em zonas rurais e é observável uma diferença significativa entre os níveis de desenvolvimento econômico da população rural e da população urbana (principalmente na China) em que essa, em média, dispõe de melhores condições que dizem respeito a renda, educação, longevidade e infraestrutura (CHENG et al., 2007).

Todos os países do grupo passaram por intenso processo de industrialização na segunda metade do século XX. Entretanto, existem diferenças importantes com relação ao papel da indústria em suas economias.

Apesar de serem economias relativamente internacionalizadas, as indústrias brasileiras e russas (com exceção do setor de petróleo e gás no caso russo) estão mais voltadas para o abastecimento dos mercados internos de seus países (MEDEIROS, 2011).

Paralelamente, as indústrias chinesas e indianas estão mais focadas em produzir com fins de exportação. Atualmente, mesmo tendo seu desenvolvimento industrial iniciado pelo processo de substituição de importações, a África do Sul também possui uma indústria mais voltada para o setor externo (SOUSA, YOSHINO, BIANCONI, 2011; VIEIRA, VERÍSSIMO, 2009).

Adicionalmente, existe a presença majoritária de commodities como principais produtos das plataformas de exportação de Rússia e Brasil. Diferente de China e Índia que exportam 
principalmente bens manufaturados e serviços relacionados à tecnologia da informação, respectivamente (SOUSA, YOSHINO, BIANCONI, 2011).

A África do Sul compartilha desses dois modelos, ou seja, sua plataforma de exportação envolve tanto commodities provenientes de mineração como bens manufaturados, tradicionalmente do setor automotivo (KAHN, 2011).

Ainda sobre exportações: é observado que as economias da Rússia e da China são as mais internacionalizadas, ou seja, possuem o maior valor de exportações em relação ao PIB. Além disso, Rússia, China e Brasil têm apresentado consecutivos saldos positivos em suas balanças comerciais. Contrariamente, Índia e África do Sul costumam apresentar déficit em suas respectivas balanças comerciais (SANTOS, 2010).

Ao se avaliar o risco geral desses países para investimentos, também é válido observar como seus governos atuam. Resumidamente, China e Rússia apresentam governos com regimes autoritários. Enquanto isso, África do Sul, Brasil e Índia possuem regimes de governo mais democráticos (ARMIJO, 2007, PAUTASSO, 2010).

Estrin e Prevezer (2010) observaram, nos países do BRIC somente, alguns fatores determinantes para a entrada de novas firmas como, por exemplo, infraestrutura, acesso a crédito, direito de propriedade e o enforcement dos contratos e depois avaliaram como as correntes de ação formais e informais atuavam dentro de cada um desses elementos. $\mathrm{Na}$ China e na Índia, os autores encontraram que as estruturas formais necessárias para o surgimento de novas firmas ainda são incipientes, fato que leva os agentes (incluindo os governos) a atuarem de maneira informal (ou menos formal) para contornar esses problemas estruturais de seus países. Por outro lado, no Brasil e na Rússia, as estruturas formais preparadas para o ambiente de negócios do país são, no geral, melhores que as estruturas dos outros dois países, mas as interações informais entre os agentes acabam por minar o desempenho dos negócios. Como exemplo dessas interações informais que causam certo prejuízo tem-se a corrupção e o trabalho informal.

Dados os objetivos desse trabalho, também é necessário entender características gerais similares a todos os mercados acionários do grupo. 
Sobre a eficiência desses mercados, existem evidências de que os mesmos não conseguem antecipar seus risk ratings. Adicionalmente, esses mercados também possuem problemas com informação privilegiada e disclosure insuficiente (HAMMOUDEH et al., 2012).

Também existe o fato de que os mercados acionários desses países não representam a principal fonte de financiamento para as empresas. Além disso, existe uma presença relevante do Estado no controle do capital das principais empresas que compõem suas bolsas de valores (SOUSA, YOSHINO, BIANCONI, 2011).

Outra característica que tem sido verificada é que, em média, a evolução do preço do petróleo parece explicar significativamente a evolução dos mercados acionários de Brasil, China e Rússia (ONO, 2011; RANGEL, 2012). Posto isso, é possível argumentar que essa commodity possui uma importância especial para esses países, como integrante dos principais produtos exportados ou importados.

Bao (2009), ao avaliar empresas dos mercados acionários somente do BRIC, encontrou que parcela relevante das empresas apresentava altas taxas de crescimento de seus ativos totais, porém não foi observada uma melhora significativa em seus indicadores de liquidez e rentabilidade. Assim, existem indícios que demonstram a possibilidade de que essas empresas crescem, mas não necessariamente têm melhorado sua saúde financeira. Nesse trabalho, o autor também encontrou que os resultados contábeis estão significativamente relacionados com os retornos das ações dessas empresas, demonstrando certa relevância da informação contábil nesses mercados.

Chittedi (2009), estudando somente o BRIC, encontrou evidências de que os mercados acionários desses países também estão cada vez mais integrados tanto no contexto global (cointegrados com os mercados dos países que compõem a OECD) como regional, demonstrando, em média, uma maior sensibilidade ao contexto regional.

Maiores detalhes sobre a integração entre os mercados acionários (e suas implicações) são apresentados nas subseções 2.2 e 2.3 .

Assim, é crescente a integração econômica (que inclui a integração entre os mercados acionários) entre o grupo, sendo uma consequência do aumento do comércio entre esses países na última década. 
Para analisar a evolução do comércio entre os países do grupo na última década, são apresentadas as tabelas 5 e 6 que versam sobre as exportações em 2001 e em 2011, respectivamente. No geral, o comércio entre os BRICS cresceu, principalmente quando se compara as colunas "BRICS" das duas tabelas. Desse crescimento, merecem destaque os aumentos das exportações de África do Sul, Brasil e Índia para a China. Em termos de participação relativa nas exportações, percebe-se que a China é o país menos dependente do comércio entre os BRICS (vide coluna "BRICS" das tabelas 5 e 6). Por outro lado, a África do Sul se mostra a mais dependente, principalmente em relação à China.

Tabela 5 - Participação relativa nas exportações do país de origem em 2001 (em \%)

\begin{tabular}{|l|c|c|c|c|c|c|}
\hline Origem & $\begin{array}{c}\text { África do } \\
\text { Sul }\end{array}$ & Brasil & China & Índia & Rússia & BRICS \\
\hline África do Sul & $\mathrm{X}$ & 0,96 & 2,75 & 2,98 & 0,16 & 6,86 \\
\hline Brasil & 0,73 & $\mathrm{X}$ & 3,26 & 0,49 & 1,89 & 6,37 \\
\hline China & 0,39 & 0,51 & $\mathrm{X}$ & 0,71 & 1,02 & 2,63 \\
\hline Índia & 0,74 & 0,53 & 2,10 & $\mathrm{X}$ & 1,91 & 5,29 \\
\hline Rússia & 0,01 & 0,19 & 5,60 & 1,12 & $\mathrm{X}$ & 6,92 \\
\hline
\end{tabular}

Fonte: UNCTAD (2013). Elaborada pelo autor.

Tabela 6 - Participação relativa nas exportações do país de origem em 2011 (em \%)

\begin{tabular}{|l|c|c|c|c|c|c|}
\hline Origem & $\begin{array}{c}\text { África do } \\
\text { Sul }\end{array}$ & Brasil & China & Índia & Rússia & BRICS \\
\hline África do Sul & $\mathrm{X}$ & 1,22 & 25,15 & 8,73 & 0,49 & 35,60 \\
\hline Brasil & 0,66 & $\mathrm{X}$ & 17,31 & 1,25 & 1,65 & 20,86 \\
\hline China & 0,70 & 1,68 & $\mathrm{X}$ & 2,66 & 2,05 & 7,09 \\
\hline Índia & 1,43 & 1,79 & 5,55 & $\mathrm{X}$ & 0,63 & 9,39 \\
\hline Rússia & 0,02 & 0,44 & 7,26 & 1,00 & $\mathrm{X}$ & 8,73 \\
\hline
\end{tabular}

Fonte: UNCTAD (2013). Elaborada pelo autor.

As tabelas 7 e 8 analisam a evolução das importações. Também é possível perceber o crescimento do comércio entre os países do grupo por essas tabelas. Basicamente, os mesmos padrões nas exportações, identificados nas tabelas 5 e 6, são encontrados nas importações. Com análise das tabelas de 5 a 8 , fica visível a importância da China para o resto do grupo. Entretanto, a China é o país menos dependente do grupo.

Tabela 7 - Participação relativa nas importações do país destino em 2001 (em \%)

\begin{tabular}{|l|c|c|c|c|c|c|}
\hline Destino & $\begin{array}{c}\text { África do } \\
\text { Sul }\end{array}$ & Brasil & China & Índia & Rússia & BRICS \\
\hline África do Sul & $\mathrm{X}$ & 2,38 & 3,65 & 0,85 & 0,14 & 7,02 \\
\hline Brasil & 0,51 & $\mathrm{X}$ & 2,39 & 0,98 & 0,84 & 4,71 \\
\hline China & 0,48 & 0,96 & $\mathrm{X}$ & 0,70 & 3,27 & 5,41 \\
\hline Índia & 2,31 & 0,72 & 4,86 & $\mathrm{X}$ & 1,84 & 9,72 \\
\hline Rússia & 0,10 & 2,18 & 4,83 & 1,51 & $\mathrm{X}$ & 8,62 \\
\hline
\end{tabular}

Fonte: UNCTAD (2013). Elaborada pelo autor. 
Tabela 8 - Participação relativa nas importações do país destino em 2011 (em \%)

\begin{tabular}{|l|c|c|c|c|c|c|}
\hline Destino & $\begin{array}{c}\text { África do } \\
\text { Sul }\end{array}$ & Brasil & China & Índia & Rússia & BRICS \\
\hline África do Sul & $\mathrm{X}$ & 1,36 & 11,60 & 3,28 & 0,15 & 16,39 \\
\hline Brasil & 0,40 & $\mathrm{X}$ & 14,49 & 2,69 & 1,30 & 18,88 \\
\hline China & 1,84 & 3,00 & $\mathrm{X}$ & 1,34 & 2,32 & 8,50 \\
\hline Índia & 1,46 & 0,80 & 12,16 & $\mathrm{X}$ & 0,95 & 15,37 \\
\hline Rússia & 0,12 & 1,53 & 15,01 & 0,78 & $\mathrm{X}$ & 17,45 \\
\hline
\end{tabular}

A dinâmica funciona da seguinte forma: a China é o componente que integra o grupo, estando entre os principais parceiros comerciais dos outros países tanto nas exportações como nas importações. Assim, os outros quatro países possuem uma dependência significativa da China, mas a recíproca não acontece. Entre os outros países as relações comerciais também não têm sido significativas. Essa configuração de integração econômica do BRICS pode ser resumida na Figura 1. Portanto, para cada país, ao se dividir o valor da importação da China pelo valor total das importações e o valor das exportações para a China pelo valor total das exportações, a China é:

- O principal destino das exportações da África do Sul;

- A principal origem das importações da África do Sul;

- O principal destino das exportações do Brasil;

- $\mathrm{O} 2^{\circ}$ maior em exportações para o Brasil;

- $\quad \mathrm{O} 2^{\circ}$ maior importador da Rússia;

- A principal origem das importações da Rússia;

- $\quad$ O $3^{\circ}$ maior importador da Índia; e

- A principal origem das importações da Índia. 


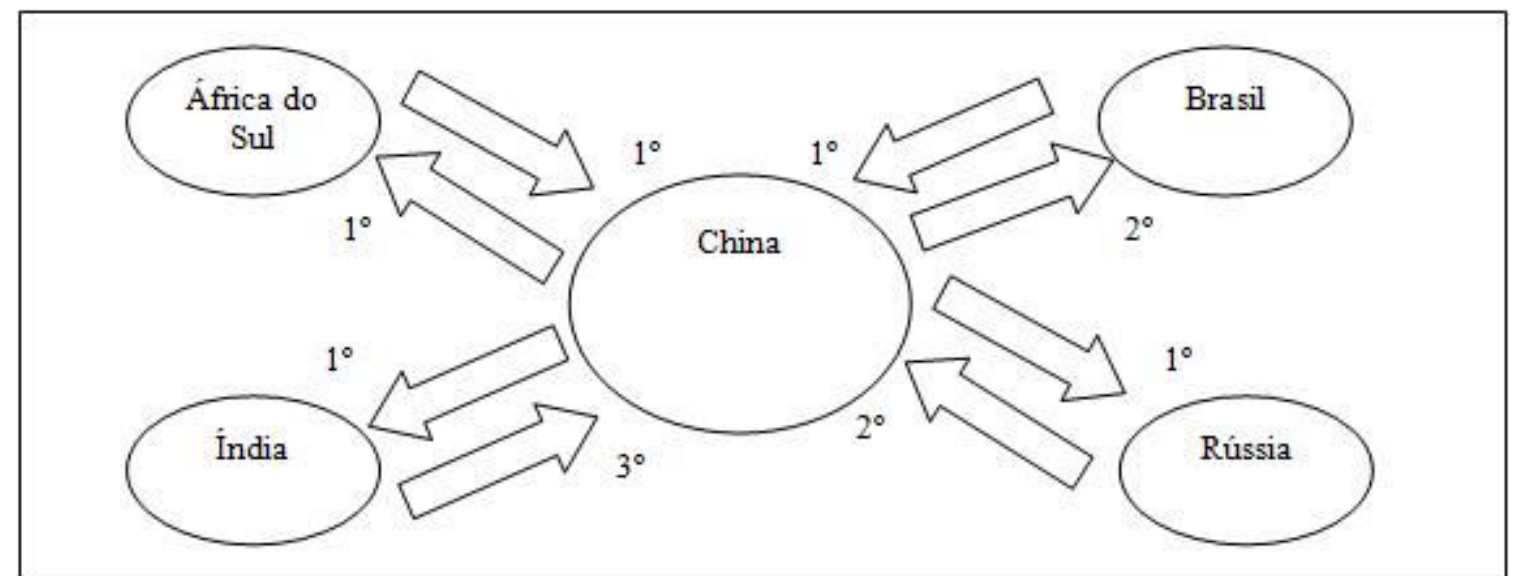

Figura 1 - Importância da China para o comércio internacional dos outros países do BRICS em 2011 FONTE: CIA, 2012. Elaborada pelo autor.

Os principais parceiros da China são Estados Unidos, Hong Kong, Japão e Coréia do Sul.

A China também responde por quase metade da economia do grupo, sendo a fonte de dinamismo do grupo e o elo comercial entre os outros países do BRICS (SANTOS, 2010). Portanto, intuitivamente, é como se a China integrasse todo o grupo por meio de seu comércio.

Colocadas as características gerais que ajudam a definir o que o grupo representa como um todo, é necessário pontuar alguns fatores específicos de cada país que ajudam a explicar a ascendência do grupo desde a década de 1990. Também é preciso levantar as restrições potenciais para a ascensão de cada país que ainda não foram citadas. Por fim, é necessário apresentar algumas características peculiares a cada mercado acionário que também servirão de base para a interpretação dos resultados dos testes desse estudo.

\subsection{1 África do Sul}

Desde o começo da década de 1990, a África do Sul tem passado por diversas mudanças estruturais e esse processo de mudança teve como ápice o fim do regime de segregação racial apartheid.

Além da segregação oficial entre brancos e negros, o país experimentava uma típica situação de isolamento internacional, com uma postura protecionista, câmbio fixo, e diversas restrições ao capital estrangeiro e ao investimento no exterior (FEDDERKE, 2002; BROOKS, DAVIDSON, FAFF, 1997). 
Entretanto, aconteceu um aumento significativo da presença do capital estrangeiro no país após o processo de abertura econômica nos anos 1990 que também envolveu uma reestruturação de seu mercado acionário (BASKARAN, MUCHIE, 2008).

Historicamente, a África do Sul tem como carros-chefes de exportação produtos oriundos de atividades de mineração. E uma vez que existe uma maior presença de investimento direto estrangeiro proveniente principalmente de empresas transnacionais da Europa, o setor automotivo também tem se desenvolvido, sendo, inclusive, parcela relevante na plataforma de exportações (KAHN, 2011; FEDDERKE, 2002).

Também vale ressaltar o pioneirismo e liderança do país na produção de combustível sintético a partir de carvão, principalmente para consumo interno, fato que ajuda a diminuir a dependência de petróleo do país (BASKARAN, MUCHIE, 2008).

Com a expansão da indústria, o país deixou de ter uma economia baseada unicamente em setores com uso intensivo de mão-de-obra pouco qualificada e passou a incluir setores intensivos em capital e com mão-de-obra altamente qualificada, configurando um relativo progresso tecnológico. E mesmo quando se trata de mão-de-obra pouco qualificada, existe um alto custo para as empresas devido à complexa legislação trabalhista do país, contribuindo para a queda da lucratividade e para a estagnação do crescimento do setor de mineração (KAHN, 2011; EDWARDS, 2001).

Problemas como: maior demanda por mão-de-obra altamente qualificada, declínio dos setores de mineração, investimento insuficiente em educação (e qualificação profissional), alto custo da mão-de-obra, patamar elevado das taxas de juros, aumento das importações e fim do protecionismo às empresas do país ajudam a explicar o problema de desemprego que a África do Sul vem enfrentando. Além disso, com o fim do controle rígido do câmbio e com o aumento das exportações e importações, o país também ficou mais vulnerável a choques externos (FRANKEL, 2007; EDWARDS, LAWRENCE, 2006; EDWARDS, 2001).

Diante desse cenário, a África do Sul observa baixas taxas de crescimento e, por ser economicamente o menor dos BRICS, pode ser categorizada como o outlier do grupo. Adicionalmente, o país possui graves problemas como: fraude, lavagem de dinheiro, AIDS e pobreza (NAYYAR, 2008; ROSSOW, WATT, MALAN, 2002). 
Seu mercado de ações é caracterizado por um baixo nível de governança corporativa. Isso fica visível quando se observa a propriedade altamente concentrada por grupos familiares, a pouca quantidade de empresas com grande parte da capitalização do mercado e a presença mínima de grupos negros no controle. Assim, os investidores estrangeiros acabam atuando fora da bolsa de valores. Apesar desses problemas, há indícios de que o desenvolvimento de seu mercado acionário está correlacionado com o crescimento econômico de longo prazo do país (ENISAN, OLUFISAYO, 2009, ROSSOW, WATT, MALAN, 2002).

Contudo, esse país é a principal potência do continente africano e seu crescimento econômico possui impacto significativo no crescimento da África. Também é o principal investidor em outros países da África, exercendo também liderança política no continente, além de contribuir para a transferência de tecnologia e para as iniciativas de cooperação econômica dentro da África. E com essa importância estratégica, a África do Sul também tem atraído investimentos da China, país que absorve grande parte de suas exportações, além de ter aumentado suas exportações para Índia e ter fechado acordos de cooperação no setor de agroprocessamento com o Brasil, possuindo, portanto, um papel relevante na dinâmica do grupo (KAHN, 2011; ARBORA, VAMVAKIDIS, 2005).

\subsubsection{Brasil}

Desde o fim da década de 1980 até meados da década de 2000, o Brasil passou por processos de abertura comercial e financeira e também consolidou seu processo de estabilização da economia.

Antes do processo de estabilização, iniciado com a implementação do Plano Real, o país sofria com uma elevada inflação inercial que travava a expansão da atividade de crédito pelo setor privado, limitando a taxa de investimento do país. Assim, o crescimento da produtividade geral era restrito, justificando o baixo crescimento econômico. Entretanto, mesmo com a consolidação do processo de estabilização econômica, o crescimento econômico brasileiro ainda é modesto (HIRAKAWA, AUNG, 2011; GREMAUD, VASCONCELLOS, TONETO JÚNIOR, 2009).

A abertura comercial começou desde 1988, no governo Sarney, com o fim de medidas protecionistas que acabaram expandindo a participação das importações no mercado interno do país. Essa abertura relativamente rápida, de início, prejudicou a indústria nacional que não tinha condições francas de competir com os produtos importados tanto em termos de custo 
como em termos de qualidade, fato que também ajudou a reduzir possíveis pressões inflacionárias. Posteriormente, houve um processo de modernização dos setores econômicos brasileiros. Por outro lado, o processo de abertura financeira começou em 1990 e criou a possibilidade de lançamento de títulos no exterior, acesso direto dos investidores institucionais aos mercados de renda fixa e variável do Brasil e liberalização do ingresso/saída de recursos externos. Com isso, houve um crescimento significativo do investimento direto estrangeiro no país, também explicado pelo amplo processo de privatização que aconteceu nessa época e, consequentemente, houve uma perda de autonomia do governo na condução das políticas econômicas internas devido a uma maior vulnerabilidade aos choques externos (GREMAUD, VASCONCELLOS, TONETO JÚNIOR, 2009; VIEIRA, VERÍSSIMO, 2009).

Considerando a substituição de importações como o principal objetivo para o desenvolvimento industrial, a indústria nacional tende a focar no abastecimento do mercado interno e não em produzir para exportar. Portanto, somando-se a esse fato a riqueza de recursos naturais brasileira e o histórico de país agroexportador, estão apresentados os principais fatores que explicam o fato das exportações consistirem fundamentalmente de commodities primárias como soja, minério de ferro e petróleo bruto. Além disso, na última década, houve uma diversificação no que diz respeito aos países compradores dos produtos brasileiros, incluindo mais países não desenvolvidos e contribuindo para a cooperação Sul-Sul (MEDEIROS, 2011; GREMAUD, VASCONCELLOS, TONETO JÚNIOR, 2009).

Na última década, além de consolidar o processo de estabilização da economia (com o tripé ajuste fiscal, câmbio flutuante e metas de inflação), o governo também conseguiu melhorar os indicadores de solvência, revertendo o processo de crescimento da dívida externa e mudando o perfil da dívida pública (diminuindo a quantidade de títulos públicos atrelados ao dólar e à Selic). Também são fatores da estabilização: o alto preço das commodities, o crescimento econômico mundial e a desoneração tributária parcial do setor exportador que acabou levando à geração de superávit comercial e ao aumento das reservas internacionais. Diante desse novo cenário, houve uma queda gradual no risco-país e, com um menor risco e com altas taxas de juros reais, o investimento estrangeiro continuou a crescer (GREMAUD, VASCONCELLOS, TONETO JÚNIOR, 2009).

Os principais problemas da economia brasileira são: os altos níveis das taxas de juros, os baixos níveis de poupança, desigualdade social, carga tributária elevada, alto custo da mãode-obra e baixo nível de investimento. Com esses problemas, também é nítida a necessidade 
de uma reforma tributária e previdenciária no país (ESTRIN, PREVEZER, 2010; SANTOS, 2010; GREMAUD, VASCONCELlOS, TONETO JÚNIOR, 2009). Além disso, recentemente, surgiram novos problemas a respeito do controle da inflação.

Somente na última década, o mercado acionário brasileiro vem ganhando destaque como alternativa de financiamento para as empresas. Parte desse movimento se deve às privatizações e aos novos meios de ingresso de capital estrangeiro. Entretanto, alguns fatores ainda limitam o desenvolvimento desse mercado. A maioria do controle de capital das empresas se resume ao Estado ou a grupos familiares. Fora isso, existem outros fatores que desincentivam o investimento de acionistas minoritários: a internacionalização do sistema financeiro que amplia a janela de opções para o investidor e a alta rentabilidade do mercado de renda fixa brasileiro (SOUSA, YOSHINO, BIANCONI, 2011; GREMAUD, VASCONCELLOS, TONETO JÚNIOR, 2009; DA SILVEIRA, 2004).

Adicionalmente, a disponibilidade de crédito de longo prazo por um custo relativamente mais baixo, subsidiado pelo governo via BNDES, também é um fator que restringe o desenvolvimento do mercado de ações brasileiro. E os bancos privados acabam atuando na concessão de créditos de curto a médio prazo (ASSAF NETO, 2008; ANDREZZO, LIMA, 2007).

Por esses e outros motivos, o mercado de ações brasileiro, comparado com os mercados de países desenvolvidos, ainda possui poucas empresas, propriedade concentrada e poucos investidores na condição de pessoa física.

Regionalmente, o país tem uma significativa integração econômica com os países também componentes do Mercosul.

\subsubsection{China}

Desde a criação das Zonas Econômicas Especiais (ZEEs) em 1978, a China vem abrindo sua economia para o capital estrangeiro, tornando-se cada vez mais uma economia de mercado. Entretanto, foi somente em meados da década de 1990 que o país começou a se destacar por seu desempenho econômico, com altas taxas anuais de crescimento econômico (HIRAKAWA, AUNG, 2011; ANDRADE, 2006).

Parte dessa ascensão tem como fatores uma série de ações governamentais que acabaram colocando a China como a segunda maior economia do mundo. Em primeiro lugar, pode-se 
destacar o investimento público em infraestrutura, principal indutor da produtividade geral, focando inicialmente na indústria pesada, principalmente na produção de aço, e depois em outros setores estratégicos, inclusive os relacionados com a segurança nacional. O governo ainda trabalhou com uma taxa de juros baixa, além de uma política fiscal expansionista e uma taxa de câmbio competitiva (totalmente controlada pelo governo). Também contribuíram para esse processo de crescimento: a centralização política e a liderança das empresas estatais (MEDEIROS, 2011).

Com o câmbio rígido e desvalorizado em termos reais, o governo chinês mantém uma política favorável às exportações e à atração do capital estrangeiro, além de proporcionar uma relativa proteção contra choques externos na economia chinesa (VIEIRA, VERÍSSIMO, 2009, ANDRADE, 2006; DE PAULA, FERRARI FILHO, 2006).

Adicionalmente, desde quando entrou na Organização Mundial do Comércio em 2001, o governo chinês oficializou seu objetivo de explorar mercados menos tradicionais a baixos preços como África do Sul, Brasil, México e Argentina. Esse fato também contribuiu para que a economia chinesa sofresse um impacto negativo menor durante a crise financeira de 2008 (BAUMANN, 2009; CHILD, RODRIGUES, 2005; SAUVANT, 2005).

Outro fator importante para o crescimento chinês é a sua numerosa população. Com o cenário de extrema pobreza no campo e o investimento público centrado nas cidades, grande parte da população rural (ainda maioria da população) começou a migrar para as cidades. Nesse movimento, com uma grande parte da população saindo da pobreza extrema presente no campo, elevou-se a renda e o potencial de consumo do país, configurando um grande mercado doméstico que ajudou a impulsionar o desenvolvimento das indústrias e o aumento das importações de commodities para atender a essa significativa demanda incremental. A indústria também se beneficiou da então nova e extensa reserva de trabalho que acaba se materializando em um baixo custo de mão-de-obra que acabou aumentando o valor adicionado de empresas transnacionais que se estabeleciam na China e, consequentemente, a produtividade do país (MEDEIROS, 2011).

Contudo, a mão-de-obra de baixo custo não é considerada o único fator para os investimentos estrangeiros diretos na China. Dado o grande potencial de consumo de um mercado doméstico altamente populoso, outro fator para a atração de investimentos seria o fato de existirem 
vários mercados em franca expansão dentro da China como o mercado de artigos de luxo, por exemplo (HIRAKAWA, AUNG, 2011).

A indústria chinesa também se beneficiou do novo modelo de produção modularizada que envolve terceirização de tecnologias e alta importação de partes e componentes (MEDEIROS, 2006).

Nessa nova configuração, a produção de um determinado bem manufaturado termina após passar por diversas etapas em vários países, estabelecendo uma cadeia de valor global em que países como Brasil e Rússia fornecem commodities primárias para que países industrializados da Ásia fabriquem os componentes. Depois outros países somente montam os produtos que geralmente são projetados em escritórios dos países desenvolvidos e, a partir disso, esses produtos são distribuídos para todo o mundo.

$\mathrm{O}$ fato de o sistema bancário e o mercado acionário não serem eficazes o suficiente no fornecimento de crédito para a iniciativa privada impulsiona o crescimento da poupança privada na China (ESTRIN, PREVEZER, 2010). Assim, os chineses têm preferido recorrer às suas próprias economias a contratar fornecimento de crédito no mercado financeiro.

Assim, por todos esses fatores apresentados, a China observou um aumento significativo em sua taxa de investimento que depois se materializou em altas taxas de crescimento econômico.

Com esse mercado interno em expansão, a China aumentou suas importações tanto de países desenvolvidos como de emergentes, sendo hoje elemento fundamental no dinamismo da economia mundial e, inclusive, transformando-se no principal pilar do grupo BRICS, exercendo o papel de grande parceiro comercial dos outros quatro países e respondendo por quase metade do PIB do grupo (NIKKINEN, SALEEM, MARTIKAINEN, 2011; SANTOS, 2010).

Além dessa representatividade econômica, a China possui certo destaque político desde quando obteve o direito de voto com poder de veto no Conselho de Segurança da ONU.

Dentre as restrições potenciais da economia chinesa, têm-se a produtividade declinante do investimento e a incerteza sobre a sustentabilidade de seu sistema político, essa última também tem explicado grande parte do risco do mercado de capitais chinês (HAMMOUDEH et al., 2012; NAYYAR, 2008). 


\subsection{4 Índia}

A Índia tem observado um grande crescimento econômico tanto no âmbito mundial quanto no âmbito dos BRICS. O setor de serviços está entre os propulsores desse crescimento, mais especificamente serviços da área de tecnologia da informação como, por exemplo, desenvolvimento de softwares e soluções de engenharia para indústrias de vários lugares do mundo (BIGGEMANN, FAM, 2011; FIDRMUC, KORHONEN, 2010).

Outro indutor do crescimento indiano é a sua demanda interna. Assim como a China, a Índia é um país altamente populoso, fato que faz com que o consumo seja sempre alto, estimulando o investimento e o desenvolvimento industrial para atender a esse consumo. Inclusive, existem previsões de que a população indiana passará a chinesa daqui a alguns anos (MEDEIROS, 2011).

Assim, o rápido desenvolvimento do setor de serviços, principalmente os serviços de alta tecnologia, foi crucial para o crescimento do país (BOSWORTH, 2007).

Esse desenvolvimento começou com reformas estruturais que se estenderam de 1985 a 1990. E em 1991, a liberalização comercial e financeira impulsionou ainda mais o desenvolvimento da indústria indiana e a inserção internacional do país. Dentro das reformas estruturais, ocorreu a liberação gradual dos licenciamentos industriais e das licenças de importação, inclusive da importação de itens estratégicos que antes era de direito exclusivo do governo, além de estímulos à exportação, contando com uma maxidesvalorização do câmbio e uma minirreforma tributária que abrangeu deduções e isenções sobre o valor adicionado dos insumos produzidos no país ou importados. E, por fim, houve um processo de descentralização política em que os estados ganharam maior autonomia. Assim, pode-se afirmar que o setor público desempenhou um papel central ao passar parte de suas responsabilidades para o setor privado e manter a gestão de setores menos atrativos para a iniciativa privada (VIEIRA, VERÍSSIMO, 2009; CHENG et. al, 2007; NASSIF, 2006).

O processo de abertura englobou privatizações, liberalização do investimento direto estrangeiro, desregulamentação bancária, simplificação dos mecanismos de determinação da taxa de juros, simplificação do processo de abertura de capital e permissão para que investidores estrangeiros pudessem investir nas companhias abertas indianas (VIEIRA, VERÍSSIMO, 2009). 
O país também concentra investimentos em países como Estados Unidos e Rússia, com fins de adquirir acesso a tecnologias avançadas e a recursos minerais, respectivamente. E a partir dessas redes de valor e parcerias comerciais, é possível afirmar que a economia indiana está altamente integrada com a economia mundial, fato que também é evidenciado com a integração de seu mercado de capitais aos principais mercados do mundo (SANTOS, 2010; JAYARAM, PATNAIK, SHAH, 2009).

Com isso, a Índia desenvolveu uma economia diversificada, abrangendo desde a agricultura tradicional até o agroprocessamento moderno e os serviços de alta tecnologia. E para os serviços de alta tecnologia, a Índia dispõe de profissionais altamente qualificados e disciplinados que desempenham o modelo de gestão ocidental, utilizando, inclusive, o inglês como idioma dos negócios. Esses fatos acabam facilitando a inserção internacional do país (FESTEL, 2008; CHENG et al., 2007; REDDY, 2005).

Entretanto, essa força de trabalho altamente qualificada, mesmo produzindo em média $50 \%$ do PIB indiano, responde por cerca de $1 / 4$ da força de trabalho do país enquanto cerca de $60 \%$ da população economicamente ativa ainda está na agricultura tradicional e geralmente vive em situação de pobreza. Esse fato acaba revelando a propagação limitada da educação no país e consequentemente traduz o alto nível de desigualdade social existente (CHENG et al., 2007, NAYYAR, 2008).

Outro gargalo importante existente na Índia é a sua infraestrutura incipiente que ainda demonstra insuficiência no oferecimento de serviços básicos para a população como energia elétrica e água potável (NAYYAR, 2008; ARMIJO, 2007; CHENG et al, 2007).

\subsubsection{Rússia}

Diferente dos outros países, a Rússia não é consensualmente vista como um país emergente no sentido mais estrito do termo e sim como um país que tenta manter parte da herança da antiga União Soviética (PAUTASSO, 2010).

Depois da crise russa de 1998, a economia russa tem passado por diversas reformas e transformações que trouxeram relativa estabilidade.

Considerando o fato de que as exportações constituem elemento fundamental em sua economia e grande parte dessas exportações está concentrada somente em petróleo e gás natural, é possível inferir que a economia russa é especialmente vulnerável a flutuações no 
preço do petróleo (CHENG et al, 2007). Inclusive, existem evidências de uma associação inversa significativa entre a evolução do preço do petróleo e a evolução do câmbio russo (SOUSA, YOSHINO, BIANCONI, 2011).

Assim, parte do crescimento econômico russo na última década também pode ser explicada pela valorização do petróleo (DE PAULA, FERRARI FILHO, 2006).

Entretanto, esse não é o único fator que explica a ascensão recente da economia russa que começou em 1999. A Rússia passou por um intenso processo de ajuste fiscal em que a sua conta fiscal passou a ser sistematicamente superavitária, semelhante ao que acontece com a sua balança comercial. Com uma geração de divisas proveniente do alto preço do petróleo e um consequente aumento das exportações, o país reduziu seu endividamento externo e acumulou um grande montante de reservas internacionais, oferecendo, assim, relativa proteção diante de uma possível crise. E o aumento da produção de petróleo, a desvalorização da moeda e uma queda nas taxas de juros são fatores que alavancaram a produção de outros setores industriais e de serviços. Dado que o modelo de industrialização russo é baseado essencialmente no processo de substituição de importações, o recente crescimento industrial ajudou a abastecer o mercado interno que também foi beneficiado pelo fato do salário crescer, em média, mais que o PIB (VIEIRA, VERÍSSIMO, 2009; DE PAULA, FERRARI FILHO, 2006; OWEN, ROBINSON, 2003).

Contudo, a Rússia ainda apresenta certas restrições que acabam limitando a percepção de maiores taxas de crescimento. Com um mercado de capitais relativamente pequeno e um sistema bancário ineficiente, dominado por dois bancos estatais, existe falta de confiança no setor de crédito, o que acaba travando a expansão desse setor e o aumento da taxa de investimento do país (CHENG et al, 2007).

Essa falta de confiança nos setores de crédito e de investimento também pode ser explicada pelo histórico relevante de inflação do país. Além disso, muitos dos investimentos russos têm sido direcionados para fora do país, principalmente para os Estados Unidos e outros países da Comunidade dos Estados Independentes (CEI) dada a existência de altos impostos e constrangimentos regulatórios no país. E o alto nível de corrupção dentro do governo, proveniente das múltiplas interpretações que podem surgir da legislação atual, gera uma falta de confiança generalizada nas instituições russas. Parte desses problemas foi solucionada 
depois de reformas em 2000 e 2002 que buscavam maior transparência para o país (ESTRIN, PREVEZER, 2010; PAUTASSO, 2010; VIEIRA, VERÍSSIMO, 2009; SAUVANT, 2005).

Assim como a China, a Rússia também possui voto com poder de veto no conselho de segurança da ONU. Outra fonte de influência da Rússia seria o seu elevado desenvolvimento nuclear militar. Do ponto de vista político, também é válido ressaltar que grande parte do trabalho de diplomacia da Rússia tem sido focada na sua integridade territorial (PAUTASSO, 2010).

\subsection{Integração financeira entre os países}

Problemas como crises financeiras mundiais e instabilidade do sistema financeiro global trazem à tona a emergência de profunda investigação sobre as causas e implicações de fenômenos como a integração financeira entre os países, a transmissão de choques entre mercados financeiros e o efeito contágio. Some-se a isso o fato de que um maior conhecimento sobre esses fenômenos pode contribuir para a otimização de portfólios que trabalham com a possibilidade de diversificação internacional. Essa e a próxima subseção apresentarão os principais conceitos e descobertas da literatura sobre esses fenômenos.

Apesar de não existir uma definição universal sobre o que significa integração financeira entre os países, Yu et. al (2010) argumentam que esse fenômeno compreende abertura financeira, movimento livre de capital entre os países e serviços financeiros integrados. A integração financeira também pode ser entendida como um subconjunto da integração econômica (KEARNEY, LUCEY, 2004).

Segundo Gremaud et. al (2009, p. 561), a integração econômica pode ser entendida como "um processo de diminuição de discriminações entre países diferentes; essas discriminações afetam as relações econômicas entre esses Estados Nacionais e entre essas discriminações estão as proibições ou dificuldades de comercializar, de circular, de investir etc. entre os países".

Para a elaboração da conjectura do presente estudo, é necessário apresentar o princípio da similaridade de preferências da teoria pelo lado da demanda (ou TLD) que contribui para a explicação da integração econômica e, por conseguinte, da integração financeira.

Dentro da TLD, que faz parte do corpo de teorias do comércio internacional, Linder (1961) acrescenta que países que possuem demandas com estruturas de preferências relativamente 
iguais tendem a desenvolver um significativo comércio entre eles. Também é pressuposto que para que essas demandas tenham essas similaridades de preferências, os países devem possuir um grau similar de desenvolvimento. Por fim, tem-se que as exportações correspondem a produtos que já são bastante consumidos no país de origem porque a similaridade das preferências aumenta a chance de que esses produtos repitam o sucesso em outro país que possui uma demanda com as mesmas preferências.

Dessa forma, é possível argumentar que países que possuem demandas com estruturas de preferências homogêneas tendem a desencadear um processo de integração econômica e, consequentemente, de integração financeira.

A partir disso, fica visível que para a investigação das causas da integração financeira é necessário estudar a influência da economia real. E, por isso, diversas pesquisas sobre integração financeira têm focado nesse aspecto.

Dentre essas pesquisas, Johnson e Soenen (2003), analisando os comovimentos dos mercados de ações (uma proxy para integração financeira) de toda a América, encontraram que os maiores níveis de integração financeira compreendiam os mercados de Estados Unidos, Canadá e México que são integrantes do bloco de comércio comum NAFTA e, numa segunda análise, constataram que a intensidade e a magnitude da relação comercial com os Estados Unidos tinham um forte efeito positivo nos comovimentos dos mercados. Em um trabalho similar, Aggarwal e Kiaw (2005) encontram cointegração entre as séries de retorno dos mercados de ações de Estados Unidos, Canadá e México somente no período imediatamente posterior à celebração do acordo de criação do NAFTA.

Adicionalmente, existem evidências de que dependências comerciais bi ou multilaterais, estabelecidas com ou sem a formação de blocos de comércio comum, são importantes determinantes da integração financeira, ou seja, essas relações intensificam o fluxo de capital entre os países, impulsionam uma maior abertura financeira entre os mesmos e um desenvolvimento de seus respectivos mercados financeiros, com o objetivo de processar eficientemente esse fluxo incremental de capital (FRANKEL, ROSE, 1998; CALDERON, CHONG, STEIN, 2007).

Parte das relações encontradas nesses trabalhos pode sugerir que a proximidade geográfica seja um fator determinante para explicação da integração financeira, mas a ligação comercial 
e os esforços cooperativos entre os países parecem superar grandes distâncias, mostrando-se também importantes na explicação da integração financeira, uma vez que é encontrada influência significativa do mercado de capitais dos Estados Unidos nos mercados de seus grandes (e distantes) parceiros comerciais como Japão, Reino Unido e Alemanha (HAMAO, MASULIS, NG, 1990; BECKER, FINNERTY, TUCKER, 1992; THEODOSSIOU, LEE, 1993).

O avanço tecnológico na comunicação nos últimos 30 anos também foi um fator determinante, tornando os mercados internacionais mais eficientes tanto no processamento das transações entre os mercados como também proporcionando uma maior velocidade no fluxo de informação entre os agentes, além do maior acesso a informação por esses agentes (MASIH, MASIH, 2001).

Neste processo de integração financeira, existem processos subjacentes que funcionam como catalisadores dessa integração como, por exemplo, a liberalização comercial e financeira dentro dos países com fins de entrar efetivamente no mercado internacional. Essa separação entre comercial e financeira é desenvolvida aqui apenas para fins de uma análise mais profunda de seus componentes, mas, na realidade, esses dois processos acontecem simultaneamente, em diversos graus, dependendo das ações do governo do país. Assim, o que é determinante é o grau dessa liberalização.

A liberalização comercial, geralmente estabelecida dentro do âmbito da formação de blocos supranacionais, consiste basicamente da remoção, parcial ou total, das restrições domésticas em preços, além da redução, parcial ou total, de tarifas protecionistas que recaem sobre bens importados e da redução de subsídios a bens produzidos no próprio país e, por fim, tem-se a harmonia de estruturas legais e comerciais entre os países. A liberalização financeira inclui a redução, parcial ou total, dos controles sobre o capital estrangeiro e sobre a taxa de câmbio (de fixa para flutuante), além da desregulamentação dos mercados financeiros que busca a harmonização de padrões com o mercado internacional, permitindo maior participação estrangeira nos mercados domésticos (AGGARWAL, KIAW, 2005; KEARNEY, LUCEY, 2004; YU, FUNG, TAM, 2010).

Com essa liberalização (comercial e financeira), existe um alicerce formal criado pelos governos dos países que contribui para a construção de uma infraestrutura financeira que induz a integração financeira. Assim, acontece um desenvolvimento das bolsas de valores e 
dos mercados de títulos em geral por meio da criação de sistemas integrados de liquidação e custódia que viabilizam a realização de transações em tempo real com investidores no exterior, por exemplo. Esse desenvolvimento traz maior agilidade e redução dos custos de transação. Adicionalmente, essa nova configuração pode viabilizar a criação de novos instrumentos financeiros que permitirão aos agentes tomadores de recursos maior acesso ao capital estrangeiro por meio de securitização. Como exemplo desses instrumentos que viabilizam um mercado internacional, têm-se os American Depositary Receipts, os Global Depositary Receipts, os eurobonds e as euronotes. As principais câmaras de compensação dos mercados internacionais de títulos, fundamentalmente títulos de dívida, são a Euroclear, em Bruxelas, e a Cedel, em Luxemburgo (LIMA, LIMA, PIMENTEL, 2006; FORTUNA, 2010).

Como exemplo de um caso mais avançado de liberalização financeira, existe a unificação da moeda entre os países. Trabalhos como os de Rose e Engel (2002) e Kim et al. (2005) encontram evidências de que a introdução do Euro intensificou a integração dos mercados financeiros dos países integrantes da União Européia.

Dentro do grupo dos determinantes informais ou indiretos que induzem a integração financeira, existe a presença e expansão das empresas multinacionais (SECURATO, OLIVEIRA, 1998). Essas grandes empresas, inseridas em longas cadeias de valor, precisam movimentar, além de insumos e produtos, recursos financeiros entre os componentes dessas cadeias. Além disso, parte considerável dessas empresas são empresas do setor financeiro como bancos que mantêm a padronização de seus produtos e instrumentos financeiros por todas as suas unidades pelo mundo (YU, FUNG, TAM, 2010).

Outros agentes importantes nesse processo são os investidores institucionais. Investidores institucionais como os fundos soberanos têm conseguido acessar até mercados de capitais altamente regulados (PHYLAKTIS, RAVAZZOLO, 2005). Esses fundos mantêm um considerável fluxo de capital entre os países, influenciando o modus operandi dos mercados de capitais de vários países. Em alguns casos, esses fundos também são instrumentos de política econômica dos governos como no caso dos fundos soberanos. Exemplos de investidores institucionais são os fundos de pensão, fundos de hedge e, de certa forma, no contexto internacional, bancos centrais com grandes reservas cambiais (SUBACCHI, 2008).

Além da circulação de capital de curto prazo proveniente da ação conjunta desses agentes (multinacionais e fundos), é sabido que esses também são os principais agentes que 
promovem o investimento direto estrangeiro (IDE) em países emergentes e desenvolvidos que geralmente envolve um período de maturação maior, criando canais de financiamento de longo prazo, favorecendo uma maior integração financeira entre países desenvolvidos e emergentes (KAWAI, 2005).

Outro fator que influi negativamente na sincronia entre mercados é a capitalização dos mercados. Assim, quanto maior for o valor capitalizado no mercado de um país, mais influente será o mercado e, portanto, seus movimentos tendem a ser mais independentes dos movimentos dos mercados de outros países. Na literatura, esse fato tem sido observado principalmente no mercado de ações dos Estados Unidos em que os movimentos desse mercado parecem não ser significaticamente explicados pelos movimentos de outros mercados (EUN, SHIM, 1989; MASIH, MASIH, 2001).

Entretanto, a sincronia dos ciclos de negócios por si só não é suficiente para explicar todo o fenômeno de integração financeira. Esse argumento surge do fato de que os comovimentos dos mercados podem não captar totalmente o efeito dos fluxos de recursos e nem as causas dos mesmos (BUTTNER, HAYO, 2011).

Para consolidar o que já foi apresentado nesta subseção, é apresentada a seguinte equação sobre a evolução de um mercado de ações de um determinado país:

$$
I_{t}=a_{1} I_{t-1}+a_{2} G_{t-1}+\varepsilon_{t}
$$

Nessa equação, $I_{t}$ corresponde ao valor do índice que representa todo o mercado de ações em questão no instante t. Assim, a evolução de $I_{t}$ é explicada pelo seu valor passado $I_{t-1}$, por fatores internacionais passados $G_{t-1}$ e por um ruído $\varepsilon_{t}$ (KING, WADHWANI, 1990). O que os determinantes da integração financeira apresentados anteriormente fazem é aumentar a significância de $a_{2}$, aumentando a relevância de fatores internacionais, gerando uma estrutura de interdependência entre os mercados dos países integrados (BRACKER, DOCKING, $\mathrm{KOCH}, 1999)$. Como essa influência dos fatores internacionais se processa será assunto da próxima subseção quando serão estudados transmissão e contágio entre mercados financeiros.

Quando se analisam as implicações da integração financeira entre os países, existem evidências de que esse fenômeno induz o crescimento econômico dos países (LEVINE, ZERVOS, 1996; LEVINE, 2001; BEKAERT, HARVEY, LUNDBLAD, 2004). 
Uma das explicações para as evidências comentadas no parágrafo anterior seria baseada na alocação de capital. A integração financeira pressupõe o desenvolvimento de um mercado financeiro internacional no qual investidores podem investir segundo as melhores oportunidades que encontrarem pelo mundo, isto é, segundo o prêmio sobre o risco dos projetos de investimentos disponíveis, não se limitando às fronteiras de seu país de origem. Dessa forma, em tese, um país só receberá investimentos estrangeiros direcionados para setores em que tenha vantagens comparativas relevantes a nível mundial, maximizando o prêmio sobre o risco do investidor. Assim, esse país terá um novo aporte de capital em seus setores mais produtivos, alavancando a geração de riqueza segundo sua produtividade. Expandindo esse raciocínio para todos os países, é plausível o argumento de que a integração financeira gera uma alocação de capital pelo mundo mais eficiente que induz o aumento de produtividade e, consequentemente, o crescimento econômico dos países (UMUTLU, AKDENIZ, ALTAG-SALIH, 2010).

Entretanto, ainda dentro dessa linha de pensamento, quanto menor o número de setores com vantagens comparativas em um país, maior será a chance dos investidores retirarem seus investimentos desse país e direcioná-los para países que ofereçam melhores oportunidades, gerando uma evasão de capital do país em questão. Um movimento conjunto nessa direção geraria um efeito adverso na economia do país. Cabe acrescentar que o grau de integração financeira varia entre os países, dependendo também do período analisado (BEKAERT, HARVEY, 1995).

Continuando com o foco nesse mercado internacional promovido pela integração financeira: em uma visão mais ampla, cada país deixa de ser encarado como um mercado próprio e passa ser encarado como um ativo (SECURATO, OLIVEIRA, 1998). Assim, para o investidor em escala internacional, o risco sistemático deixa de ser o risco do mercado de capitais de seu país de origem e passa a ser o risco sistemático do mercado mundial de ativos-países. Dadas as oportunidades de diversificação internacional como as encontradas em Bruni et. al (1998), o risco sistemático do mundo tende a ser diferente dos riscos sistemáticos dos mercados dos países considerados isoladamente. E parte do risco sistemático do mercado do país pode acabar se tornando um risco específico daquele país que corresponderá, por exemplo, a seu risco político e a sua instabilidade macroeconômica, podendo ser mitigado com diversificação internacional (BEKAERT, 1995). 
Outra consequência da integração financeira seria que, em um cenário de livre mobilidade de capital entre os países, ativos com fluxos de caixa futuros idênticos e com graus de incerteza sobre esses fluxos idênticos, ou seja, com custos de capital idênticos, tendem a ser avaliados e precificados da mesma forma, possuindo preços idênticos mesmo quando instalados em diferentes países, demonstrando uma forte eficiência do mercado financeiro internacional. Essa consequência é conhecida na literatura como a "lei do preço único". Entretanto, a lei do preço único pode ser violada por um fenômeno conhecido como "viés do lar". Esse fenômeno compreende o fato de que os investidores tendem a investir mais em ativos do país onde residem, considerando o quanto a teoria considera como ótimo (KEARNEY, LUCEY, 2004).

Uma conseqüência negativa da integração financeira seria a geração de uma maior vulnerabilidade a crises financeiras mundiais (BEINE, COSMA, VERMEULEN, 2010). Considerando-se um caso extremo de um país "A" economicamente e financeiramente isolado, o valor do índice do mercado desse país variará somente conforme seus fluxos de capitais internos. Além do mais, esse mercado não sentirá nenhum efeito de uma crise proveniente do resto do mundo. Entretanto, a partir do momento em que o grau de integração financeira de "A" com outro país "B" deixa de ser zero, o mercado de capitais de "A" responderá a movimentos de "B" e vice-versa, como já comentado anteriormente. Se "B" entrar em crise, serão criadas inovações nos movimentos do índice de seu mercado que serão transmitidas para o mercado de $\mathrm{A}$ em uma magnitude que dependerá do grau de integração financeira existente entre os dois.

Dessa forma, quanto mais integrado ao sistema financeiro global, mais exposto a crises provenientes de outro país está o mercado analisado. E uma crise tende a aumentar a sincronia entre os mercados, posto que a tendência é de que todos se transformem em bear markets e apresentem conjuntamente uma queda aguda no valor de seus índices (LONGIN, SOLNIK, 2001). Esse fato também pode ser explicado pelo efeito contágio que será apresentado e discutido na próxima subseção.

Portanto, com uma estrutura de interdependência mais robusta entre os mercados de capitais, é reduzida a probabilidade de um choque de efeito assimétrico entre os países. Os efeitos de uma crise tendem a ser mais uniformes entre os mercados (UMUTLU, AKDENIZ, ALTAGSALIH, 2010). 
Outra consequência negativa direta seria a queda na atratividade do uso do recurso da diversificação internacional (PHYLAKTIS, RAVAZZOLO, 2005). Com a interdependência gerada pela integração financeira, existe um aumento nos comovimentos dos índices dos mercados de capitais. Dessa forma, será mais difícil encontrar ativos de diferentes países que tenham fluxos de caixa que se movam em direções opostas.

Esse maior dinamismo no fluxo de capital pode implicar em uma maior variabilidade da taxa de poupança dos países e pode, portanto, aumentar a variabilidade de sua taxa de investimento. Esse fato também pode trazer uma maior volatilidade para a taxa de juros do país, demandando do governo uma elaboração de sólidas políticas macroeconômicas que contenham o aumento dessa volatilidade, mantendo a estabilidade econômica e o desenvolvimento contínuo de seus projetos de investimento (PAGANO,2003).

No caso de uma integração financeira que conta com a unificação da moeda entre os países como acontece na União Européia, o risco de câmbio decorrente das transações entre esses países é anulado (FRATZCHER, 2002; BAELE et al, 2004).

É documentado pela literatura que existe um aumento da liquidez nos mercados domésticos proveniente do fluxo incremental de capital vindo de investidores estrangeiros que obtêm acesso ao mercado de capitais do país e, por conta dessa maior liquidez, é observada uma maior eficiência nesse mercado (BRACKER, DOCKING, KOCH, 1999).

Trabalhos como os de Kasa (1992), Longin e Solnik (1995) e Phylaktis e Ravazzolo (2002) revelam que os mercados de ações por todo o mundo têm apresentado ligações significantes e essas interdependências parecem ficar mais robustas com o tempo, movidas pelo maior desenvolvimento desses mercados.

A detecção de vetores de cointegração entre mercados de ações tanto de países desenvolvidos como de emergentes demonstram que esses mercados tendem a seguir uma única tendência estocástica comum no longo prazo, mesmo depois de significativas mudanças estruturais. Duas conclusões podem ser tiradas a respeito dessa evidência de cointegração. A primeira seria que a diversificação internacional no longo prazo se torna quase que ineficaz. Então esse tipo de estratégia tem que ser pensado em uma janela de curto prazo para surtir algum resultado significativo. A outra conclusão é que a atividade de arbitragem entre os mercados desses países interligados tem sido eficaz no longo prazo, ou seja, a integração financeira 
favorece a correção de diferenças de preços de ativos idênticos que se encontram em mercados diferentes, reforçando a lei do preço único (KASA, 1992; KIM, KIM, WANG, 2006; GOETZMANN, LI, ROUWENHORST, 2002).

\subsection{Transmissão e contágio nos mercados de ações}

Com uma estrutura de integração financeira cada vez mais robusta entre os mercados de ações de vários países, a transmissão de choques ou inovações de um mercado para outro é algo que tem recebido considerável atenção de pesquisadores, investidores e formuladores de políticas nos últimos 30 anos. $\mathrm{O}$ entendimento dessas interações multilaterais pode trazer, por exemplo, uma grande contribuição no sentido de minimizar potenciais danos causados por uma crise financeira.

Assim, a identificação de padrões de transmissão de choques entre mercados é basal para estratégias de hedging quando o investidor atua além das fronteiras de seu país, servindo também para a elaboração da regulação dos mercados e para a elaboração de orçamentos mais coerentes pelos governantes (GOOIJER, SIVARAJASINGHAM, 2008).

Primeiro é preciso entender quais os principais mecanismos de transmissão e como a dinâmica desses funciona em condições relativamente normais.

Pode-se dizer que a estrutura de interdependência entre os mercados dos países, gerada pela integração financeira, funciona como uma espécie de tubulação por onde os fluxos de capital passarão por meio dos mecanismos de transmissão. Esses fluxos de capital terão sua direção guiada por diferenciais de taxas de juros entre os países e por suas respectivas taxas de inflação. Taxas de juros mais altas conjugadas com uma baixa inflação tendem a mostrar uma maior atratividade para o mercado de títulos de dívida do país, posto que os títulos desse mercado tenham uma rentabilidade baseada nessas taxas de juros. Por outro lado, uma inflação mais alta com taxas de juros mais baixas acaba por depreciar o câmbio, aumentando o poder de compra do investidor estrangeiro, viabilizando a aquisição de ativos estratégicos, aumentando a demanda por ações de empresas desse país, valorizando o índice de seu mercado de ações com efeito inverso no mercado de títulos de dívida (TRACZYK, 2010).

O primeiro meio de transmissão seria o comércio internacional, principalmente o comércio de commodities que tem se expandido consideravelmente nas duas últimas décadas (KEARNEY, LUCEY, 2004). Movimentos de preços de commodities como petróleo impactam os 
mercados, uma vez que dizem respeito a um insumo básico para a grande massa de empresas que compõem os mercados em questão. Assim, um aumento no preço do petróleo, considerado aqui a fonte do choque, pode significar uma queda na lucratividade futura da maioria das empresas, exceto para empresas do setor petrolífero. Como os agregados financeiros representam a expectativa da economia real futura, essa expectativa de queda na lucratividade pode causar uma queda generalizada nos preços das ações de empresas do mundo inteiro. Essa queda nos preços representa, portanto, o valor descontado da possível perda de lucratividade futura segundo as expectativas dos investidores.

Dessa forma, o comércio internacional pode ser a principal fonte de choques que serão transmitidos para os mercados acionários. E esses choques serão transmitidos de acordo com a relação que as empresas possuem com o produto cujo mercado originou o choque. Se a empresa for significativamente dependente do produto analisado, a variabilidade do preço desse produto terá impacto significativo na variabilidade do preço da ação da empresa.

Sob uma visão mais ampla: um choque no mercado de uma commodity comercializada internacionalmente terá efeito na renda disponível dos países e, consequentemente, em suas divisas, o que acaba por afetar sua taxa de câmbio. A consequente variabilidade na taxa de câmbio pode impactar até empresas que não tenham uma relação direta com a commodity do mercado que foi a fonte do choque (TRACZYK, 2010).

Esses choques que são transmitidos entre os mercados também podem ser classificados em choques comuns ou em choques específicos. Os choques comuns são choques de um mercado internacional que acabam afetando todos os mercados ao mesmo tempo, como no exemplo anterior do comércio internacional de commodities. Por outro lado, o choque específico surge em um determinado país e será transmitido para outros países conforme a configuração dos laços comerciais e financeiros que esses outros países possuem com o país originador do choque (WÄLTI, 2009).

Fundamentalmente, o modo como os pesquisadores observam a magnitude e a trajetória desses choques se embasa na análise da variabilidade dos valores dos índices que representam cada um desses mercados, ou seja, os choques são analisados por meio do estudo da evolução das volatilidades dos mercados. Assim, essa variabilidade não tem um padrão constante no tempo devido às respostas aos choques. Adicionalmente, essa volatilidade estará diretamente relacionada ao risco do mercado analisado: quanto mais volátil, mais arriscado. Assim, a 
volatilidade do mercado é um importante parâmetro para qualquer investidor que deseje investir nesse país. Consequentemente, o risco desse mercado, interpretado como um macroativo, também varia no tempo (SANTOS, COELHO, 2010). E esse padrão na evolução das volatilidades pode estar diretamente relacionado com a taxa do fluxo de informação entre os investidores dos mercados dos países (ROSS, 1989).

Quando um mercado recebe um choque exógeno por meio da chegada de uma informação, o primeiro fato que geralmente ocorre é uma dispersão nas expectativas dos investidores em relação ao futuro dos seus investimentos. Nesse primeiro momento, as decisões dos investidores serão tipicamente diferentes das decisões planejadas antes do choque, elevando a volatilidade do mercado. Com a chegada de mais informação para os investidores, acontecerá uma revisão nas expectativas sobre o efeito do choque, com uma consequente revisão nas novas decisões a serem tomadas que estão relacionadas ao efeito do choque, trazendo maior estabilidade para o mercado (SHALEN, 1993).

A partir de dados de alta freqüência, é possível detectar evidências da vida curta desses choques que duram cerca de 30 minutos até uma hora quando se analisa a volatilidade dos valores dos índices que representam os mercados e 45 minutos quando analisado o volume de negociações (SUSMEL, ENGLE, 1994; WONGSWAN, 2006).

Um acontecimento corriqueiro dos mercados que traduz esses choques de vida curta é a grande volatilidade dos preços logo na primeira hora que o mercado reabre. Uma explicação encontrada é que essa alta variabilidade dos preços se deve às novas transações que são resultados do processo de revisão das expectativas que geralmente acontece após a observação do comportamento mais recente dos principais mercados que servem de parâmetro para as decisões dos investidores (KING, WADHWANI, 1990).

Apesar da pouca longevidade desse primeiro impacto, outros estudos conseguiram detectar transmissão de choques entre mercados acionários mesmo com dados de baixa freqüência (KEARNEY, 2000; SCHWERT, 1989).

Esses resultados apontam que a duração e o efeito de uma resposta de um mercado a um choque exógeno pode depender da interpretação do conteúdo informacional intrínseco ao choque pelos agentes dos diferentes mercados. Ou seja, se os investidores interpretarem que o fato que originou o choque pode trazer conseqüências de longo prazo significativas, eles 
podem tomar decisões que causem quebras significativas na estrutura de longo prazo da volatilidade dos mercados (AHLGREN, ANTELL, 2010).

Sobre essas estruturas de volatilidade dos mercados, existem evidências de que essas obedecem mais a padrões regionais que globais (RAHMAN, YUNG, 1994, SUSMEL, ENGLE, 1994). Além disso, as volatilidades observadas podem ser classificadas em "normais", que compõem o intervalo observado em 50\% do tempo, e em "extremas", que são as que ocorrem somente em 5\% do tempo observado (ENGLE, HAKKIO, 1993).

Também existem evidências de uma relação direta entre volatilidade e correlação nos movimentos dos índices representantes dos mercados (LIN, ENGLE, ITO, 1994). Geralmente, um aumento na correlação é precedido de um aumento na volatilidade do mercado, podendo tornar as análises de correlação espúrias. Uma explicação detalhada sobre esse ponto pode ser encontrada em Forbes e Rigobon (2002) e Corsetti et al. (2005).

É válido ressaltar que o aumento de volatilidade e o consequente aumento na correlação acontecem mais frequentemente em momentos de queda generalizada dos índices pelo mundo (bear markets) e não em momentos de alta dos preços (bull markets). Portanto, é possível argumentar que existe uma interação assimétrica entre os mercados dos países em que a direção de queda ou de alta do movimento dos índices dos mercados ditará a intensidade dos comovimentos dos mesmos (KOUTMOS, 1996; LONGIN, SOLNIK, 2001).

A transmissão de choques também depende dos tamanhos dos mercados, ou seja, dos valores de capitalização dos mercados transmissores e receptores. Quanto maior o mercado, maior a chance de esse produzir um impacto significativo em outros mercados. Nesse mesmo raciocínio, quanto maior o mercado, maior a chance desse não responder de forma significativa a choques de outros mercados (TRACZYK, 2010).

Ainda sobre a informação fonte desses choques: Hamao et al. (1990) identificam que os mercados geralmente não respondem de maneira eficiente a informações estrangeiras que venham a impactá-los.

Também é imprescindível entender como a dinâmica da transmissão de choques entre os mercados de ações realmente se processa por todo o mundo. Então aqui será apresentada uma breve explanação de como os principais atores dessa dinâmica geralmente agem, começando pelo estudo do mercado acionário dos Estados Unidos. 
Um dos poucos consensos que existem entre pesquisadores dessa área é a respeito do fato de que os Estados Unidos possuem o mercado de ações mais influente do mundo (EUN, SHIM, 1989; MASIH, MASIH, 2001). Trata-se de um mercado essencialmente transmissor de choques para outros mercados que geralmente respondem aos seus choques em até 24 horas (KNIF, PYNNÖNEN, 1999).

Os mercados de Canadá e México são os mais afetados pelos movimentos do mercado norteamericano por apresentarem uma integração econômica e financeira mais robusta com os Estados Unidos (JOHNSON, SOENEN, 2003; EUN, SHIM, 1989). Logo, os mercados da América Latina também são significativamente afetados (SOYDEMIR, 2000).

Por essa característica, o mercado dos EUA não é usualmente receptor de choques, tendo a maioria dos movimentos dos valores de seu índice explicada por seus próprios valores históricos (BESSLER, YANG, 2003). Assim, o mercado norte-americano é considerado relativamente insulado, não recebendo o efeito contágio, dado que ele é quem transmite esse contágio em tempos de crise financeira (DUNGEY, MARTIN, 2007; AHLGREN, ANTELL, 2010). Entretanto, existem exceções como a crise que ocorreu durante os anos de 1997 e 1998.

Em termos de informação, esse mercado é o maior produtor de informações do mundo. Os anúncios da economia dos Estados Unidos contêm poder significativo na explicação de fatores internacionais que afetam outros países. E investidores por todo o mundo tendem a sobrerreagir a essas informações, causando uma relativa elevação na volatilidade dos outros mercados (MASIH, MASIH, 2001).

Apesar de sua característica transmissora, existem evidências de que o mercado norteamericano é o receptor inicial de choques exógenos que perturbam o equilíbrio de longo prazo existente entre os mercados (MASIH, MASIH, 2001).

Analisando os mercados de ações da Europa, pode-se dizer que existe um alto grau de correlação entre eles, parte disso devido à integração financeira promovida pela União Europeia e pela introdução do euro (BÜTTNER, HAYO, 2011).

Existem evidências de que os mercados europeus parecem não ter um efeito direto sobre os mercados asiáticos. Assim, na arquitetura da transmissão financeira pelo mundo, parece 
existir uma ponte direta que traça a relação entre o mercado norte-americano e os mercados asiáticos (BESSLER, YANG, 2003).

Sendo o europeu mais próximo dos Estados Unidos, o mercado britânico também tem sido considerado um importante receptor inicial de choques exógenos na Europa (MASIH, MASIH, 2001).

O mercado alemão, essencialmente receptor, tem demonstrado uma importante propriedade de acabar com o desequilíbrio de curto prazo. Ao ser um dos primeiros a se recuperar dos choques exógenos, esse mercado costuma se ajustar no curto prazo em direção ao equilíbrio de longo prazo, traçando o movimento que será seguido pelos outros mercados posteriormente. Assim, os movimentos desse mercado são um importante parâmetro para os investidores (MASIH, MASIH, 2001; BESSLER, YANG, 2003).

Os mercados de ações que compõem a região asiática têm sido considerados pela literatura mais receptores que transmissores de choques, mas há fatos que constituem exceções como, por exemplo, a crise asiática (RAHMAN, YUNG, 1994).

Depois da crise asiática, esses mercados têm se mostrado mais integrados entre si, sugerindo a promoção de uma estrutura de interdependência mais regional que global. Entretanto, existem evidências de que esses mercados possuem integração financeira significativa com os países que compõem a OECD (GOOIJER, SIVARAJASINGHAM, 2008).

A influência dos movimentos dos mercados asiáticos é considerada significativa até a região da Europa que geralmente termina de processar os choques que acabam não sendo significativos no mercado norte-americano (BESSLER, YANG, 2003; KNIF, PYNNÖNEN, 1999).

O mercado japonês é significativamente afetado pelo mercado dos EUA, mais especificamente quando se trata da correlação contemporânea entre os movimentos do mercado overnight norte-americano e os movimentos ao longo do dia (horário comercial) do mercado japonês (LIN, ENGLE, ITO, 1994).

$\mathrm{Na}$ Oceania, o mercado australiano possui alta influência. Contudo, se analisado no horizonte de 30 dias, parte significativa de seus movimentos é explicada pelos movimentos do mercado norte-americano e do britânico (BESSLER, YANG, 2003). 
Atenção especial também tem sido dada às características típicas da transmissão de choques em mercados de capitais de países considerados emergentes.

Os mercados de países emergentes têm aumentado sua importância no mundo após passarem por algumas reformas e após o crescimento da liquidez internacional na última década que viabilizou maior fluxo de investimentos em mercados emergentes (SOYDEMIR, 2000; AGGARWAL, KIAW, 2005; YU, FUNG, TAM, 2010).

Esses mercados também têm sido considerados menos eficientes que os mercados dos países desenvolvidos, usualmente com uma maior duração da resposta a choques exógenos. Entretanto, esses mercados tendem a responder de maneira mais ágil a choques gerados internamente, demonstrando, portanto, a importância dos fatores nacionais. Assim, esses mercados são tipicamente mais voláteis, gerando maior risco para o investido estrangeiro (SOYDEMIR, 2000; MASIH, MASIH, 2001).

Também é observado um impacto significativo de notícias relativas a fundamentos macroeconômicos dos países desenvolvidos nesses mercados, impactando tanto a volatilidade desses mercados como o volume de negociação dos mesmos (WONGSWAN, 2006).

No estudo da transmissão de choques entre os mercados, os momentos de crises mundiais têm mostrado um padrão especial nessa transmissão, esse padrão é amplamente conhecido como efeito contágio ou simplesmente contágio.

$\mathrm{Na}$ literatura ainda não há consenso sobre o que é e o que não é contágio. Esse fenômeno pode corresponder ao aumento significativo da correlação entre os movimentos dos mercados em curto espaço de tempo. Por outro lado, os movimentos das correlações podem apenas espelhar a estrutura de interdependência entre os mercados e não um efeito específico que aconteceria em tempos de crise (FORBES, RIGOBON, 2002).

Forbes e Rigobon (2002) propõem que um aumento significativo na correlação entre índices dos mercados dos Estados Unidos e do Canadá, por exemplo, apenas reflete o alto grau de integração financeira entre esses dois países. Enquanto a identificação de um impacto significativo no mercado brasileiro referente a um choque proveniente do mercado russo seria uma forte evidência de contágio, posto que esses países não se encontrem tão próximos e não mantêm relações comerciais tão significativas. Assim, pode ser considerado que o contágio entre os mercados apenas reforça os mecanismos de transmissão (COLLINS, BIEKPE, 2003). 
Contágio também pode ser definido como a mudança nos mecanismos de propagação de choques entre países em períodos de crise. E uma definição mais generalista e ampla descreve contágio como a transmissão de choques entre países, colocando uma faixa cinzenta entre o que é uma transmissão entre mercados em condições normais e o que é o próprio contágio. Nessa perspectiva, qualquer transmissão de choques de um mercado para outro pode ser considerada contágio (AHLGREN, ANTELL, 2010).

Também existe uma investigação se o contágio nos mercados está baseado em fundamentos macroeconômicos ou se está mais para um efeito comportamental dos investidores, mais conhecido como contágio psicológico (DORNBUSCH, PARK, CLAESSENS, 2000). Na segunda hipótese, ao perceberem a iminência de uma crise, os investidores começam a se comportar da mesma forma: liquidando investimentos de maior risco e rapidamente aplicando nos ativos mais seguros disponíveis, mesmo sem uma análise mais profunda da crise e suas possíveis conseqüências, demonstrando relativa irracionalidade. Existem evidências que suportam as duas hipóteses. Portanto, o contágio pode ser produto tanto de mudanças significativas nos fundamentos macroeconômicos quanto do comportamento de rebanho dos investidores (HARDOUVELIS, 1998; CONNOLY, WANG, 2003).

Dado que parte dos movimentos dos mercados são apenas ruídos decorrentes da ineficiência dos mercados, pode ser conjecturado que parte das reações aos choques diz respeito a um processamento ineficiente de ruídos que, na verdade, não deveriam gerar nenhum tipo de reação (KING, WADHWANI, 1990).

Parte desse erro e da transmissão do mesmo pelos mercados pode ser explicada pela assimetria de informação entre os agentes que compõem os mercados. Por falta de informação, alguns agentes poderão pensar que o efeito será maior do que realmente será, tomando decisões drásticas, gerando maior volatilidade para os mercados (COLLINS, BIEKPE, 2003).

Esse contágio em tempos de crise também tem causado quebras estruturais simultâneas nas tendências de movimento dos mercados (AHLGREN, ANTELL, 2010).

Pressupondo que parte da correlação entre os desempenhos dos mercados pode ser explicada por fatores internacionais (correlação condicional) e outra parte seria explicada por outros fatores (correlação incondicional), a análise do fenômeno contágio também mostra que, em 
momentos de crise, a correlação condicional dos mercados tem um salto significativo em relação à correlação incondicional. Isso mostra que o contágio tende a aumentar o peso dado pelos investidores às informações sobre os outros mercados (KENOURGIOS, SAMITAS, PALTALIDIS, 2011; CAPPIELO, ENGLE, SHEPPARD, 2006).

\subsection{Decoupling}

Depois da crise asiática, alguns governos dos países da Ásia adotaram importantes medidas que contribuíram para um crescimento significativo das principais economias desse continente, tendo como principais expoentes China e Índia. O contraste de desempenhos entre esses países e os países desenvolvidos tem sido o foco de diversos estudos que buscam investigar as causas e implicações desse fenômeno conhecido como decoupling (KIM, LEE, 2008; JAYARAM, PATNAIK, SHAH, 2009; KIM, LEE, PARK, 2011).

Com a crise financeira de 2008, estudos sobre a hipótese de decoupling nos mercados acionários tornaram-se mais freqüentes, uma vez que os mercados dos países emergentes demoraram mais que os mercados dos países desenvolvidos para sentir os efeitos adversos da crise. Nesses mercados emergentes, as quedas significativas nos indicadores só foram observadas a partir da quebra do banco Lehman Brothers (DOOLEY, HUTCHINSON, 2009).

Sendo um tema ainda recente, o conceito de decoupling ou descolamento, como é dito em Sousa et al. (2011), ainda não tem uma definição precisa que seja um consenso entre os pesquisadores. A existência de várias versões do que seria exatamente decoupling só demonstra que ainda não há pleno entendimento sobre o fenômeno.

Dessa forma, ao invés de apresentar uma definição sucinta e imprecisa, serão discutidos os principais aspectos sobre o fenômeno fornecidos pela literatura com o intuito de delinear as fronteiras que definem o conceito, ou seja, até onde é ou não é decoupling.

Como ponto de partida, pode-se argumentar que o fenômeno do decoupling compreende uma diferença significativa entre os desempenhos econômicos de países emergentes e de países desenvolvidos. Assim, em linha com esse ponto de vista, Willet et. al (2011) propõem que os ciclos de negócios dos países emergentes são mais independentes dos ciclos de negócios dos países desenvolvidos quando existe uma relação de decoupling. Esses autores também apresentam que o principal parâmetro para a identificação de decoupling é o desempenho da economia dos Estados Unidos. 
A definição anterior traz implícita a ideia de sincronia. Mais precisamente, a definição sinaliza para uma falta de sincronia significativa entre as economias emergentes e as desenvolvidas.

A primeira discussão que surge é se essa falta de sincronia se refere a trajetórias significativamente diferentes ou a trajetórias significativamente opostas (FIDRMUC, KORHONEN, 2010; SOUSA, YOSHINO, BIANCONI, 2011).

Em termos matemáticos, a primeira configuração sugere que esse fenômeno aconteceria quando o coeficiente de correlação linear entre os indicadores de desempenho dos dois grupos de países é igual a 0 e, na segunda configuração, seria igual a -1.

Essas duas primeiras ideias contemplam um conceito mais geral, ou seja, não importa qual grupo de países está melhor desde que exista uma diferença significativa entre os indicadores deles.

Adicionalmente, existe a visão de que o decoupling compreende uma diferença significativa entre os desempenhos de emergentes e desenvolvidos, mas essa diferença é caracterizada pela superioridade da performance dos países emergentes em relação aos desenvolvidos, ou seja, essa versão diz que os emergentes observarão sistematicamente taxas mais altas de crescimento econômico que os desenvolvidos (MAJID, KASSIM, 2009).

Essa última ideia deixa nítido o conceito de tendência e não somente a falta de sincronia por si só.

Para continuar a discussão e viabilizar a análise estatística que será realizada, são desenvolvidas aqui as seguintes definições operacionais:

1. Decoupling de independência: correlação entre indicadores de países emergentes e desenvolvidos é igual a 0 ;

2. Decoupling de oposição: correlação entre indicadores de países emergentes e desenvolvidos é igual a -1; e

3. Decoupling pró-emergentes: performances dos países emergentes sempre melhores que a performance dos desenvolvidos. 
Em geral, as evidências a respeito têm demonstrado que nenhuma forma de decoupling foi encontrada plenamente e o efeito observado não dura por muito tempo. Portanto, existem descolamentos parciais e não absolutos como nas categorias apresentadas acima (ROSSI, 2008; PULA, PELTONEN, 2009).

Diante desse cenário, em uma janela de tempo relativamente grande, a instabilidade observada na magnitude do decoupling identificado pode apontar para a possibilidade de que esse fenômeno apenas reflete o padrão cíclico de um fenômeno maior que abrange o momento de decoupling e o de recoupling, ou seja, quando os desempenhos convergem. Assim, após uma situação de decoupling, os desempenhos de emergentes e de desenvolvidos tendem a se igualar (WILLET, LIANG, ZHANG, 2011).

Com base nisso, é possível afirmar que o decoupling não corresponde a um fenômeno de duração permanente e, sim, temporário. Além disso, como já abordado na subseção 2.2, os países possuem indicadores cointegrados tanto em termos de economia real como em termos financeiros, ou seja, seguem a mesma tendência no longo prazo. Portanto, é plausível afirmar que esse descolamento não corresponde a um fenômeno de longo prazo (ROSSI,2008). Entretanto, na literatura sobre o tema ainda não existe um estudo específico que estude a duração do fenômeno. Assim, não se pode afirmar que corresponde a um fenômeno de curto ou de médio prazo. Pressupondo que é um fenômeno que surgiu na última década (janela de tempo dos estudos sobre o tema), pode-se argumentar que os trabalhos que encontram evidências de decoupling sugerem um fenômeno de médio prazo. E os trabalhos que não encontram evidências significativas geralmente sugerem que se trata apenas de um fenômeno de curto prazo que tem ocorrido mesmo antes da última década.

Colocada a possibilidade de que o decoupling pode não durar por muito tempo, esse fenômeno também pode ser interpretado como uma ruptura temporária na tendência de longo prazo, isto é, o decoupling corresponde a uma quebra na estrutura de interdependência entre os países que posteriormente é restabelecida (WÄLTI, 2010).

Seguindo esse raciocínio, o conceito de decoupling pode ser refinado com a ideia de que as economias de alguns países emergentes podem demorar mais que as economias dos países desenvolvidos para responder a um choque. Mas, uma vez que os efeitos desse choque tenham sido sentidos nos países emergentes, as taxas de crescimento dos dois grupos de países tendem a convergir em um movimento de queda. E a duração do período de resistência 
também dependerá da magnitude do choque, ou seja, quanto maior o choque, mais rapidamente ele será transmitido. Assim, o conceito não abrange apenas ciclos ou tendências, mas também a sensibilidade da economia do país emergente a choques externos. Dessa forma, quanto menor a sensibilidade a choques externos, mais frequentemente a economia terá um desempenho melhor em relação à economia de um país que reage mais rápido a esses choques (LEVY-YEYATI, 2009, WILLET, LIANG, ZHANG, 2011).

Com o que foi exposto até aqui, é importante ressaltar que, independente da duração, o que caracteriza o fenômeno é o diferencial significativo de desempenhos entre os países emergentes e os desenvolvidos que tem ocorrido frequentemente e de forma sistemática na última década.

As políticas governamentais contra-cíclicas dos países emergentes estão entre os fatores que explicam o decoupling e, de certa forma, essas políticas objetivam isolar a economia desses países de choques advindos dos mercados internacionais (WÄLTI, 2009).

Uma dessas políticas seria o aumento significativo das reservas internacionais de câmbio. Com essas reservas, é possível aos governos de economias emergentes a intervenção no câmbio a favor de seus países em prol da blindagem da economia contra choques adversos observados nos mercados mundiais. Assim, fica viável manter uma taxa de câmbio competitiva que mantenha o ritmo das exportações dos países emergentes (CHINN, FRANKEL, 2008; QUAH, 2010).

Contudo, essa proteção por meio de reservas internacionais é possível até certo ponto. Como já apresentado, dependendo da magnitude do choque recebido, esse mecanismo pode não ser suficiente para inibir efeitos adversos na economia.

Como já analisado na subseção anterior, a sensibilidade a esses choques também depende do tamanho da economia do país.

Grande parte desses estoques de reservas internacionais se deve ao aumento dos níveis de investimento direto estrangeiro em países emergentes que também aumentou o nível de liquidez nos mercados internacionais, como visto na subseção 2.2.

Outro fator é a redução na dívida líquida externa dos países emergentes, principalmente na Ásia. E parte dessa redução é explicada por uma série de políticas restritivas. No grupo das 
políticas restritivas implementadas estão: a geração de superávit fiscal, balança comercial com saldo positivo e o monitoramento das dívidas em moedas estrangeiras das empresas desses países (DOOLEY, HUTCHINSON, 2009).

Focando os mercados de ações, outro possível fator para explicar o diferencial de desempenho entre emergentes e desenvolvidos pode ser o grau de abertura financeira observado nesses mercados. Em comparação com os mercados de países desenvolvidos, os mercados de países emergentes possuem, em média, menor grau de abertura financeira. Assim, esses mercados emergentes estarão menos integrados, observando uma menor magnitude no grau de comovimentos com os mercados de países desenvolvidos (MORALES, GASSIE, 2011; KORAJCZYK, 1995).

Considerados os principais exemplos de situações de decoupling, os países emergentes da Ásia também conseguiram maior destaque na produção de bens manufaturados por meio da imitação ou adaptação de tecnologias advindas dos países desenvolvidos ou pela criação de tecnologia própria. Na produção, em países como China e Índia, o diferencial da mão-de-obra barata fez com que os bens produzidos gerassem um aumento geral no valor adicionado mesmo com baixos preços nos mercados, aumentando os níveis de crescimento econômico. $\mathrm{E}$ além dos investimentos estrangeiros, esses países beneficiaram-se de seus altos níveis de poupança que garantem níveis menores de investimento público para manter o ritmo do crescimento econômico (HIRAKAWA, AUNG, 2011; KIM, LEE, PARK, 2011).

Com esse crescimento, a nova população urbana vem incrementando o consumo nesses países, fortalecendo seus mercados domésticos. Com um mercado doméstico mais forte, esses países também reduziram sua dependência em relação ao consumo de seus bens por outros países. Adicionalmente, a demanda incremental desses países gerou um aumento na importação de commodities que, além de expandir o mercado internacional de commodities, alavancou a produção de outros países emergentes que são essencialmente produtores e exportadores de commodities como Rússia e Brasil (WÄLTI, 2009; KIM, LEE, PARK, 2011).

Outro fator que ajuda a explicar o decoupling seria a intensificação do comércio intrarregional na Ásia. Com o estreitamento dos laços comerciais entre os países da região, os movimentos dos indicadores de suas economias tendem a ser mais diferentes dos movimentos dos indicadores das economias de países desenvolvidos (KOSE, OTROK, PRASAD, 2012). 
Mais precisamente: com a intensificação do comércio intrarregional, os países da região tendem a ficar mais dependentes entre si e mais independentes dos países externos à região, gerando um quadro de decoupling (WILLET, LIANG, ZHANG, 2011).

Dentre as implicações desse fenômeno, é observável que o crescimento econômico de países emergentes tem sido significativamente explicado pelos fatores regionais. Os fatores globais ainda são determinantes significativos do crescimento econômico, mas a sua importância agora é dividida com movimentos dos grupos ou regiões que os países emergentes são integrantes, potencializando as diferenças entre emergentes e desenvolvidos em termos de crescimento econômico (KOSE, OTROK, PRASAD, 2012).

Também é observado que esses países compõem uma integração vertical de suas cadeias de produção. Para melhor entendimento, é necessário visualizar esse grupo de países emergentes asiáticos como uma grande fábrica em que cada país pode ser considerado um departamento dessa fábrica. Assim, bens primários são produzidos em um "departamento-país” e são exportados para outro "departamento-país" que processará esses bens e terá como output um bem intermediário que também será exportado. Continuará assim até chegar ao bem final que também pode ser exportado para algum país fora da região. Portanto, também existe uma rede de comércio que envolve países externos à região e enfraquece a independência dos países emergentes em relação a choques provenientes dos mercados externos à região $(\mathrm{KO}$, PASCHA, 2011; KIM, LEE, PARK, 2011).

Quando a relação de decoupling diz respeito somente aos países emergentes asiáticos, autores como Krugman (1993), Kose e Yi (2002), Imbs (2004 e 2006) e Akin e Kose (2008) relacionam o fenômeno ao fato de que esses países possuem composições setoriais semelhantes e, ao mesmo tempo, diferentes das composições dos países desenvolvidos. Portanto, se os choques são específicos por setor, existirá uma diferença entre as reações dos países emergentes asiáticos e dos países desenvolvidos. Além de setores relativamente iguais, os países emergentes asiáticos estão integrados economicamente pelo comércio intrassetor, fato que também justifica as covariação das flutuações das economias desses países.

O surgimento de decoupling nos mercados acionários também pode se referir à percepção dos investidores, uma vez que suas decisões são tomadas com base nos desempenhos regionais e nos números da economia real e, dessa maneira, esse descolamento é resultado de um modelo 
mental dos investidores que se constitui em decisões de curto e médio prazo (JAYARAM, PATNAIK, SHAH, 2009; WILLET, LIANG, ZHANG, 2011).

O crescimento da influência dos países emergentes no cenário mundial pode ser interpretado como um efeito agregado do decoupling (AKIN, KOSE, 2008; KIM, LEE, PARK, 2011).

Antes, as relações econômicas entre países desenvolvidos e emergentes construíam uma determinada configuração onde os choques eram unidirecionais, ou seja, o único movimento observado era o impacto das economias desenvolvidas nas economias emergentes. Recentemente, tem sido percebido um padrão bidirecional nas transmissões de choques entre os dois grupos de países. Dessa forma, economias desenvolvidas também têm sido significativamente impactadas por choques provenientes dos países emergentes (KIM, LEE, PARK, 2011).

Vale ressaltar que a maioria das pesquisas sobre decoupling tem focado na evolução das taxas de crescimento, não levando em consideração outros dados que contemplem outras dimensões das economias analisadas como, por exemplo, a verificação da existência de decoupling nos movimentos dos mercados de capitais.

Quando se utilizam dados financeiros, geralmente é encontrado que, mesmo em momentos de elevada turbulência nos mercados de ações como na crise financeira de 2008, certo grau de decoupling entre países desenvolvidos e emergentes pode ser observado.

Nessa crise, cujos primeiros sinais surgiram por volta de fevereiro de 2007 , foi constatado que até meados de maio de 2008, enquanto os países desenvolvidos observavam quedas significativas nos valores dos ativos de seus mercados acionários, a maioria das economias de países emergentes estava de certa forma isolada, pois os ativos de seus mercados acionários não sofreram nenhuma desvalorização significativa, caracterizando o decoupling e, inclusive, foi observada uma apreciação do câmbio da maioria desses países. Durante esse período, os bancos dos países emergentes estavam aparentemente muito pouco expostos aos títulos contaminados referentes à origem da crise, principalmente devido à rígida regulação dos sistemas bancários existente nesses países (DOOLEY, HUTCHINSON, 2009).

Nesse caso, pode ser argumentado que, durante o período relatado, aconteceu um caso genuíno de decoupling pró-emergentes. 
Entretanto, a partir do meio do mês de maio de 2008 até o dia 15 de setembro, dia em que foi decretada a falência do banco Lehman Brothers, houve um período de revisão de expectativas pelos investidores de todo o mundo e, assim, foi fortalecida a hipótese de que os emergentes seriam igualmente afetados pela crise que se desenrolava. Desse ponto em diante, teve início o movimento de recoupling dos mercados, com quedas nos índices das bolsas de valores dos países emergentes. Por fim, a partir do meio do mês de setembro até o fím de 2008, quando a base de crédito do mundo foi significativamente reduzida, foram observadas quedas agudas nos valores dos ativos dos mercados acionários dos países emergentes, sendo detectada, inclusive, uma desvalorização com uma magnitude ainda maior que a observada nos países desenvolvidos. Mas, em 2009, os mercados de Índia e China já tinham se recuperado consideravelmente enquanto os mercados dos países desenvolvidos ainda sofriam com a crise (DOOLEY, HUTCHINSON, 2009).

Dependendo do ponto de vista, é possível afirmar que ainda houve decoupling nesse terceiro estágio da crise, uma vez que a maior desvalorização nos países emergentes em comparação com os desenvolvidos não deixa de apresentar um contraste significativo entre esses dois grupos, mesmo que os movimentos dos indicadores aconteçam segundo a mesma direção. Evidentemente que, se visto sob essa perspectiva, o decoupling identificado obteve uma configuração muito diferente do caso que ocorreu no primeiro estágio da crise.

Assim, por meio do estudo dessa crise, é possível constatar que o fenômeno de decoupling possui uma natureza cíclica e esse ciclo termina quando uma crise atinge criticamente o sistema financeiro mundial, impactando todos os países e gerando um movimento de recoupling, movimento de convergência nos desempenhos, que depois pode ser revertido para uma situação de decoupling novamente.

Essa natureza cíclica pode ser interpretada apenas como parte dos ciclos econômicos que sempre aconteceram nos países (FLOOD, ROSE, 2010; WÄLTI, 2009 e 2010).

Entre os argumentos que defendem a não existência de decoupling, está a tese de que o progresso dos países emergentes se deve à participação crescente do capital estrangeiro nesses países, principalmente na forma de investimento direto externo. E esse investimento, na maioria das vezes, advém de investidores dos países desenvolvidos. Assim, quando os países desenvolvidos sofrem um revés em sua economia, esses investidores, prevendo a propagação da crise, fazem com que parte relevante do investimento nos países emergentes seja reduzida 
e essa redução, portanto, tem um efeito negativo no crescimento das economias dos países emergentes, descaracterizando o decoupling (LEE, PARK, 2008).

Adicionalmente, os países que melhor representam os emergentes nas situações de decoupling geralmente são países da Ásia. E países como Índia e China, por exemplo, possuem economias significativamente internacionalizadas, ou seja, o valor de suas exportações constitui proporção relevante de seu PIB, tendo como importantes parceiros comerciais Estados Unidos, Japão e países desenvolvidos da Europa. Assim, essa internacionalização de suas economias aumenta sua exposição às variações do mercado internacional, fazendo com que certas políticas consideradas contra-cíclicas não sejam plenamente eficazes (KIM, LEE, PARK, 2011).

Pesquisas com outros tipos de indicadores além de taxas de crescimento também revelam resultados que estão em linha com a hipótese de recoupling. Felices e Wieladek (2012) encontraram que fatores comuns globais explicam cerca de $60 \%$ da evolução dos indicadores de vulnerabilidade econômica dos países emergentes. Exemplos desses indicadores seriam: o quociente entre reservas internacionais e dívidas externa de curto prazo ou a dívida externa total em termos de exportações, entre outros.

Dessa forma, é possível afirmar que a dívida externa dos países emergentes possui uma correspondência maior com os movimentos dos mercados internacionais que com os efeitos de políticas internas. Assim, esse achado também reforça a visão de que o isolamento de efeitos de choques adversos advindos do exterior pode não ser identificado dependendo do indicador analisado.

Quando se analisa o desempenho do grupo dos países emergentes, também é nítida a heterogeneidade dentro desse grupo. Países emergentes como Brasil e México possuem forte vínculo comercial com os Estados Unidos, gerando um alto grau de comovimentos entre os mercados desse e daqueles, enfraquecendo a hipótese de decoupling significativo para esses países. Geralmente todos os países emergentes são significativamente impactados por movimentos dos mercados internacionais. Exemplo disso é a Rússia que tem a evolução de sua economia diretamente ligada à evolução do mercado internacional de gás e petróleo, principais produtos produzidos nesse país (ALOUI, AISSA, NGUYEN, 2011).

Assim, também existe a tese de que a influência dos países desenvolvidos sobre as economias emergentes ainda é muito grande, fazendo com que sejam raros os momentos em que haja 
uma diferença significativa de desempenho entre esse país e os países emergentes (WÄLTI, 2009 e 2010).

Nos quadros de 1 a 4 consta um resumo de algumas das principais contribuições dos trabalhos que estão entre os mais importantes sobre o tema e que foram citados nesse capítulo.

\begin{tabular}{|l|l|}
\multicolumn{2}{|c|}{ Quadro 1- Alguns trabalhos e suas contribuições para o estudo do tema BRICS } \\
\hline \multicolumn{2}{|l|}{ BRICS } \\
\hline Trabalhos & Contribuição e/ou Achados \\
\hline Armijo (2007) & $\begin{array}{l}\text { Análise do grupo BRIC como uma categoria particular de países, levantando fatores que } \\
\text { fazem com que esses países formem um grupo diferenciado. }\end{array}$ \\
\hline Santos (2010) & $\begin{array}{l}\text { Documentou a intensificação do comércio entre os BRICS na última década. } \\
\text { Levanta a hipótese de que a China é a principal fonte do dinamismo econômico do } \\
\text { grupo. }\end{array}$ \\
\hline $\begin{array}{l}\text { Holtbrügge } \\
\text { Kreppel (2012) }\end{array}$ & $\begin{array}{l}\text { Análise dos principais determinantes do fluxo de investimentos diretos estrangeiros para } \\
\text { o grupo BRIC. }\end{array}$ \\
\hline $\begin{array}{l}\text { Bekaert et al. (2003) } \\
\text { Estima os anos de liberalizações financeiras de fato das economias emergentes, incluindo } \\
\text { os BRICS. }\end{array}$ \\
\hline $\begin{array}{l}\text { Estrin e Prevezer } \\
(2010)\end{array}$ & \begin{tabular}{l} 
Avaliação das dificuldades de entrada de novas firmas nos países do BRIC. \\
\hline Chittedi (2009)
\end{tabular} \\
\hline
\end{tabular}
Elaborado pelo autor.

Quadro 2 - Alguns trabalhos e suas contribuições para o estudo do tema integração financeira

\begin{tabular}{|l|l|}
\hline \multicolumn{2}{|c|}{ Integração financeira } \\
\hline Trabalhos & Contribuição e/ou Achados \\
\hline $\begin{array}{l}\text { Johnson e Soenen (2003), Aggarwal e Kiaw (2005), } \\
\text { Frankel e Rose (1998) e Hamao et. al (1990) }\end{array}$ & $\begin{array}{l}\text { Relação significativa entre comércio e integração } \\
\text { financeira entre os países. }\end{array}$ \\
\hline Phylaktis e Ravazzolo (2002) & $\begin{array}{l}\text { Integração entre os mercados emergentes e os } \\
\text { desenvolvidos está aumentando e é significativa. }\end{array}$ \\
\hline Bekaert et. al (2004) & $\begin{array}{l}\text { Relação significativa entre integração financeira e } \\
\text { crescimento econômico. }\end{array}$ \\
\hline Bekaert et. al (2002) & $\begin{array}{l}\text { Relação entre integração financeira e evolução do } \\
\text { câmbio. }\end{array}$ \\
\hline
\end{tabular}

Elaborado pelo autor.

Quadro 3 - Alguns trabalhos e suas contribuições para o estudo do tema transmissão financeira e contágio

\begin{tabular}{|l|l|}
\hline \multicolumn{2}{|c|}{ Transmissão financeira e contágio } \\
\hline Trabalhos & Contribuição e/ou Achados \\
\hline Shalen (1993) & $\begin{array}{l}\text { Relação entre a transmissão de choques entre os mercados e as crenças dos } \\
\text { investidores. }\end{array}$ \\
\hline $\begin{array}{l}\text { Lin et. al (1994) e Forbes e } \\
\text { Rigobon (2002) }\end{array}$ & $\begin{array}{l}\text { Análise da relação entre volatilidade e correlação entre os desempenhos dos } \\
\text { mercados acionários. }\end{array}$ \\
\hline $\begin{array}{l}\text { Eun e Shim (1998) e Masih } \\
\text { e Masih (2001) }\end{array}$ & Mercado acionário dos EUA é o mais influente. \\
\hline $\begin{array}{l}\text { Hardouvelis (1988) e e } \\
\text { Connoly e Wang (2003) }\end{array}$ & $\begin{array}{l}\text { Investigação da origem de bolhas especulativas e sua relação com fundamentos } \\
\text { macroeconômicos e comportamento de rebanho dos investidores. }\end{array}$ \\
\hline
\end{tabular}


Quadro 4 - Alguns trabalhos e suas contribuições para o estudo do tema decoupling

\begin{tabular}{|l|l|}
\hline \multicolumn{2}{|c|}{ Decoupling } \\
\hline Trabalhos & Contribuição e/ou Achados \\
\hline Kim et al. (2011) & $\begin{array}{l}\text { Evidências de choques bidirecionais entre as economias dos países emergentes e } \\
\text { desenvolvidos. }\end{array}$ \\
\hline $\begin{array}{l}\text { Dooley ey } \\
\text { Hutchinson (2009) }\end{array}$ & Possível decoupling nos mercados acionários, incluindo os países do BRIC. \\
\hline Willet et. al (2011) & Conceito de decoupling. Possível padrão cíclico do fenômeno decoupling. \\
\hline Wälti (2009) & Políticas contra-cíclicas dos países emergentes como fatores do decoupling. \\
\hline Wälti (2010) & $\begin{array}{l}\text { Decoupling seria apenas uma quebra temporária na estrutura de interdependência das } \\
\text { economias, fato que sempre aconteceu. }\end{array}$ \\
\hline Kose et. al (2012) & $\begin{array}{l}\text { Comércio intrarregional da Ásia relacionado ao desempenho diferenciado dos países } \\
\text { asiáticos. Fator grupo tem aumentado seu poder de explicação dos desempenhos dos } \\
\text { países. }\end{array}$ \\
\hline
\end{tabular}

Elaborado pelo autor. 


\section{METODOLOGIA}

\subsection{Abordagem e método}

A estratégia de pesquisa é composta de um estudo empírico-analítico em que um modelo com definições operacionais fundamentadas nas teorias já apresentadas é desenvolvido, delineando uma conjectura cuja validade é testada por meio da técnica de análise de regressão.

A escolha dessa estratégia encontra base nos seguintes motivos:

1. Origem e natureza do problema de pesquisa; e

2. Tradição de uma abordagem positivista nos trabalhos de mesmo tema.

Os estudos apresentados na fundamentação teórica, que serviram de base para o desenvolvimento do problema de pesquisa, não abordam esse problema em sua plenitude. $\mathrm{Na}$ verdade, cada estudo abrange um aspecto do problema, fato que, mesmo com a análise conjunta dos trabalhos, impossibilita a elaboração de uma resposta plausível e confiável para o problema. Disso surge a necessidade de um estudo que utilize os dados desses trabalhos anteriores, mas que se desenvolva segundo uma estrutura de análise que aborde diretamente todos os aspectos do problema em questão.

Posto que os dados de entrada desses estudos são quantitativos, o caminho lógico a seguir foi empregar uma metodologia que tenha esses dados quantitativos como input. Assim, seguiu-se a estrutura da maioria dos trabalhos de mesmo tema que empregam a análise de regressão a partir de dados quantitativos sobre os mercados acionários objetos de estudo.

Evidentemente, uma possível significância dos parâmetros das variáveis independentes analisadas não implica necessariamente uma relação de causalidade, mas esse tipo de evidência pode servir como suporte para o direcionamento de outros estudos que abordem essa possível causalidade de outra maneira, validando, portanto, o uso da análise de regressão.

\subsection{Amostragem}

Considerando que os fenômenos observados, motivadores do presente estudo, surgiram na última década, não existe a necessidade de estender a janela de tempo em que a análise de regressão será realizada para antes do início dessa mesma década. Com isso, a janela de 
tempo definida para a coleta de dados inicia-se no primeiro dia útil do ano de 2001 e segue até 31 de outubro de 2012.

Os dados utilizados são:

1. Os valores de fechamento mensais dos índices em dólar que representam as bolsas dos respectivos países do BRICS e dos Estados Unidos; e

2. Os valores de capitalização de mercado em dólar de cada uma das bolsas em 31 de outubro de 2012.

Uma vez que os mercados acionários dos BRICS e dos EUA são os objetos de estudo, os índices que representam os valores das ações das principais empresas que constituem esses mercados (e suas respectivas evoluções no tempo) mostram-se adequados como proxies dos desempenhos desses mercados (BRACKER, DOCKING, KOCH, 1999; SECURATO, OLIVEIRA, 1998). A relação dos índices a serem coletados segue abaixo (Quadro 5):

Quadro 5 - Países e respectivos índices dos mercados de ações colet
\begin{tabular}{|c|c|}
\hline País & Índice de mercado de ações \\
\hline África do Sul & FTSE/JSE All Africa Share Index (JALSH) \\
\hline Brasil & IBrX \\
\hline Brasil & Ibovespa \\
\hline China & Shangai Se Composite Index (SHCOMP) \\
\hline Estados Unidos & S\&P 500 (SPX) \\
\hline Índia & Bombay Stock Exchange Index (Sensex30) \\
\hline Rússia & Russian RTS Index (RTSI1) \\
\hline Mundo & MSCI World Index \\
\hline
\end{tabular}

Fonte: Bloomberg®. Elaborado pelo autor.

A escolha por dados mensais fundamentou-se em trabalhos como o de Kearney (2000) em que os movimentos de transmissão financeira entre mercados acionários são captados mesmo com dados de baixa freqüência (de periodicidade mensal).

Com base nos achados de Büttner e Hayo (2011), que concluem que os determinantes nominais explicam melhor a integração financeira em comparação com determinantes em termos reais, os valores dos índices não foram deflacionados.

A base de dados utilizada para a coleta dos índices foi a da empresa Bloomberg®. Os valores de capitalização de mercado foram coletados no site www.world-exchanges.org e o programa para organização dos dados foi o Microsoft Excel $2007^{\circledR}$. E o programa para a realização dos testes foi o Eviews $7^{\circledR}$. 


\subsection{Modelo}

Em primeiro lugar, é necessário medir os desempenhos dos mercados. Tendo os valores em dólar dos índices como séries de preços de cada um dos mercados envolvidos, os desempenhos são medidos a partir dos retornos desses preços. Adicionalmente, os retornos estarão na forma de log-retornos ou retorno composto continuamente, cujas propriedades estatísticas são mais tratáveis (TSAY, 2005). O log-retorno é obtido a partir do logaritmo natural dos valores dos índices:

$$
r_{t}=\ln \left(\frac{P_{t}}{P_{t-1}}\right)=\ln \left(P_{t}\right)-\ln \left(P_{t-1}\right)
$$

Onde $P_{t}$ e $P_{t-1}$ são os valores convertidos do índice analisado nos instantes $t$ e $t-1$, respectivamente. A partir daqui, será subentendido o uso de log-retorno quando se mencionar a palavra retorno.

Os próximos tópicos desta subseção possuem o objetivo de inicialmente descrever toda a conjectura que foi desenvolvida e que embasa a expressão matemática do modelo que foi testado. E para a descrição dessa conjectura são revisitados objetivamente os conceitos já apresentados na fundamentação teórica e que ajudam a sustentar os pressupostos que embasam toda a conjectura e modelo.

\subsubsection{Pressupostos e modelagem da integração financeira}

Como ponto de partida, a Figura 1 é apresentada novamente e, como exposto na subseção 2.1, essa figura busca resumir os principais fluxos comerciais entre os países do BRICS:

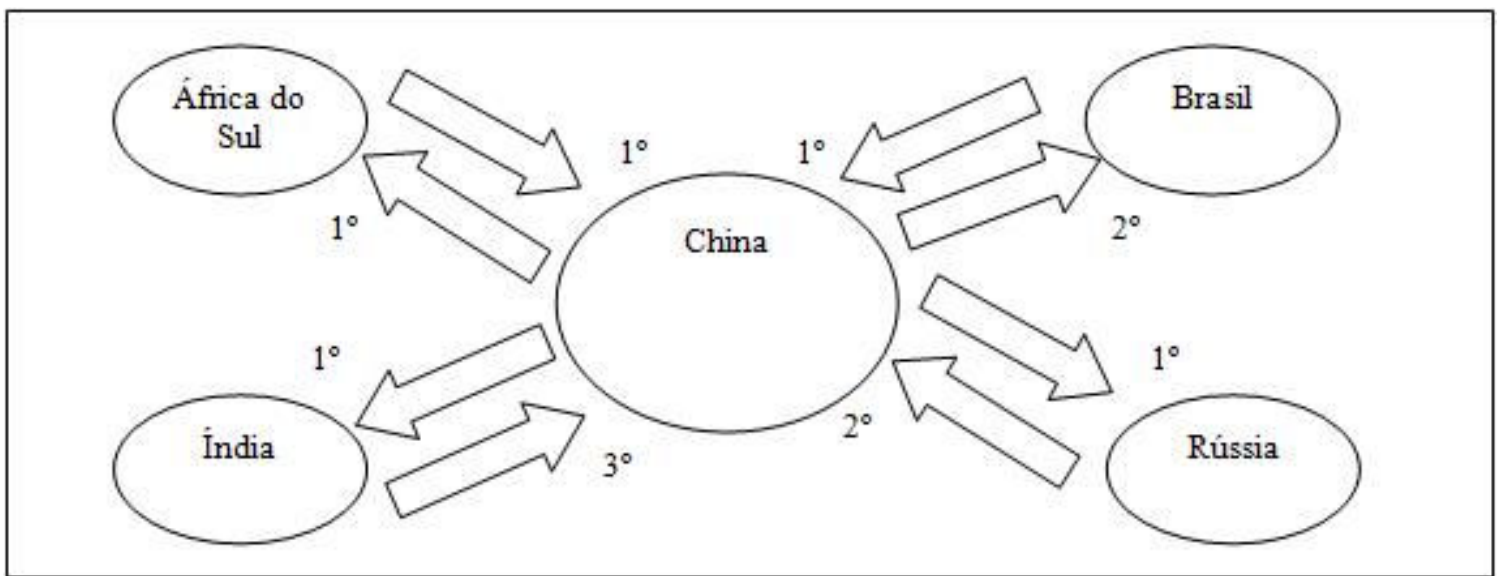

Figura 1 - Importância da China para o comércio internacional dos outros países do BRICS em 2011 FONTE: CIA, 2012. Elaborada pelo autor. 
Como Santos (2010) demonstra: antes dos anos 2000, o fluxo comercial entre os países do BRICS era menor que o observado atualmente, em termos relativos e absolutos. Então é possível afirmar que houve uma intensificação das relações comerciais entre os países do grupo. Mais precisamente, a participação da China nas exportações e importações dos países do grupo BRIS (BRICS sem a China) aumentou e adquiriu uma importância significativa que é demonstrada na figura 1.

Ao considerar a relevância desse aumento do fluxo China-BRIS, é válido supor que os produtos chineses adquiriram uma importância significativa para as demandas dos países do grupo BRIS. E uma vez que esses produtos foram absorvidos em grandes quantidades pelas economias desses países, é possível afirmar que a participação significativa dos produtos chineses nessas economias funciona como um determinante significativo para explicar um processo de homogeneização das estruturas de preferências das demandas dos países do BRIS. E mesmo que o comércio China-BRIS não seja tão relevante para a China, esse país também está incluído nesse processo, posto que, de acordo com a teoria pelo lado da demanda, um país procura exportar aquilo que já é conhecido e aceito em seu mercado interno.

Para ilustrar a suposição: se um determinado celular "A" chinês é amplamente comercializado na China, respondendo por uma grande fatia de seu mercado interno, existe uma maior probabilidade de que esse celular "A" obtenha sucesso ao ser exportado, principalmente se comparado com outro celular "B" que não foi lançado no mercado chinês. No caso do celular "A", existe um sólido conhecimento da estrutura de custos de sua produção em massa e um sucesso e aceitação por parte do público chinês.

A partir do momento em que esse celular "A" é exportado e é bem recebido pelo público de outro país, a participação do celular "A" nas vendas totais de celulares desse país tende a ser significante e semelhante com a participação de "A" nas vendas totais de celulares da China. Dessa forma, as preferências nas demandas por celulares nos dois países tendem a se homogeneizar à medida que a China intensifica as exportações do celular "A" para o outro país. O resumo da ilustração desse processo está na Figura 2. 


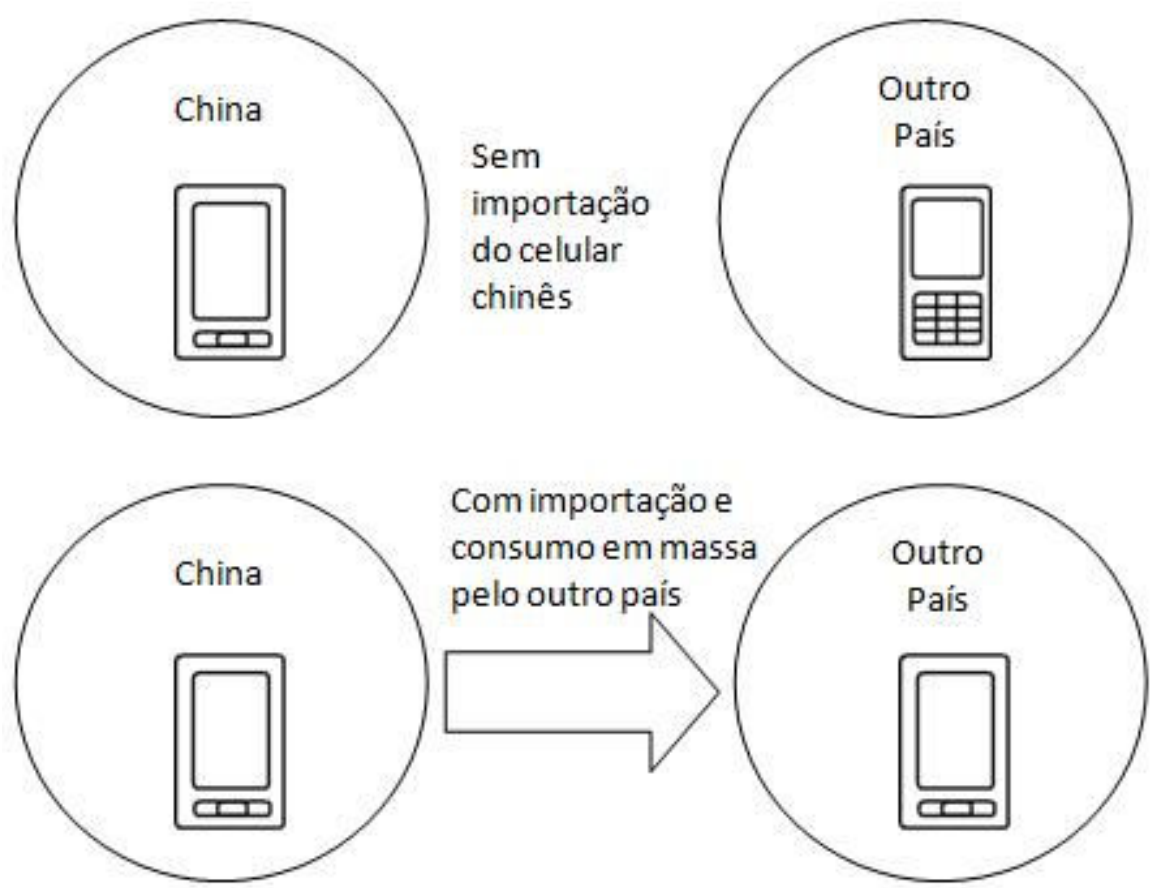

Figura 2 - Processo de homogeneização total das estruturas de preferência das demandas Elaborada pelo autor.

Esse fato acaba impulsionando o comércio entre os países. Portanto, é possível supor que existe uma relação endógena entre o aumento do comércio entre dois países e a homogeneização das preferências de suas demandas, ou seja, um pode determinar o outro.

Adicionalmente, os pontos em comum entre os países do grupo BRICS, apresentados no capítulo 2, também servem como argumentos para a tese de que esses países possuem um nível similar de desenvolvimento. Com isso, é possível afirmar que países com níveis similares de desenvolvimento tendem a apresentar demandas com preferências relativamente similares.

A partir desse cenário, é pressuposto que os países do BRICS passaram por um processo parcial de homogeneização de suas estruturas de preferências. Com essa homogeneização, o comércio entre eles tende a ficar mais viável, ceteris paribus. E essa homogeneização pode abrir oportunidades não somente para o comércio China-BRIS como também para o comércio entre os países do BRIS.

Com o comércio entre os países do grupo mais viável, existe uma tendência de que esses países prossigam com um processo de integração econômica entre eles. Parte dessa integração econômica crescente também pode ser explicada pelos processos de liberalização comercial que esses países passaram (vide subseções 2.1 e 2.2). 
A integração econômica intensificada acaba fortalecendo as estruturas de interdependência entre os países. E, como visto na subseção 2.2, a integração econômica contribui para a intensificação dos fluxos de capital entre os países, ou seja, para uma maior integração financeira entre os países que pode ser refletida na evolução dos desempenhos de seus mercados acionários que, devido às estruturas de interdependência, tendem a seguir direções semelhantes. Esse processo está resumido na Figura 3.

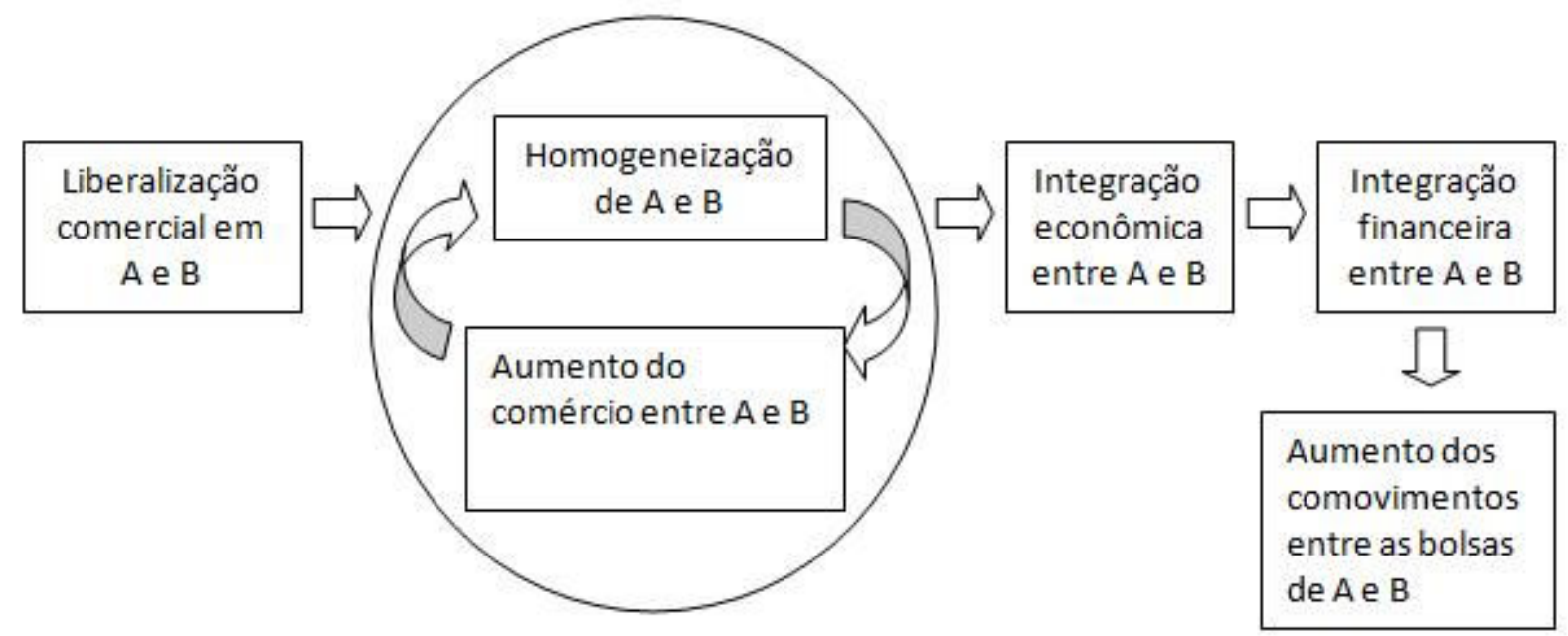

Figura 3 - Comovimentos entre bolsas de valores como reflexo do comércio entre os países A e B Elaborada pelo autor.

Portanto, no modelo elaborado, é pressuposto que os BRICS têm passado pelo processo descrito acima. E, assim, o nível da integração financeira entre esses países é interpretado como o resultado desse processo. E dentro do universo da integração financeira entre esses países, o modelo aborda somente um subconjunto desse universo: no caso, a integração dos mercados acionários dos BRICS. Portanto, a partir daqui, em toda menção à integração financeira será subentendido que se trata da integração entre os mercados acionários.

Similar aos trabalhos de Bracker (1999) e Securato e Oiveira (1998), o modelo utiliza o grau de comovimento entre esses mercados como proxy que busca representar a magnitude da integração financeira dentro do BRICS, sendo medido pela correlação linear entre os retornos desses mercados.

Para medir o nível de integração financeira, são utilizadas variáveis proxies que utilizam a evolução dos retornos dos índices para representar a evolução da integração financeira entre os mercados envolvidos. 
A primeira variável é o indicador Nível de Globalização Restrita (ou NGR) de Securato (1997) e Securato e Oliveira (1998). Esse índice considera a distância euclidiana entre todos os pontos distribuídos em um plano e esses pontos representam os valores dos retornos dos mercados em um determinado instante. O NGR, em um instante $t$, tem a fórmula:

$$
N G R=1-\sqrt{\frac{\sum_{i=1}^{N}\left(R_{i}-1\right)^{2}}{N}}
$$

Onde $R_{i}$ é a correlação entre os retornos dos índices dos mercados acionários dos países em um determinado intervalo de tempo, tomados dois a dois, e $N$ é o número de correlações. Quanto maior o NGR, que varia de 0 a 1 , maior é a integração entre os países.

Segundo Securato e Oliveira (1998), as vantagens do uso do NGR residem na sua simplicidade, objetividade e facilidade de obtenção de seus valores de entrada. Dentre as desvantagens, existem a representatividade e a abrangência limitadas, uma vez que os valores dos índices não captam os efeitos de todos os fluxos de recursos. O fato de não demonstrar as causas da integração também é interpretado como uma desvantagem desse indicador.

O intervalo de tempo determinado para o cálculo das correlações é de dois anos, do mesmo modo que ocorre em Santos e Coelho (2010). Assim, o primeiro valor de NGR para o ano de 2003 possui correlações que consideraram somente os retornos dos mercados dos BRICS que têm início em 2001 e vão até o fím de 2002. O segundo valor de NGR imediatamente posterior tem suas correlações com uma janela de tempo adiantada em um mês em comparação com o valor anterior e assim por diante. Com isso, tem-se uma série NGR de periodicidade mensal, denotada como $N G R_{t}$, que representa a evolução da integração financeira dentro dos BRICS. A formação da série é demonstrada na figura 4. 


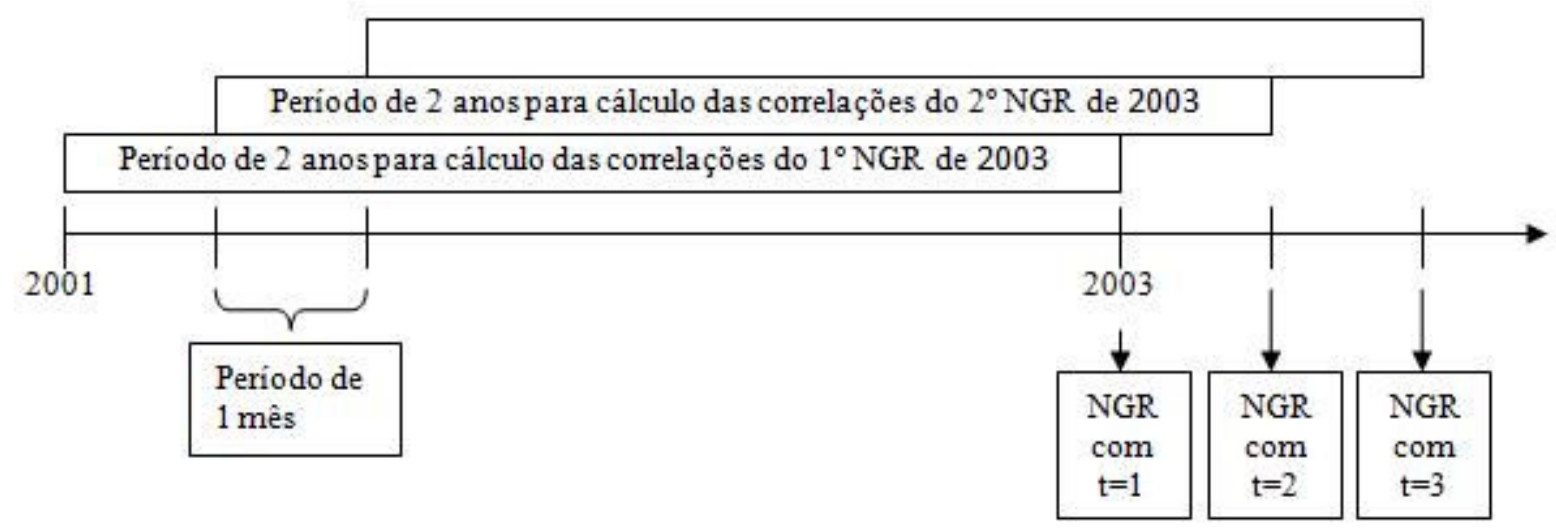

Figura 4 - Períodos considerados para obtenção da série de NGR

Elaborada pelo autor.

Ao observar a figura 4, fica evidente que a janela de tempo utilizada para a coleta de dados é maior que a janela utilizada para aplicação do modelo elaborado que vai de 2003 a 2011, focando, portanto, nos últimos oito anos.

A segunda variável utilizada é a correlação média, ou seja, a média aritmética simples das correlações entre os retornos dos mercados analisados, tomados dois a dois, como consta em Eun e Lee (2010).

A terceira variável é a distância risco-retorno média, desenvolvida por Eun e Lee (2010). O cálculo dessa medida segue os passos representados pelas fórmulas abaixo:

$$
\begin{gathered}
D R_{i t}=\left|\bar{R}_{i t}-\frac{1}{N} \sum_{i=1}^{N} \bar{R}_{i t}\right|, i=1, \ldots, N ; t=1, \ldots, T \text { (4) } \\
D S_{i t}=\left|S D_{i t}-\frac{1}{N} \sum_{i=1}^{N} S D_{i t}\right|, i=1, \ldots, N ; t=1, \ldots, T(5) \\
W(D R)=\sqrt{\sum_{i=1}^{N} \sum_{t=1}^{T} D R_{i t}^{2} /\left(\sum_{i=1}^{N} \sum_{t=1}^{T} D R_{i t}^{2}+\sum_{i=1}^{N} \sum_{t=1}^{T} D S_{i t}^{2}\right)} \\
W(D S)=\sqrt{\sum_{i=1}^{N} \sum_{t=1}^{T} D S_{i t}^{2} /\left(\sum_{i=1}^{N} \sum_{t=1}^{T} D R_{i t}^{2}+\sum_{i=1}^{N} \sum_{t=1}^{T} D S_{i t}^{2}\right)}(7) \\
D R S_{i t}=\sqrt{\left(D R_{i t} / W(D R)\right)^{2}+\left(D S_{i t} / W(D S)\right)^{2}}(8)
\end{gathered}
$$

Na equação 4, é medido o módulo da diferença entre a média dos retornos de um mercado e a média das médias de todos os $\mathrm{N}$ mercados analisados que aqui será chamada de distânciaretorno de um mercado ou $D R_{i t}$. 
Na equação 5, é medido o módulo da diferença entre o desvio-padrão dos retornos de um mercado e o desvio-padrão médio de todos os $\mathrm{N}$ mercados analisados que aqui será chamada de distância-risco de um mercado ou $D S_{i t}$.

As equações 6 e 7 calculam pesos para normalizar $D R_{i t}$ e $D S_{i t}$. Após isso, a raiz da soma dos quadrados das distâncias normalizadas produz a distância risco-retorno de um mercado ou $D R S_{i t}$. Por fim, a média das distâncias risco-retorno de cada um dos mercados em um determinado resulta na distância risco-retorno média. Diferente das outras variáveis, a interpretação é a de que quanto maior é o valor da DRR média, menor é o nível de integração entre os mercados analisados.

No caso da correlação média e da DRR média, o intervalo de tempo para cálculo das correlações, médias e desvios-padrão dos retornos são de seis meses, como utilizado em Eun e Lee (2010), e não de dois anos, como acontece com o NGR. Assim, a sistemática é a mesma que a da figura 4 , somente substituindo dois anos por seis meses.

\subsubsection{Pressupostos e modelagem do decoupling}

Inicialmente, para entender o modelo, é necessário visualizar o comércio entre os países do grupo BRICS como um comércio intrarregional. Assim, os países do BRICS formam uma região e qualquer outro país é visualizado fora dessa região. A partir disso, é pressuposto que o aumento do comércio "dentro" do BRICS, que resulta em uma maior integração financeira, diminui a dependência desses países em relação aos países desenvolvidos. E com a diminuição dessa dependência, os ciclos de negócios do BRICS tendem a ficar mais independentes dos ciclos de negócios dos países desenvolvidos, gerando uma situação de decoupling. E essa situação de decoupling acaba se refletindo nos mercados acionários à medida que esses refletem o que acontece na economia real.

Ao mesmo tempo, esse comércio entre os BRICS aumenta a dependência desses países entre si.

Nessa configuração, a integração financeira entre os BRICS funciona como a materialização de um "fator BRICS" semelhante ao fator regional de Kose et al (2012) apresentado na subseção 2.4. Paralelamente, existe o fator internacional que diz respeito ao mercado internacional que faz com que países emergentes e desenvolvidos dependam um do outro e caminhem juntos, com ciclos de negócios semelhantes. Assim, o decoupling entre o BRICS e 
os países desenvolvidos será maior à medida que o fator BRICS aumente seu impacto em relação ao fator internacional.

Fundamentalmente, esse fator BRICS representa o efeito da cooperação econômica entre os países do grupo. E a partir disso, busca-se testar o efeito dessa cooperação no mercado internacional. Essas ideias fundamentais podem ser visualizadas na Figura 5.

Antes da cooperação entre os BRICS:

Fator intemacional

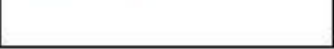

Depois da cooperação entre os BRICS:

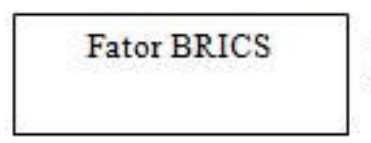

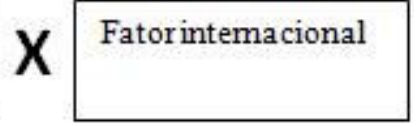

Figura 5 - Ideias fundamentais da conjectura
Resultado:

Todos os mercados caminham juntos

Mercados dos BRICS tendem a seguir caminhos diferentes dos outros Elaborada pelo autor.

Para a expressão matemática da relação de decoupling, é inicialmente proposta a construção de uma carteira de investimentos em que os ativos dessa carteira são representados pelos retornos dos índices que representam as bolsas de valores do grupo BRICS. A participação de cada índice na carteira é determinada segundo o valor da capitalização total de cada um dos mercados dos BRICS em 31 de outubro de 2012. E, assim, está calculada uma série de retornos dessa carteira que vai de 2003 a outubro de 2012. Essa série é simbolizada por $B R I C S_{t}$ e representa a evolução da performance de todos os mercados acionários dos BRICS.

Paralelo a isso, como já explicado na subseção 2.4, o principal parâmetro de desempenho utilizado para verificar se existe decoupling é o desempenho da economia dos Estados Unidos e, dentro do universo dos mercados de acionários, o desempenho de seus mercados acionários. Essa convenção também é adotada neste modelo.

Assim, sendo $E U A_{t}$ a série de retornos do índice que melhor representa a evolução do mercado acionário dos Estados Unidos, que também segue de 2003 a outubro de 2012, tem-se que o decoupling entre os desempenhos dos mercados dos BRICS e dos EUA, $D_{t}$, deriva da seguinte fórmula:

$$
D_{t}=\left|B R I C S_{t}-E U A_{t}\right|(9)
$$


Fica evidente que, a partir da equação 9, foi adotado o conceito de decoupling de independência (para detalhes desse conceito, ver subseção 2.4), ou seja, considera-se a diferença absoluta de desempenhos em que um alto valor de $D_{t}$ não necessariamente significa que os mercados acionários do grupo BRICS estão com um desempenho superior ao desempenho do mercado dos EUA. Assim, como será apresentado adiante, busca-se, fundamentalmente, analisar se os mercados possuem performances significativamente diferentes.

Uma limitação do modelo é que os setores representados nesses índices podem não ser exatamente os mesmos setores que estão se especializando diante de uma maior integração financeira observada. Portanto, o modelo se torna mais explicativo à medida que a relação entre mercado acionário e economia real se torna mais significativa, com um refletindo o outro.

Dessa forma, a conjectura desenvolvida pode ser expressa em:

$$
D_{t}=c+\gamma I F_{t}+e_{t}
$$

$\mathrm{Na}$ equação 10, é proposto que a integração financeira entre o grupo BRICS, ou $I F_{t}$, determina a magnitude do decoupling, $D_{t}$. Neste modelo, a integração financeira é representada pelas variáveis NGR, correlação média e DRR média. Além disso, $c$ é o intercepto da equação. A inclusão desse intercepto pressupõe um nível mínimo de decoupling que não é explicado pela integração entre os mercados dos BRICS. O parâmetro $\gamma$ mede quanto do valor das proxies para integração financeira pode explicar a magnitude de $D_{t}$. E os resíduos da equação, simbolizados por $e_{t}$, representam o valor do decoupling que não é explicado pela integração financeira e nem pela diferença mínima de desempenho $c$.

Assim, para o cálculo do modelo básico "A" os índices estarão dispostos para o cálculo de cada variável na estrutura presente no Quadro 6.

Quadro 6 - Índices utilizados no modelo “A” que será base de comparação

\begin{tabular}{|l|l|}
\hline Emprego dos índices utilizados & Índices utilizados \\
\hline $\begin{array}{l}\text { Para cálculo dos rendimentos da carteira BRICS (para } \\
\left.\text { cálculo de } D_{t}\right)\end{array}$ & $\begin{array}{l}\text { FTSE South Africa Index, IBrX, Shangai Se } \\
\text { Composite Index, Bombay Stock Exchange Index e } \\
\text { Russian RTS Index }\end{array}$ \\
\hline Parâmetro para cálculo de $D_{t}$ & S\&P500 \\
\hline $\begin{array}{l}\text { Para cálculo das variáveis que representam a a } \\
\text { integração entre os mercados do grupo BRICS }\left(I F_{t}\right)\end{array}$ & $\begin{array}{l}\text { FTSE South Africa Index, IBrX, Shangai Se } \\
\text { Composite Index, Bombay Stock Exchange Index e } \\
\text { Russian RTS Index }\end{array}$ \\
\hline
\end{tabular}


Para complementar a presente pesquisa, são propostos os modelos apresentados no Quadro 7.

Quadro 7 - Modelos gerais para estimação

\begin{tabular}{|c|l|}
\hline Modelo & Índices utilizados para os cálculos das variáveis do modelo geral \\
\hline $\mathrm{A}$ & Conjunto de índices que servirá como base de comparação \\
\hline $\mathrm{B}$ & Em relação a “A”, troca-se IBrX por Ibovespa \\
\hline $\mathrm{C}$ & Em relação a "A”, troca-se S\&P500 por MSCI World \\
\hline $\mathrm{D}$ & Em relação a “A”, exclui-se o índice chinês somente da variável dependente $D_{t}$ \\
\hline $\mathrm{E}$ & $\begin{array}{l}\text { Em relação a “A”, exclui-se o índice chinês da variável dependente } D_{t} \text { e das variáveis independentes } \\
I F_{t}\end{array}$ \\
\hline
\end{tabular}

Elaborado pelo autor.

O modelo "B" busca verificar se a troca do índice $\mathrm{IBrX}$ pelo Ibovespa pode produzir mudanças relevantes nos resultados, posto que o primeiro abrange um número maior de empresas do mercado acionário brasileiro.

O modelo "C" avalia se a integração financeira dos BRICS influencia o desempenho dos mercados acionários desses países em relação ao desempenho mundial.

O modelo "D" avalia se os desempenhos das bolsas do grupo BRIS (Brasil, Rússia, Índia e África do Sul) podem ser influenciados pela integração entre as bolsas desses países e a bolsa da China. Com isso, verifica-se o quanto a interação com a China pode influenciar o desempenho das bolsas do BRIS.

O modelo "E" avalia a relação proposta pelo modelo geral sem a China. Assim, é possível documentar e quantificar o impacto do mercado chinês na relação proposta quando se compara os resultados dos modelos "A", "D" e "E".

A avaliação do impacto do mercado chinês é proposta considerando o fato de que a China responde por quase metade do PIB do grupo (SANTOS, 2010).

Adicionalmente, para poder verificar os possíveis impactos da crise financeira de 2008 , os modelos citados são estimados antes e depois da ocorrência da crise. O intervalo definido como antes da crise se estende do início de 2003 até o fim de 2006, pois em 2007 já começa a crise nos EUA (DOOLEY, HUTCHINSON, 2009). E o intervalo definido como depois da crise se estende de outubro de 2009 a outubro de 2012.

O período entre início de 2007 e setembro de 2009 foi excluído da análise por apresentar valores interpretados como outliers, provavelmente referentes ao auge da crise, que 
demandam um número relevante de dummies para contornar seus efeitos nos modelos gerados, fato que acaba por fazer com que os modelos percam seu sentido teórico.

Para estimar o modelo da equação 10, o primeiro passo consistiu em verificar se as séries eram estacionárias. Para isso, essas séries foram submetidas ao teste da raiz unitária DickeyFuller aumentado (GUJARATI, 2006).

A possível existência de uma raiz unitária em alguma das séries pode levantar a necessidade de se verificar o risco de se produzir regressões espúrias ao se empregar séries não estacionárias no modelo (GRANGER, NEWBOLD, 1974). A solução mais comum para eliminar esse tipo de risco seria diferenciar as séries até que elas se tornem estacionárias (GUJARATI, 2006). Entretanto, quando se diferencia uma série, o modelo perde sua consistência teórica, uma vez que as séries não dizem mais respeito à pura evolução do fenômeno e sim à evolução das variações de curto prazo do fenômeno.

Considerando esses possíveis problemas, para regressões em que as duas séries não são estacionárias e possuem a mesma ordem: foi verificado se as séries $D_{t}$ e $I F_{t}$ são cointegradas. Se as séries das variáveis dependente e independente são cointegradas, isso significa que essas séries possuem uma tendência estocástica comum, com uma relação de equilíbrio no longo prazo cujos desvios são transitórios, e, portanto, a regressão não é espúria (ENGLE, GRANGER, 1987). Basicamente, as séries são cointegradas se os resíduos da regressão cointegrante são estacionários (GUJARATI, 2006). Dessa forma, os resíduos da regressão cointegrante foram submetidos ao teste ADF.

O teste de cointegração de Engle-Granger não é aconselhável para regressões em que a variável dependente é estacionária e a independente é estacionária em suas diferenças, uma vez que ele pressupõe que as duas variáveis sejam estacionárias em suas diferenças. Para isso, Baffes (1997) evidencia que regressões com essa configuração apresentam um desempenho satisfatório se, pelo menos, os valores previstos são estacionários como os valores observados da variável dependente. Assim, os valores previstos das regressões com essa configuração foram submetidos ao teste ADF.

O método usado para a estimação é o dos Mínimos Quadrados Ordinários (MQO). Também foi verificado se as equações estimadas atendem aos pressupostos do método MQO. Os 
modelos só foram considerados válidos para análises e conclusões a respeito das variáveis e da relação proposta se os pressupostos do método MQO fossem atendidos.

Para verificar o pressuposto da normalidade dos resíduos, os resíduos das equações estimadas foram submetidos ao teste Jarque-Bera.

Para verificar a existência de autocorrelação nos resíduos, os resíduos foram submetidos ao teste Breusch-Godfrey.

Para verificar a existência de heterocedasticidade, os resíduos foram submetidos ao teste de Breusch-Pagan-Godfrey.

Para a análise do poder explicativo do modelo e de cada uma das variáveis independentes, foram empregados os testes $\mathrm{F}$ e $\mathrm{t}$, respectivamente.

As hipóteses nulas dos testes utilizados seguem no Quadro 8.

Quadro 8 - Testes utilizados e suas respectivas hipóteses nulas

\begin{tabular}{|l|l|}
\hline Teste & Hipótese nula \\
\hline Dickey-Fuller aumentado (ADF) & A série não é estacionária (existe uma raiz unitária) \\
\hline Jarque-Bera (JB) & Os resíduos são normalmente distribuídos \\
\hline Breusch-Godfrey (BG) & Não há autocorrelação nos resíduos \\
\hline Breusch-Pagan-Godfrey (BPG) & Os resíduos não apresentam heterocedasticidade \\
\hline Teste F & Todos os coeficientes do modelo são iguais a zero \\
\hline Teste t & O coeficiente/constante é igual a zero \\
\hline
\end{tabular}

Quando pelo menos um dos pressupostos do método MQO não foi atendido, foi investigada a existência de valores outliers na variável dependente, por análise gráfica e por um processo de tentativa e erro, cujos efeitos foram contornados por inclusão de dummies referentes a esses outliers.

O melhor modelo, do ponto de vista de poder de explicação da variável dependente, será escolhido segundo o $\mathrm{R}^{2}$ ajustado do modelo, ou seja, quanto maior o valor do $\mathrm{R}^{2}$ ajustado, maior o poder de explicação do modelo.

Os detalhes sobre os conceitos referentes ao processo de estimação citados acima podem ser conferidos em Fávero et. al (2009) e Gujarati (2006). 


\section{ANÁLISE DOS RESULTADOS}

\subsection{Análise preliminar dos dados-base da pesquisa}

Para uma melhor comparação dos desempenhos das bolsas, foram calculados os retornos de seus respectivos índices e, em seguida, calculou-se a média aritmética simples, o desviopadrão e o coeficiente de variação. A última medida é obtida pela divisão do desvio-padrão pela média.

Tabela 9 - Análise preliminar dos retornos dos índices mensais de 2001 a outubro de 2012

\begin{tabular}{|l|l|l|l|}
\hline Índice - País & Média & Desvio-padrão & Coeficiente de variação \\
\hline IBrX_Brasil & 0,018592 & 0,107536896 & 5,784051 \\
\hline Ibovespa - Brasil & 0,015740 & 0,114098866 & 7,248951 \\
\hline RTSI1 - Rússia & 0,021818 & 0,103370855 & 4,737847 \\
\hline Sensex30 - Índia & 0,013850 & 0,089352499 & 6,451348 \\
\hline SHCOMP - China & 0,005359 & 0,082112607 & 15,32162 \\
\hline JALSH - África do Sul & 0,012773 & 0,076732603 & 6,007331 \\
\hline SPX - EUA & 0,001553 & 0,046166199 & 29,72467 \\
\hline MSCI Mundo & 0,001656 & 0,048716746 & 29,41312 \\
\hline \multicolumn{4}{|c|}{ Elaborada pelo autor. } \\
\hline
\end{tabular}

Os resultados apresentados na Tabela 9 retratam uma nítida diferença de desempenho entre os mercados acionários dos BRICS e dos EUA. Em comparação com a média de $0,15 \%$ dos EUA, a média das médias dos retornos das bolsas dos BRICS fica em torno de 1,45\% e 1,39\% quando calculado com o IBrX e quando calculado com o Ibovespa, respectivamente. Analisando o desvio-padrão, também é possível observar que existe uma diferença relevante em termos de risco entre os BRICS e os Estados Unidos cujo risco é menor que o de todos os outros BRICS.

O padrão muito similar ao dos EUA, desempenhado pelo índice mundial, pode ser explicado pelo fato de o mercado norteamericano compor em torno de $50 \%$ da carteira do índice, mas esse índice, em comparação com o SPX, apresenta maior rentabilidade e maior risco. Essas primeiras evidências estão de acordo com a maioria dos achados encontrados na literatura de finanças internacionais. Entretanto, essas evidências em uma análise preliminar ainda não são suficientes para defender a hipótese de um possível decoupling entre as bolsas dos BRICS e dos EUA.

Ao se analisar o coeficiente de variação, pode-se notar uma diferença nítida entre a bolsa chinesa e as bolsas dos outros BRICS em que o nível médio de rentabilidade do mercado 
chinês está mais próximo do nível do mercado estadunidense. Em termos de risco (desviopadrão), a bolsa chinesa está relativamente próxima dos outros BRICS.

É válido ressaltar a diferença entre os desempenhos dos índices Ibovespa e IBrX em que o primeiro possui menor retorno médio e maior risco.

Abaixo são apresentados os mesmos tipos de medidas para os log-retornos que serão usados como base para o cálculo das variáveis do modelo. De uma forma geral, os padrões apresentados na Tabela 10 são quase os mesmos já analisados na Tabela 9.

Tabela 10 - Análise preliminar dos log-retornos dos índices mensais de 2001 a outubro de 2012

\begin{tabular}{|l|l|l|l|}
\hline Índice - País & Média & Desvio-padrão & Coeficiente de variação \\
\hline IBrX_Brasil & 0,012850 & 0,107536896 & 8,368622 \\
\hline Ibovespa - Brasil & 0,009003 & 0,117311838 & 13,02999 \\
\hline RTSI1 - Rússia & 0,016221 & 0,105603886 & 6,510481 \\
\hline Sensex30 - Índia & 0,009830 & 0,089473413 & 9,102482 \\
\hline SHCOMP - China & 0,001977 & 0,082821230 & 41,88611 \\
\hline JALSH - África do Sul & 0,009731 & 0,078042901 & 8,019996 \\
\hline SPX - EUA & 0,000474 & 0,046872856 & 98,93402 \\
\hline MSCI Mundo & 0,000448 & 0,049657735 & 110,7702 \\
\hline
\end{tabular}

Com base nos valores de capitalização de mercado de cada país em dólar, as tabelas 11 e 12 apresentam o percentual de participação de cada índice do mercado acionário de cada país para a formação das carteiras BRICS e BRIS, respectivamente.

Pela Tabela 11, tem-se que o maior peso da carteira formada refere-se ao mercado chinês que tem a maior capitalização de mercado em outubro de 2012. E a menor participação corresponde ao mercado russo. A BMFBovespa apresenta o terceiro maior valor de capitalização. Com isso, vale ressaltar o grande peso que o continente asiático tem na carteira formada.

$\mathrm{Na}$ Tabela 12, ao se retirar a China, percebe-se que as participações ficam mais equilibradas com níveis de participação parecidos em que Brasil e Índia possuem em torno de 30\% e Rússia e África do Sul em torno de 20\%.

Tabela 11 - Participação por índice do mercado de cada país na carteira BRICS

\begin{tabular}{|l|c|}
\hline País & Participação na carteira \\
\hline Brasil & $18,49 \%$ \\
\hline Rússia & $12,20 \%$ \\
\hline Índia & $19,15 \%$ \\
\hline China & $36,84 \%$ \\
\hline África do Sul & $13,30 \%$ \\
\hline
\end{tabular}

Elaborada pelo autor. 
Tabela 12 - Participação por índice do mercado de cada país na carteira BRIS

\begin{tabular}{|l|c|}
\hline País & Participação na carteira \\
\hline Brasil & $29,28 \%$ \\
\hline Rússia & $19,32 \%$ \\
\hline Índia & $30,33 \%$ \\
\hline África do Sul & $21,06 \%$ \\
\hline
\end{tabular}

Elaborada pelo autor.

A Tabela 13 apresenta algumas estatísticas sobre os retornos das carteiras formadas que servirão de base para o cálculo da variável dependente. Da carteira base para a carteira que troca o índice IBrX pelo Ibovespa, percebe-se uma ligeira queda na média dos retornos e um aumento no desvio-padrão quando se utiliza o Ibovespa.

Quando se compara a carteira base com a carteira que não inclui a China, percebe-se que a carteira base possui uma média menor e um desvio-padrão menor. Desse fato, pode-se argumentar que a inclusão da China nitidamente diversifica o risco da carteira.

Tabela 13 - Análise preliminar dos retornos de 2003 a outubro de 2012 das carteiras formadas

\begin{tabular}{|l|l|c|c|}
\hline Carteira & Média & Desvio-padrão & Coeficiente de variação \\
\hline Base & 0,014224 & 0,072327 & 5,084994 \\
\hline Com Ibovespa & 0,013944 & 0,072777 & 5,219024 \\
\hline Sem China & 0,018266 & 0,082462 & 4,514392 \\
\hline
\end{tabular}

Elaborada pelo autor.

$\mathrm{Na}$ Tabela 14, ao se analisar os log-retornos das carteiras formadas, percebe-se que os mesmos padrões identificados na Tabela 13 foram mantidos.

Tabela 14 - Análise preliminar dos log-retornos de 2003 a outubro de 2012 das carteiras formadas

\begin{tabular}{|l|l|c|c|}
\hline Carteira & Média & Desvio-padrão & Coeficiente de variação \\
\hline Base & 0,01148 & 0,074002 & 6,446445 \\
\hline Com Ibovespa & 0,011171 & 0,074452 & 6,664634 \\
\hline Sem China & 0,014695 & 0,084029 & 5,718232 \\
\hline
\end{tabular}

Elaborada pelo autor.

\subsection{Análise preliminar das variáveis dos modelos}

Após a obtenção dos valores das variáveis dependentes e independentes para cada conjunto de indicadores, algumas estatísticas, calculadas por período, são apresentadas nas tabelas 15, 16, 17 e 18 para ajudar no entendimento da evolução dessas variáveis e dos fenômenos que elas representam na janela de tempo estudada. 
Tabela 15 - Análise preliminar da variável dependente de fevereiro de 2003 a outubro de 2012

\begin{tabular}{|l|l|c|c|}
\hline Decoupling & Média & Desvio-padrão & Coeficiente de variação \\
\hline Base - todo o período & 0,040784 & 0,03275 & 0,803015 \\
\hline Base - período 1 & 0,036153 & 0,028511 & 0,788643 \\
\hline Base - crise & 0,060444 & 0,039923 & 0,660501 \\
\hline Base - período 2 & 0,029134 & 0,021883 & 0,751112 \\
\hline Com Ibovespa - todo o período & 0,040819 & 0,032778 & 0,803003 \\
\hline Com Ibovespa - período 1 & 0,035848 & 0,028067 & 0,782942 \\
\hline Com Ibovespa - crise & 0,060329 & 0,039747 & 0,658834 \\
\hline Com Ibovespa - período 2 & 0,029734 & 0,023316 & 0,784169 \\
\hline Com MSCI Mundo - todo o período & 0,035617 & 0,029241 & 0,820989 \\
\hline Com MSCI Mundo - período 1 & 0,031808 & 0,024701 & 0,776568 \\
\hline Com MSCI Mundo - crise & 0,054102 & 0,03571 & 0,660059 \\
\hline Com MSCI Mundo - período 2 & 0,023969 & 0,019245 & 0,802929 \\
\hline Sem China - todo o período & 0,044971 & 0,036254 & 0,806159 \\
\hline Sem China - período 1 & 0,04477 & 0,031745 & 0,709069 \\
\hline Sem China - crise & 0,056981 & 0,046639 & 0,818503 \\
\hline
\end{tabular}

Elaborada pelo autor.

Na Tabela 15, sobre a variável dependente decoupling: quando se analisa o conjunto-base de índices, verifica-se um aumento relevante no decoupling durante a crise que depois é revertido para um nível menor que o período pré-crise e, inclusive, compreende um nível mais estável que o do período pré-crise. Essas observações contribuem para a defesa da tese de que a diferença entre os mercados acionários dos BRICS e dos EUA acentuou-se durante a crise. Entretanto, essa diferença caiu após a crise e, nesse período pós-crise, os mercados tendem a apresentar performances similares. Contudo, essas evidências ainda não respondem se o nível de decoupling medido nos períodos é significativo ou não.

Quando se substitui o índice SPX dos EUA pelo índice mundial, o decoupling medido é, em média, menor e mais estável. Esse padrão pode ser explicado pelo fato de o índice mundial englobar em sua composição o desempenho de bolsas de países com padrões mais similares aos países dos BRICS. Entretanto, os níveis médios de decoupling ainda são muito parecidos com os níveis de quando se aplica o índice SPX, demonstrando a influencia dos Estados Unidos no desempenho mundial.

No conjunto que não inclui a China, verifica-se que, com exceção do período de crise, o nível médio de decoupling é o maior entre todos os conjuntos. $\mathrm{O}$ desvio-padrão também é o maior registrado, demonstrando que a magnitude da relação de decoupling sem a China tende a se tornar maior, porém mais instável. 
Tabela 16 - Análise preliminar da variável independente correlação média de fevereiro de 2003 a outubro de 2012

\begin{tabular}{|l|l|c|c|}
\hline Correlação média & Média & Desvio-padrão & Coeficiente de variação \\
\hline Base - todo o período & 0,508333 & 0,257222 & 0,50601 \\
\hline Base - período 1 & 0,333512 & 0,266162 & 0,798059 \\
\hline Base - crise & 0,58031 & 0,193343 & 0,333172 \\
\hline Base - período 2 & 0,666208 & 0,138479 & 0,207862 \\
\hline Com Ibovespa - todo o período & 0,500486 & 0,262691 & 0,524871 \\
\hline Com Ibovespa - período 1 & 0,317994 & 0,270831 & 0,851685 \\
\hline Com Ibovespa - crise & 0,577352 & 0,192459 & 0,333348 \\
\hline Com Ibovespa - período 2 & 0,663744 & 0,13934 & 0,20993 \\
\hline Sem China - todo o período & 0,605139 & 0,275779 & 0,455729 \\
\hline Sem China - período 1 & 0,429793 & 0,292801 & 0,681261 \\
\hline Sem China - crise & 0,684485 & 0,232234 & 0,339283 \\
\hline Sem China - período 2 & 0,757107 & 0,133898 & 0,176855 \\
\hline
\end{tabular}

Por meio da Tabela 16, é possível verificar que, no conjunto-base, a correlação média salta a partir da crise, contudo, a sua variabilidade cai. Esse padrão de evolução está de acordo com a hipótese de integração financeira crescente, uma vez que o aumento da correlação média não é seguido de um aumento no desvio-padrão da correlação, fato que caracterizaria um nítido efeito contágio a partir da crise. Também, pela análise do coeficiente de variação, é possível verificar que o padrão no período pré-crise é nitidamente diferente do período pós-crise, servindo de evidência para o argumento de que a crise de 2008 contribuiu para uma quebra estrutural no padrão de integração financeira entre os BRICS.

No conjunto que não inclui a China, verifica-se que a correlação média é a maior em todos os períodos e a sua variabilidade também. Assim, é possível afirmar que a correlação média e a sua variabilidade diminuem com a inclusão do mercado acionário chinês, demonstrando a importância da China para diversificação de risco no caso de um portfólio com empresas dos BRICS.

Tabela 17 - Análise preliminar da variável independente DRR média de fevereiro de 2003 a outubro de 2012

\begin{tabular}{|l|l|c|c|}
\hline DRR média & Média & Desvio-padrão & Coeficiente de variação \\
\hline Base - todo o período & 0,051067 & 0,016913 & 0,331191 \\
\hline Base - período 1 & 0,047805 & 0,015488 & 0,323987 \\
\hline Base - crise & 0,060363 & 0,014911 & 0,247023 \\
\hline Base - período 2 & 0,046921 & 0,017515 & 0,373300 \\
\hline Com Ibovespa - todo o período & 0,04682 & 0,015608 & 0,333362 \\
\hline Com Ibovespa - período 1 & 0,044421 & 0,01577 & 0,355021 \\
\hline Com Ibovespa - crise & 0,055073 & 0,012247 & 0,222376 \\
\hline Com Ibovespa- período 2 & 0,042508 & 0,015646 & 0,368077 \\
\hline Sem China - todo o período & 0,057339 & 0,025267 & 0,440668 \\
\hline Sem China - período 1 & 0,053599 & 0,028602 & 0,533627 \\
\hline Sem China - crise & 0,061661 & 0,023786 & 0,385753 \\
\hline Sem China - período 2 & 0,058233 & 0,021743 & 0,373373 \\
\hline
\end{tabular}

Elaborada pelo autor. 
Na Tabela 17, o padrão observado no conjunto-base é de um salto momentâneo da distância risco-retorno média durante a crise. Outras observações importantes: o menor desvio-padrão verificado aparece justamente durante a crise e observa-se que, por essa variável, o menor nível de integração financeira é apresentado durante a crise, diferente do que diz a variável correlação média. Assim, pela DRR média, a convergência entre os desempenhos das bolsas é menor durante a crise.

Como a DRR média também leva em consideração a evolução da convergência em termos de risco, é possível supor que, em todo o período analisado, também é observado um aumento na integração financeira, como acontece com a correlação média, em que os níveis de risco dos mercados acionários dos BRICS também ficaram mais parecidos.

Quando se retira a China do conjunto, observa-se que a DRR média é maior e, dado que sua magnitude é inversamente proporcional ao nível de integração financeira, é possível afirmar que a China está relacionada com um nível maior de integração financeira, sendo o oposto do que acontece com a correlação média.

Até aqui fica nítido que quando a variável proxy para integração financeira inclui a evolução do risco dos mercados, os resultados podem ser diferentes dos usuais apurados só com a evolução da correlação.

Tabela 18 - Análise preliminar da variável independente NGR de fevereiro de 2003 a outubro de 2012

\begin{tabular}{|l|l|c|c|}
\hline NGR & Média & Desvio-padrão & Coeficiente de variação \\
\hline Base - todo o período & 0,487812 & 0,180520 & 0,370060 \\
\hline Base - período 1 & 0,323897 & 0,131207 & 0,405089 \\
\hline Base - crise & 0,544674 & 0,131876 & 0,242120 \\
\hline Base - período 2 & 0,645314 & 0,063325 & 0,098131 \\
\hline Com Ibovespa - todo o período & 0,482418 & 0,183444 & 0,380259 \\
\hline Com Ibovespa - período 1 & 0,314500 & 0,131723 & 0,418834 \\
\hline Com Ibovespa - crise & 0,541410 & 0,132717 & 0,245132 \\
\hline Com Ibovespa - período 2 & 0,643104 & 0,063764 & 0,099151 \\
\hline Sem China - todo o período & 0,630889 & 0,178000 & 0,282142 \\
\hline Sem China - período 1 & 0,452328 & 0,131217 & 0,290091 \\
\hline Sem China - crise & 0,718847 & 0,077833 & 0,108274 \\
\hline Sem China - período 2 & 0,779260 & 0,058000 & 0,074432 \\
\hline
\end{tabular}

Na Tabela 18, que diz respeito a variável Nível de Globalização Restrita, verificam-se padrões similares aos da variável correlação média. Um fato ainda não ressaltado é que, no conjunto que não inclui a China, os desempenhos durante a crise e depois da crise são relativamente parecidos, com uma maior estabilidade no segundo caso. 
De posse das séries das variáveis dependentes e independentes, o próximo passo consistiu em analisar a estacionariedade das séries, por meio do teste ADF, para que fosse possível verificar o risco de se produzir regressões espúrias. Vale ressaltar que as séries de resíduos produzidas pelas regressões fundamentais (sem dummies) foram diagnosticadas estacionárias. Esse fato já é um forte indício de que as regressões não são espúrias.

As tabelas de 19 a 21 resumem os resultados dos testes de estacionariedade para as séries das variáveis, revelando as ordens das séries das variáveis dependentes e independentes que orientam se é necessário usar algum procedimento para verificar se as regressões são espúrias. A regra adotada é: quando as ordens são iguais a 1, utiliza-se o teste de cointegração de Engle-Granger; e quando as ordens são diferentes, com a variável dependente sendo estacionária, é verificado se os valores previstos são estacionários, como proposto em Baffes (1997).

A análise da Tabela 19, por exemplo, se dá da seguinte forma: a regressão A1 inclui as variáveis calculadas com os índices do modelo geral A no período anterior à crise de $2008 \mathrm{em}$ que a variável independente $I F_{t}$ é a correlação média. Da regressão A1 para a A2, a mudança se encontra no período abrangido que passa a ser depois da crise de 2008.

Também é necessário salientar que as 10 variáveis dependentes são as mesmas para as três tabelas. O que muda de uma tabela para outra é a variável independente que pode ser a correlação média, a distância risco-retorno média ou o NGR. Assim, seguem abaixo as tabelas que versam sobre a estacionariedade das séries das regressões. 
Tabela 19 - Controle de estacionariedade das regressões com a correlação média como variável independente

\begin{tabular}{|c|c|c|c|}
\hline Regressão & $D_{t}$ Ordem & $I F_{t}$ Ordem & Procedimento \\
\hline A1 & 0 & 1 & Análise dos valores previstos \\
\hline A2 & 0 & 1 & Análise dos valores previstos \\
\hline B1 & 0 & 1 & Análise dos valores previstos \\
\hline B2 & 0 & 1 & Análise dos valores previstos \\
\hline C1 & 0 & 1 & Análise dos valores previstos \\
\hline C2 & 0 & 1 & Análise dos valores previstos \\
\hline D1 & 0 & 1 & Análise dos valores previstos \\
\hline D2 & 1 & 1 & Teste de cointegração de Engle-Granger \\
\hline E1 & 0 & 1 & Análise dos valores previstos \\
\hline & 1 & 1 & \\
\hline
\end{tabular}

Elaborada pelo autor. 
Tabela 20 - Controle de estacionariedade das regressões com a DRR média como variável independente

\begin{tabular}{|c|c|c|c|}
\hline Regressão & $D_{t}$ Ordem & $I F_{t}$ Ordem & Procedimento \\
\hline A1 & 0 & 0 & Nenhum \\
\hline A2 & 0 & 1 & Análise dos valores previstos \\
\hline B1 & 0 & 0 & Nenhum \\
\hline $\mathrm{B} 2$ & 0 & 1 & Análise dos valores previstos \\
\hline $\mathrm{C} 1$ & 0 & 0 & Nenhum \\
\hline $\mathrm{C} 2$ & 0 & 1 & Análise dos valores previstos \\
\hline D1 & 0 & 0 & Nenhum \\
\hline D2 & 1 & 1 & Teste de cointegração de Engle-Granger \\
\hline E1 & 0 & 0 & Nenhum \\
\hline E2 & 1 & 1 & Teste de cointegração de Engle-Granger \\
\hline
\end{tabular}

Elaborada pelo autor. 
Tabela 21 - Controle de estacionariedade das regressões com o NGR como variável independente

\begin{tabular}{|c|c|c|c|}
\hline Regressão & $D_{t}$ Ordem & $I F_{t}$ Ordem & Procedimento \\
\hline A1 & 0 & 1 & Análise dos valores previstos \\
\hline A2 & 0 & 1 & Análise dos valores previstos \\
\hline B1 & 0 & 1 & Análise dos valores previstos \\
\hline $\mathrm{B} 2$ & 0 & 1 & Análise dos valores previstos \\
\hline $\mathrm{C} 1$ & 0 & 1 & Análise dos valores previstos \\
\hline $\mathrm{C} 2$ & 0 & 1 & Análise dos valores previstos \\
\hline D1 & 0 & 1 & Análise dos valores previstos \\
\hline D2 & 1 & 1 & Teste de cointegração de Engle-Granger \\
\hline E1 & 0 & 1 & Análise dos valores previstos \\
\hline E2 & 1 & 1 & Teste de cointegração de Engle-Granger \\
\hline
\end{tabular}

Após a realização do controle da estacionariedade, foi diagnosticado que as regressões D1 e E1 das tabelas 19 e 21 podem apresentar desempenhos não satisfatórios e, por isso, essas regressões foram excluídas da análise. Para as outras regressões, ficou validado o uso do método MQO.

Dado que as séries de decoupling sem a China no período 2 são estacionárias em diferenças, foram testados para essas séries os modelos $\mathrm{AR}(1), \mathrm{AR}(2), \mathrm{MA}(1)$ e $\mathrm{MA}(2)$ e o único que foi significativo foi o modelo AR(2). Portanto, a defasagem de dois meses da série em questão foi incluída como variável independente em todos os modelos em que a série foi empregada como será apresentado mais adiante.

\subsection{Análise dos modelos estimados}

Nas tabelas de 22 a 47, são apresentados os resultados dos testes referentes aos modelos rodados. 
Tabela 22 - Resultados da regressão 1: decoupling no período 1, explicado pela correlação média, de acordo com o modelo geral $A$

\begin{tabular}{|c|c|l|c|}
\hline Jarque-Bera (prob.) & 0,354770 & $\mathrm{R}^{2}$ ajustado & 0,305202 \\
\hline BPG (prob.) & 0,0720 & Estatística F & 7,735423 \\
\hline Breusch-Godfrey (prob.) & 0,7048 & Estatística F (prob.) & 0,000306 \\
\hline Variável & \multicolumn{1}{c|}{ Coeficiente } & Estatística t & Probabilidade \\
Correlação Média P1 & 0,031550 & 2,329613 & 0,0246 \\
D36 & 0,049029 & 1,984025 & 0,0537 \\
D47 & 0,082115 & 3,416887 & 0,0014 \\
Constante & 0,022840 & 4,041376 & 0,0002 \\
\hline
\end{tabular}

Elaborada pelo autor.

Tabela 23 - Resultados da regressão 2: decoupling no período 2, explicado pela correlação média, de acordo com o modelo geral $A$

\begin{tabular}{|c|c|l|c|}
\hline Jarque-Bera (prob.) & 0,544551 & $\mathrm{R}^{2}$ ajustado & 0,420707 \\
\hline BPG (prob.) & 0,1117 & Estatística F & 6,228951 \\
\hline Breusch-Godfrey (prob.) & 0,3903 & Estatística F (prob.) & 0,000416 \\
\hline Variável & Coeficiente & Estatística t & Probabilidade \\
Correlação Média P2 & 0,052998 & 2,388956 & 0,0232 \\
D12 & $-0,033745$ & $-1,963176$ & 0,0587 \\
D16 & 0,044240 & 2,600315 & 0,0141 \\
D25 & $-0,036554$ & $-2,071245$ & 0,0467 \\
D30 & 0,052952 & 2,994235 & 0,0054 \\
Constante & $-0,006900$ & $-0,467580$ & 0,6434 \\
\hline
\end{tabular}

Elaborada pelo autor.

Em primeiro lugar, na Tabela 22, o resultado do teste Jarque-Bera (JB) não rejeita a hipótese de normalidade dos resíduos. O teste de Breusch-Pagan-Godfrey (BPG) demonstra que os resíduos são homocedásticos a um nível de significância maior que 5\%. O teste de BreuschGodfrey (BG) sugere que não há autocorrelação nos resíduos e o teste F sugere que o modelo possui pelo menos um coeficiente/constante diferente de zero. Compilando somente esses resultados, é possível afirmar que o modelo gerado é relativamente robusto e confiável para explicar a relação entre a variável dependente e as independentes. Essa robustez é observada em todos os modelos apresentados nessa subseção.

Ainda na Tabela 22, o coeficiente da correlação média foi positivo e significativo a $5 \%$, sugerindo que a integração entre os mercados acionários dos BRICS foi importante na explicação da relação de decoupling entre esses e o mercado dos EUA. As dummies encontradas, D36 e D47, que contribuíram para aumentar a relação de decoupling referem-se às datas 31/01/2006 e 29/12/2006, respectivamente. Não foram identificados eventos especiais com relação a essas datas que possam ter um impacto nos mercados analisados. $\mathrm{O}$ fato de a constante ser positiva e significativa a $1 \%$ revela uma forte evidência de que existe um nível mínimo de decoupling, ou seja, os desempenhos das bolsas dos BRICS foram significativamente diferentes do desempenho da bolsa dos EUA no período 1, defendendo a hipótese de decoupling absoluto entre esses mercados. 
$\mathrm{Na}$ Tabela 23, o coeficiente da correlação média também foi positivo e significativo a $5 \%$ na explicação da variável decoupling. As dummies encontradas, D12, D16, D25 e D30, referemse, respectivamente, às datas 30/09/2010, 31/01/2011, 31/10/2011 e 30/03/2012. Com exceção da data 31/10/2011, não foram identificados eventos especiais com relação a essas datas que possam ter um impacto nos mercados analisados. A dummy D25 pode estar relacionada à notícia de desemprego recorde na zona do euro no mês anterior, com uma consequente alta do dólar. Diferente do período 1, a constante não é significativa no período 2, sugerindo que não existe evidência de decoupling significativo entre os mercados dos BRICS e dos EUA nos últimos 3 anos.

Tabela 24 - Resultados da regressão 3: decoupling no período 1, explicado pela distância risco-retorno média, de acordo com o modelo geral $A$

\begin{tabular}{|c|c|l|c|}
\hline Jarque-Bera (prob.) & 0,274311 & $\mathrm{R}^{2}$ ajustado & 0,256830 \\
\hline BPG (prob.) & 0,1170 & Estatística F & 6,299007 \\
\hline Breusch-Godfrey (prob.) & 0,7921 & Estatística F (prob.) & 0,001224 \\
\hline Variável & Coeficiente & Estatística t & Probabilidade \\
DRR Média P1 & $-0,353001$ & $-1,508331$ & 0,1388 \\
D36 & 0,061734 & 2,483709 & 0,0170 \\
D47 & 0,080851 & 3,253431 & 0,0022 \\
Constante & 0,049994 & 4,241841 & 0,0001 \\
\hline
\end{tabular}

Elaborada pelo autor.

Tabela 25 - Resultados da regressão 4: decoupling no período 2, explicado pela distância risco-retorno média, de acordo com o modelo geral $A$

\begin{tabular}{|c|c|c|c|}
\hline Jarque-Bera (prob.) & 0,673432 & $\mathrm{R}^{2}$ ajustado & 0,382144 \\
\hline BPG (prob.) & 0,3780 & Estatística F & 6,566512 \\
\hline Breusch-Godfrey (prob.) & 0,5191 & Estatística F (prob.) & 0,000563 \\
\hline Variável & Coeficiente & Estatística t & Probabilidade \\
\hline DRR Média P2 & 0,365406 & 2,165468 & 0,0379 \\
\hline D16 & 0,037894 & 2,166378 & 0,0378 \\
\hline D25 & $-0,031294$ & $-1,757833$ & 0,0883 \\
\hline D30 & 0,060714 & 3,443767 & 0,0016 \\
\hline Constante & 0,010170 & 1,230131 & 0,2276 \\
\hline
\end{tabular}

Elaborada pelo autor.

Pela análise da Tabela 24, é possível verificar que, quando a proxy para integração financeira é a DRR média, a integração financeira não é significativa na explicação da relação de decoupling no período 1. Portanto, no período 1 , com base nesse resultado, a relação de decoupling é melhor explicada pela covariação de retornos dos mercados dos BRICS (captada pela correlação média e pela DRR média) e não pela covariação de níveis de risco desses mercados (captada somente pela DRR média). Assim, dentro do espectro da integração entre os mercados acionários dos BRICS, pode-se conjecturar que os padrões de covariação de retornos e de covariação das volatilidades desses mercados são diferentes no período 1. 
Na Tabela 25, o coeficiente da variável DRR média é significativo a 5\%, porém o seu sinal positivo sugere que quanto maior o nível de integração financeira (inversamente proporcional à DRR média), menor a magnitude da relação de decoupling no período 2. Portanto, trata-se de uma interpretação oposta à sugerida na análise da correlação média no mesmo período. Mas, independente do sinal do coeficiente da variável, é válido ressaltar que nesse período, a covariação das volatilidades entra no grupo de fatores com significativo poder de explicação da magnitude da relação de decoupling, uma vez que está dentro da construção da variável DRR média.

Outro fato importante relativo à Tabela 25 é que a variável D12 não é significativa como acontece com o modelo que emprega a correlação média.

Tabela 26 - Resultados da regressão 5: decoupling no período 1, explicado pelo nível de globalização restrita, de acordo com o modelo geral $\mathbf{A}$

\begin{tabular}{|c|c|l|c|}
\hline Jarque-Bera (prob.) & 0,174951 & $\mathrm{R}^{2}$ ajustado & 0,228534 \\
\hline BPG (prob.) & 0,2617 & Estatística F & 5,542243 \\
\hline Breusch-Godfrey (prob.) & 0,4888 & Estatística F (prob.) & 0,002627 \\
\hline Variável & Coeficiente & Estatística t & Probabilidade \\
NGR P1 & 0,023025 & 0,783862 & 0,4374 \\
D36 & 0,057347 & 2,192952 & 0,0338 \\
D47 & 0,077992 & 3,043235 & 0,0040 \\
Constante & 0,025815 & 2,578251 & 0,0134 \\
\hline
\end{tabular}

Elaborada pelo autor.

Tabela 27 - Resultados da regressão 6: decoupling no período 2, explicado pelo nível de globalização restrita, de acordo com o modelo geral $\mathrm{A}$

\begin{tabular}{|c|c|c|c|}
\hline Jarque-Bera (prob.) & 0,316916 & $\mathrm{R}^{2}$ ajustado & 0,299704 \\
\hline BPG (prob.) & 0,5207 & Estatística F & 6,135620 \\
\hline Breusch-Godfrey (prob.) & 0,5877 & Estatística F (prob.) & 0,001960 \\
\hline Variável & Coeficiente & Estatística t & Probabilidade \\
\hline NGR P2 & 0,051525 & 0,997101 & 0,3260 \\
\hline D16 & 0,047011 & 2,412446 & 0,0216 \\
\hline D30 & 0,062885 & 3,312686 & 0,0022 \\
\hline Constante & $-0,007086$ & $-0,211251$ & 0,8340 \\
\hline
\end{tabular}

Elaborada pelo autor.

Analisando as tabelas 26 e 27, verifica-se que a variável NGR não foi significativa para explicar a evolução do decoupling. Outra observação que merece destaque é que, em comparação com o modelo que emprega correlação média, as variáveis D12 e D25 perderam poder significativo de explicação.

Nesse primeiro conjunto de modelos que compreende as tabelas 22 a 27, verificou-se que, pela análise do $\mathrm{R}^{2}$ ajustado, os modelos que abordam o período 2 foram mais explicativos e os modelos que empregam a correlação média, tanto no período 1 como no período 2 , foram 
mais explicativos. Também é observável que a magnitude da influência da integração entre os mercados acionários dos BRICS depende de qual proxy está representando o nível de integração financeira. De acordo com os resultados apresentados até aqui, existem evidências de que a convergência dos desempenhos das bolsas dos BRICS, que representa o resultado da intensificação dos fluxos de capital entre esses mercados (integração), impacta a sincronia entre os ciclos dessas bolsas e os ciclos da bolsa dos EUA. Colocado de outra forma, existem indícios de que a integração financeira entre as bolsas dos BRICS impacta a dependência dessas em relação ao mercado acionário norteamericano.

Além disso, de 2003 a 2006, existem evidências de que existiu um nível de decoupling significativo entre os desempenhos das bolsas dos BRICS e dos EUA, independente da influência da integração financeira, ou seja, existiram claras oportunidades de diversificação internacional para carteiras de investimento que incluíssem empresas das bolsas dos BRICS e dos EUA.

Entretanto, é possível que esse decoupling significativo tenha desaparecido depois da crise. Assim, a crise financeira de 2008 teve um efeito negativo na magnitude do decoupling em questão, isto é, os desempenhos das bolsas dos BRICS e dos EUA convergiram a ponto de a diferença mínima entre os desempenhos dessas bolsas não ser significativa.

Agora seguem os modelos com alterações em algum dos índices utilizados nesse modelo geral "A" para verificar se acontecem mudanças relevantes em relação ao que já foi abordado até aqui. O primeiro conjunto alternativo de índices, que corresponde ao modelo geral "B", substitui o índice IBrX pelo Ibovespa.

Tabela 28 - Resultados da regressão 7: decoupling no período 1, explicado pela correlação média, de acordo com o modelo geral $B$

\begin{tabular}{|c|c|l|c|}
\hline Jarque-Bera (prob.) & 0,330550 & $\mathrm{R}^{2}$ ajustado & 0,285381 \\
\hline BPG (prob.) & 0,1178 & Estatística F & 7,123332 \\
\hline Breusch-Godfrey (prob.) & 0,5802 & Estatística F (prob.) & 0,000547 \\
\hline Variável & Coeficiente & Estatística t & Probabilidade \\
Correlação Média P1 & 0,029798 & 2,241147 & 0,0302 \\
D36 & 0,043841 & 1,775866 & 0,0828 \\
D47 & 0,080632 & 3,360783 & 0,0016 \\
Constante & 0,023725 & 4,373986 & 0,0001 \\
\hline
\end{tabular}


Tabela 29 - Resultados da regressão 8: decoupling no período 2, explicado pela correlação média, de acordo com o modelo geral $B$

\begin{tabular}{|c|c|l|c|}
\hline Jarque-Bera (prob.) & 0,631659 & $\mathrm{R}^{2}$ ajustado & 0,413779 \\
\hline BPG (prob.) & 0,0686 & Estatística F & 6,082060 \\
\hline Breusch-Godfrey (prob.) & 0,3055 & Estatística F (prob.) & 0,000492 \\
\hline Variável & Coeficiente & Estatística t & Probabilidade \\
Correlação Média P2 & 0,061001 & 2,583917 & 0,0147 \\
D12 & $-0,035044$ & $-1,901056$ & 0,0666 \\
D16 & 0,044947 & 2,466390 & 0,0194 \\
D25 & $-0,040622$ & $-2,152650$ & 0,0392 \\
D30 & 0,053409 & 2,813450 & 0,0084 \\
Constante & $-0,011368$ & $-0,726561$ & 0,4729 \\
\hline
\end{tabular}

Elaborada pelo autor.

Na Tabela 28, de uma forma geral, as variáveis independentes perderam poder de explicação quando comparamos com os resultados da Tabela 22. Entretanto, a constante ficou mais significativa. Na Tabela 29, em comparação com a Tabela 23, fica visível que a correlação média é mais explicativa quando se troca o IBrX pelo Ibovespa na análise.

Tabela 30 - Resultados da regressão 9: decoupling no período 1, explicado pela distância risco-retorno média, de acordo com o modelo geral $B$

\begin{tabular}{|c|c|l|c|}
\hline Jarque-Bera (prob.) & 0,284206 & $\mathrm{R}^{2}$ ajustado & 0,274566 \\
\hline BPG (prob.) & 0,0624 & Estatística F & 6,803428 \\
\hline Breusch-Godfrey (prob.) & 0,6756 & Estatística F (prob.) & 0,000745 \\
\hline Variável & Coeficiente & Estatística t & Probabilidade \\
DRR Média P1 & $-0,464693$ & $-2,075272$ & 0,0440 \\
D36 & 0,054181 & 2,238377 & 0,0304 \\
D47 & 0,078285 & 3,237588 & 0,0023 \\
Constante & 0,053672 & 5,060378 & 0,0000 \\
\hline
\end{tabular}

Elaborada pelo autor.

Tabela 31 - Resultados da regressão 10: decoupling no período 2, explicado pela distância risco-retorno média, de acordo com o modelo geral $B$

\begin{tabular}{|c|c|c|c|}
\hline Jarque-Bera (prob.) & 0,706616 & $\mathrm{R}^{2}$ ajustado & 0,383177 \\
\hline BPG (prob.) & 0,4014 & Estatística F & 6,590887 \\
\hline Breusch-Godfrey (prob.) & 0,4080 & Estatística F (prob.) & 0,000549 \\
\hline Variável & Coeficiente & Estatística t & Probabilidade \\
\hline DRR Média P2 & 0,488389 & 2,410113 & 0,0219 \\
\hline D16 & 0,039104 & 2,103312 & 0,0434 \\
\hline D25 & $-0,036256$ & $-1,904308$ & 0,0659 \\
\hline D30 & 0,060964 & 3,232084 & 0,0028 \\
\hline Constante & 0,007249 & 0,808690 & 0,4247 \\
\hline
\end{tabular}

Elaborada pelo autor.

O principal destaque da Tabela 30 é o fato de o coeficiente da variável DRR média ser significativo no período 1, diferente do que acontece quando se usa o IBrX (vide Tabela 24). Diferente do que acontece no período 2, o sinal do coeficiente da variável em questão é negativo, estabelecendo uma relação de proporcionalidade entre integração financeira e decoupling. Diante desse resultado, é possível afirmar que existem indícios de que a 
convergência de retornos e a convergência de volatilidades (base da variável DRR média) exercem um efeito que amplia a magnitude da relação de decoupling no período 1 .

De posse dos resultados da Tabela 31, o fato mais importante é essa mudança de sinal da variável DRR média do período 1 para o período 2. Assim, pelos resultados dos modelos das tabelas 27 e 28, tem-se a interpretação de que a integração financeira entre os BRICS tem a sua influência sobre a relação de decoupling modificada após a crise.

Tabela 32 - Resultados da regressão 11: decoupling no período 1, explicado pelo nível de globalização restrita, de acordo com o modelo geral $B$

\begin{tabular}{|c|c|c|c|}
\hline Jarque-Bera (prob.) & 0,164695 & $\mathrm{R}^{2}$ ajustado & 0,213019 \\
\hline BPG (prob.) & 0,2601 & Estatística F & 5,150398 \\
\hline Breusch-Godfrey (prob.) & 0,3563 & Estatística F (prob.) & 0,003940 \\
\hline Variável & Coeficiente & Estatística t & Probabilidade \\
\hline NGR P1 & 0,022697 & 0,779144 & 0,4402 \\
\hline D36 & 0,051862 & 1,995255 & 0,0524 \\
\hline D47 & 0,076468 & 2,995592 & 0,0045 \\
\hline Constante & 0,025980 & 2,685493 & 0,0102 \\
\hline
\end{tabular}

Elaborada pelo autor.

Tabela 33 - Resultados da regressão 12: decoupling no período 2, explicado pelo nível de globalização restrita, de acordo com o modelo geral $B$

\begin{tabular}{|c|c|l|c|}
\hline Jarque-Bera (prob.) & 0,310715 & $\mathrm{R}^{2}$ ajustado & 0,283654 \\
\hline BPG (prob.) & 0,4735 & Estatística F & 5,751690 \\
\hline Breusch-Godfrey (prob.) & 0,5818 & Estatística F (prob.) & 0,002798 \\
\hline Variável & Coeficiente & Estatística t & Probabilidade \\
NGR P2 & 0,062387 & 1,128219 & 0,2674 \\
D16 & 0,048671 & 2,316729 & 0,0269 \\
D30 & 0,064839 & 3,171270 & 0,0033 \\
Constante & $-0,013455$ & $-0,376091$ & 0,7093 \\
\hline
\end{tabular}

Elaborada pelo autor.

Nas tabelas 32 e 33, percebe-se que os padrões gerais observados foram os mesmos que os encontrados nas tabelas 26 e 27.

Ao se usar esse segundo conjunto de índices, percebe-se que a simples troca do índice $\mathrm{IBrX}$ pelo Ibovespa pode produzir mudanças significativas na análise. Com exceção dos modelos que empregam a DRR média, os modelos obtiveram um $\mathrm{R}^{2}$ ajustado maior quando utilizaram o IBrX na construção das variáveis.

Abaixo seguem os resultados relativos aos modelos que mantêm as variáveis independentes com os mesmos índices utilizados no modelo geral “A”, mas, no cálculo da variável dependente, o índice SPX é substituído pelo índice MSCI Mundo que mede o desempenho do mercado acionário mundial (modelo geral "C"). Assim, a relação de decoupling estabelecida 
avalia a sincronia entre os desempenhos dos mercados acionários dos BRICS e do mercado acionário mundial.

Tabela 34 - Resultados da regressão 13: decoupling no período 1, explicado pela correlação média, de acordo com o modelo geral $\mathbf{C}$

\begin{tabular}{|c|c|l|c|}
\hline Jarque-Bera (prob.) & 0,378150 & $\mathrm{R}^{2}$ ajustado & 0,330077 \\
\hline BPG (prob.) & 0,1404 & Estatística F & 8,554877 \\
\hline Breusch-Godfrey (prob.) & 0,8162 & Estatística F (prob.) & 0,000144 \\
\hline Variável & Coeficiente & Estatística t & Probabilidade \\
Correlação Média P1 & 0,027643 & 2,399275 & 0,0208 \\
D36 & 0,036702 & 1,745824 & 0,0880 \\
D47 & 0,079177 & 3,872771 & 0,0004 \\
Constante & 0,020124 & 4,185591 & 0,0001 \\
\hline
\end{tabular}

Elaborada pelo autor.

Tabela 35 - Resultados da regressão 14: decoupling no período 2, explicado pela correlação média, de acordo com o modelo geral $\mathbf{C}$

\begin{tabular}{|c|c|l|c|}
\hline Jarque-Bera (prob.) & 0,342300 & $\mathrm{R}^{2}$ ajustado & 0,268965 \\
\hline BPG (prob.) & 0,2727 & Estatística F & 5,415078 \\
\hline Breusch-Godfrey (prob.) & 0,8717 & Estatística F (prob.) & 0,003845 \\
\hline Variável & Coeficiente & Estatística t & Probabilidade \\
Correlação Média P2 & $-0,002537$ & $-0,122504$ & 0,9032 \\
D16 & 0,044984 & 2,676381 & 0,0115 \\
D30 & 0,051547 & 2,976573 & 0,0054 \\
Constante & 0,023050 & 1,646105 & 0,1092 \\
\hline
\end{tabular}

Elaborada pelo autor.

Na Tabela 34, em comparação com o conjunto-base de índices (modelo geral “A”), é notável que a correlação média aumentou ligeiramente seu poder de explicação. Também é importante o fato de a constante também ser significativa, sugerindo que o desempenho das bolsas dos BRICS foram significativamente diferentes do desempenho mundial como um todo no período 1, configurando uma evidência de outro tipo de decoupling.

$\mathrm{Na}$ Tabela 35, vale ressaltar que, diferente do que acontece no modelo parâmetro de comparação na Tabela 22, a correlação média não possui coeficiente significativo no período 2. Além disso, os coeficientes das variáveis D12 e D25 não são significativos, demonstrando que seus eventos podem estar associados com a evolução do mercado acionário dos Estados Unidos. 
Tabela 36 - Resultados da regressão 15: decoupling no período 1, explicado pela distância risco-retorno média, de acordo com o modelo geral $\mathbf{C}$

\begin{tabular}{|c|c|l|c|}
\hline Jarque-Bera (prob.) & 0,343020 & $\mathrm{R}^{2}$ ajustado & 0,269535 \\
\hline BPG (prob.) & 0,1913 & Estatística F & 6,657850 \\
\hline Breusch-Godfrey (prob.) & 0,7600 & Estatística F (prob.) & 0,000859 \\
\hline Variável & Coeficiente & Estatística t & Probabilidade \\
DRR Média P1 & $-0,263288$ & $-1,309759$ & 0,1972 \\
D36 & 0,047930 & 2,245063 & 0,0300 \\
D47 & 0,078102 & 3,658979 & 0,0007 \\
Constante & 0,041713 & 4,120524 & 0,0002 \\
\hline
\end{tabular}

Elaborada pelo autor.

Tabela 37 - Resultados da regressão 16: decoupling no período 2, explicado pela distância risco-retorno média, de acordo com o modelo geral $\mathbf{C}$

\begin{tabular}{|c|c|l|c|}
\hline Jarque-Bera (prob.) & 0,796835 & $\mathrm{R}^{2}$ ajustado & 0,459238 \\
\hline BPG (prob.) & 0,3036 & Estatística F & 8,643170 \\
\hline Breusch-Godfrey (prob.) & 0,7402 & Estatística F (prob.) & 0,000076 \\
\hline Variável & Coeficiente & Estatística t & Probabilidade \\
DRR Média P2 & 0,451858 & 3,254619 & 0,0027 \\
D16 & 0,041481 & 2,882251 & 0,0070 \\
D25 & $-0,029923$ & $-2,042835$ & 0,0494 \\
D30 & 0,043702 & 3,012787 & 0,0050 \\
Constante & 0,001274 & 0,187277 & 0,8526 \\
\hline
\end{tabular}

Elaborada pelo autor.

Os padrões apresentados nas tabelas 36 e 37 são basicamente os mesmos dos modelos parâmetros de comparação nas tabelas 24 e 25.

Tabela 38 - Resultados da regressão 17: decoupling no período 1, explicado pelo nível de globalização restrita, de acordo com o modelo geral $\mathrm{C}$

\begin{tabular}{|c|c|l|c|}
\hline Jarque-Bera (prob.) & 0,217486 & $\mathrm{R}^{2}$ ajustado & 0,246906 \\
\hline BPG (prob.) & 0,6253 & Estatística F & 6,027114 \\
\hline Breusch-Godfrey (prob.) & 0,3627 & Estatística F (prob.) & 0,001606 \\
\hline Variável & Coeficiente & Estatística t & Probabilidade \\
NGR P1 & 0,015333 & 0,609814 & 0,5452 \\
D36 & 0,045068 & 2,013349 & 0,0504 \\
D47 & 0,076218 & 3,474363 & 0,0012 \\
Constante & 0,024262 & 2,830736 & 0,0070 \\
\hline
\end{tabular}

Elaborada pelo autor.

Tabela 39 - Resultados da regressão 18: decoupling no período 2, explicado pelo nível de globalização restrita, de acordo com o modelo geral $\mathrm{C}$

\begin{tabular}{|c|c|c|c|}
\hline Jarque-Bera (prob.) & 0,331551 & $\mathrm{R}^{2}$ ajustado & 0,278433 \\
\hline BPG (prob.) & 0,6411 & Estatística F & 5,630465 \\
\hline Breusch-Godfrey (prob.) & 0,8845 & Estatística F (prob.) & 0,003135 \\
\hline Variável & Coeficiente & Estatística t & Probabilidade \\
\hline NGR P2 & 0,030884 & 0,669483 & 0,5078 \\
\hline D16 & 0,048755 & 2,802610 & 0,0084 \\
\hline D30 & 0,048633 & 2,869738 & 0,0071 \\
\hline Constante & 0,001407 & 0,046979 & 0,9628 \\
\hline
\end{tabular}

Elaborada pelo autor.

Não houve nenhuma mudança relevante quando se emprega, no modelo "C", o NGR como segue nas tabelas 38 e 39 . 
No geral, em comparação com os resultados do modelo “A”, o $\mathrm{R}^{2}$ ajustado é maior para todos os modelos "C" do período 1 . No período 2, somente o modelo que emprega a DRR média possui um $\mathrm{R}^{2}$ ajustado maior que o verificado no modelo " $\mathrm{A}$ ” (parâmetro de comparação).

Dessa forma, concluí-se que quando o índice mundial é o padrão para cálculo da magnitude do decoupling, existem mudanças significativas nos resultados dos modelos testados.

A diferença do próximo conjunto de modelos para o modelo "A" está no fato de que, para o cálculo da variável dependente, não é incluído o índice referente ao mercado acionário chinês. Como já comentado, as regressões D1 e E1 que utilizam a correlação média ou o NGR como variável dependente (vide tabelas 19 e 21) foram excluídas da análise.

Tabela 40 - Resultados da regressão 19: decoupling no período 2, explicado pela correlação média, de acordo com o modelo geral $\mathrm{D}$

\begin{tabular}{|c|c|c|c|}
\hline Jarque-Bera (prob.) & 0,790670 & $\mathrm{R}^{2}$ ajustado & 0,405487 \\
\hline BPG (prob.) & 0,2434 & Estatística F & 6,797421 \\
\hline Breusch-Godfrey (prob.) & 0,5040 & Estatística F (prob.) & 0,000510 \\
\hline Variável & Coeficiente & Estatística t & Probabilidade \\
\hline Correlação Média P2 & 0,062686 & 1,755401 & 0,0894 \\
\hline D16 & 0,052672 & 2,570295 & 0,0154 \\
\hline D24 & 0,052898 & 2,511103 & 0,0177 \\
\hline $\mathrm{AR}(2)$ & 0,379256 & 2,087957 & 0,0454 \\
\hline Constante & $-0,009942$ & $-0,399398$ & 0,6924 \\
\hline
\end{tabular}

Elaborada pelo autor.

Sobre a Tabela 40, a correlação média só é significativa a $10 \%$, perdendo, assim, poder de explicação da evolução da variável dependente. Contudo, esse resultado é importante para demonstrar que existem evidências de que a interação com a China é relevante para a geração de desempenhos diferenciados dos mercados dos BRIS no período 2, ou seja, nos anos mais recentes. Vale ressaltar que os coeficientes das variáveis D12, D25 e D30 deixam de ser significativos, sugerindo que seus respectivos eventos estavam associados com o desempenho do mercado chinês. Alternativamente, a variável D24 é identificada, associada com a data 30/09/2011. Não foram identificados eventos especiais com relação a essa data que possam ter um impacto nos mercados analisados.

Por fim, existem indícios de que o fenômeno do decoupling nos anos mais recentes possui um padrão em que o valor corrente do decoupling também depende significativamente dos valores dos últimos dois meses. Entretanto, esse padrão só se mostra evidente quando não se inclui o mercado chinês na construção da variável dependente. 
Tabela 41 - Resultados da regressão 20: decoupling no período 1, explicado pela distância risco-retorno média, de acordo com o modelo geral $D$

\begin{tabular}{|c|c|c|c|}
\hline Jarque-Bera (prob.) & 0,284958 & $\mathrm{R}^{2}$ ajustado & 0,367183 \\
\hline BPG (prob.) & 0,6163 & Estatística F & 7,672709 \\
\hline Breusch-Godfrey (prob.) & 0,9754 & Estatística F (prob.) & 0,000098 \\
\hline Variável & Coeficiente & Estatística t & Probabilidade \\
\hline DRR Média P1 & $-0,059927$ & $-0,245520$ & 0,8072 \\
\hline D32 & 0,081081 & 3,140156 & 0,0031 \\
\hline D36 & 0,079010 & 3,093039 & 0,0035 \\
\hline D40 & 0,089273 & 3,482369 & 0,0012 \\
\hline Constante & 0,042330 & 3,436809 & 0,0013 \\
\hline
\end{tabular}

Elaborada pelo autor.

Tabela 42 - Resultados da regressão 21: decoupling no período 2, explicado pela distância risco-retorno média, de acordo com o modelo geral $D$

\begin{tabular}{|c|c|l|c|}
\hline Jarque-Bera (prob.) & 0,816894 & $\mathrm{R}^{2}$ ajustado & 0,395232 \\
\hline BPG (prob.) & 0,3734 & Estatística F & 6,554972 \\
\hline Breusch-Godfrey (prob.) & 0,6716 & Estatística F (prob.) & 0,000648 \\
\hline Variável & \multicolumn{1}{|c|}{ Coeficiente } & Estatística t & Probabilidade \\
DRR Média P2 & 0,357792 & 1,442751 & 0,1595 \\
D16 & 0,042058 & 2,062678 & 0,0479 \\
D24 & 0,053652 & 2,642939 & 0,0129 \\
AR(2) & 0,460009 & 2,760609 & 0,0097 \\
Constante & 0,016627 & 1,272738 & 0,2129 \\
\hline
\end{tabular}

Elaborada pelo autor.

Na Tabela 41, o poder explicativo da constante, ainda significativa, sugere que a diferença de desempenhos dos mercados de Brasil, Rússia, Índia e África do Sul em relação ao mercado dos EUA no período 1 existiu e foi relevante. Com isso, a hipótese de que o decoupling é um fenômeno que compreendeu somente o mercado chinês é rejeitada, pelo menos no período 1.

Outro ponto importante referente a Tabela 41 é o fato de o coeficiente da variável D47 deixar de ser significativo. Assim, é possível supor que o evento relativo a essa dummy está unicamente associado ao desempenho do mercado chinês. Por outro lado, novas dummies são identificadas: D32 e D40, referentes às datas 30/09/2005 e 31/05/2006, respectivamente. Não foram identificados eventos especiais com relação a essas datas que possam ter um impacto nos mercados analisados.

Na Tabela 42, verifica-se que a DRR média deixou de ser significativa no período 2. 
Tabela 43 - Resultados da regressão 22: decoupling no período 2, explicado pelo nível de globalização restrita, de acordo com o modelo geral D

\begin{tabular}{|c|c|c|c|}
\hline Jarque-Bera (prob.) & 0,842039 & $\mathrm{R}^{2}$ ajustado & 0,373615 \\
\hline BPG (prob.) & 0,5604 & Estatística F & 6,069932 \\
\hline Breusch-Godfrey (prob.) & 0,7821 & Estatística F (prob.) & 0,001058 \\
\hline Variável & Coeficiente & Estatística t & Probabilidade \\
\hline NGR P2 & 0,076222 & 0,960514 & 0,3445 \\
\hline D16 & 0,050497 & 2,482751 & 0,0189 \\
\hline D24 & 0,052968 & 2,551180 & 0,0161 \\
\hline $\mathrm{AR}(2)$ & 0,482100 & 2,898990 & 0,0069 \\
\hline Constante & $-0,016354$ & $-0,317390$ & 0,7531 \\
\hline
\end{tabular}

Elaborada pelo autor.

Ao se analisar a Tabela 43, observa-se que a variável NGR continua sem poder de explicação para o decoupling em questão.

Os resultados dos modelos que compreendem as tabelas 40 a 43 servem como indícios de que a integração financeira entre os BRICS não parece ser um fator determinante para explicar desempenhos diferenciados das bolsas de Brasil, Rússia, Índia e África do Sul em relação ao desempenho do mercado dos EUA, com a exceção do modelo que emprega correlação média no período 2 que deve ser levada em consideração (vide Tabela 40). Portanto, uma interpretação plausível é a de que a integração entre os mercados acionários dos BRICS parece ser um fator determinante para o desempenho do mercado chinês, principalmente no período 1. Essa interpretação, de certa forma, serve como justificativa para a estratégia da China de explorar parcerias com mercados menos tradicionais.

Entretanto, o fenômeno do decoupling no período 1 não deixou de existir após a retirada da China da variável dependente.

Por fim, com exceção do modelo da Tabela 40, em comparação com as regressões relativas ao modelo geral "A", o R ${ }^{2}$ ajustado foi maior nos modelos que não incluíram a China na variável dependente. Dado que os coeficientes das proxies para integração financeira, em geral, não foram significativos, o mérito se deve às novas dummies e ao comportamento autorregressivo identificado no período 2 .

No último conjunto de modelos, o índice referente ao mercado chinês é retirado do cálculo da variável dependente e da independente. 
Tabela 44 - Resultados da regressão 23: decoupling no período 2, explicado pela correlação média, de acordo com o modelo geral $\mathbf{E}$

\begin{tabular}{|c|c|l|c|}
\hline Jarque-Bera (prob.) & 0,840067 & $\mathrm{R}^{2}$ ajustado & 0,356565 \\
\hline BPG (prob.) & 0,1821 & Estatística F & 5,710350 \\
\hline Breusch-Godfrey (prob.) & 0,9550 & Estatística F (prob.) & 0,001536 \\
\hline Variável & \multicolumn{1}{|c|}{ Coeficiente } & Estatística t & Probabilidade \\
Correlação Média P2 & 0,011375 & 0,316541 & 0,7538 \\
D16 & 0,047491 & 2,336690 & 0,0263 \\
D24 & 0,055465 & 2,656479 & 0,0125 \\
AR(2) & 0,495840 & 2,884428 & 0,0072 \\
Constante & 0,023925 & 0,838074 & 0,4086 \\
\hline
\end{tabular}

Elaborada pelo autor.

Na Tabela 44, observa-se que não há influência da correlação média no período 2. Assim, é possível interpretar que a relação entre as variáveis proposta neste trabalho só faz sentido quando a China é incluída, pelo menos, na variável independente (vide Tabela 40). Desse resultado é perceptível a importância da China na interação entre os mercados dos BRICS, corroborando a hipótese de que o mercado chinês é a principal fonte de dinamismo dentro do grupo. De resto, o modelo da tabela 44 segue os mesmos padrões identificados no modelo em que o mercado chinês não era incluído na variável dependente.

Tabela 45 - Resultados da regressão 24: decoupling no período 1, explicado pela distância risco-retorno média, de acordo com o modelo geral $\mathrm{E}$

\begin{tabular}{|c|c|l|c|}
\hline Jarque-Bera (prob.) & 0,292579 & $\mathrm{R}^{2}$ ajustado & 0,371283 \\
\hline BPG (prob.) & 0,6342 & Estatística F & 7,791227 \\
\hline Breusch-Godfrey (prob.) & 0,9528 & Estatística F (prob.) & 0,000086 \\
\hline Variável & Coeficiente & Estatística t & Probabilidade \\
DRR Média P1 & $-0,075831$ & $-0,578434$ & 0,5661 \\
D32 & 0,080003 & 3,113855 & 0,0033 \\
D36 & 0,078595 & 3,085381 & 0,0036 \\
D40 & 0,088230 & 3,464036 & 0,0012 \\
Constante & 0,043583 & 5,390615 & 0,0000 \\
\hline
\end{tabular}

Elaborada pelo autor.

Tabela 46 - Resultados da regressão 25: decoupling no período 2, explicado pela distância risco-retorno média, de acordo com o modelo geral $\mathrm{E}$

\begin{tabular}{|c|c|c|c|}
\hline Jarque-Bera (prob.) & 0,812204 & $\mathrm{R}^{2}$ ajustado & 0,359089 \\
\hline BPG (prob.) & 0,5258 & Estatística F & 5,762374 \\
\hline Breusch-Godfrey (prob.) & 0,9084 & Estatística F (prob.) & 0,001454 \\
\hline Variável & Coeficiente & Estatística t & Probabilidade \\
\hline DRR Média P2 & 0,094966 & 0,474479 & 0,6386 \\
\hline D16 & 0,045158 & 2,154864 & 0,0393 \\
\hline D24 & 0,055806 & 2,704208 & 0,0112 \\
\hline $\operatorname{AR}(2)$ & 0,494738 & 2,004688 & 0,0541 \\
\hline Constante & 0,027282 & 2,992334 & 0,0055 \\
\hline
\end{tabular}

Elaborada pelo autor.

Diferente do que foi já foi analisado, nos resultados da Tabela 46, a constante foi significativa a $1 \%$. Com isso, são apresentados indícios de que pode ter existido uma diferença significativa de desempenho entre os mercados de Brasil, Rússia, Índia e África do Sul e o 
mercado dos EUA nos períodos 1 e 2. Adicionalmente, pode-se supor que, durante todos os períodos analisados, existiram oportunidades claras de diversificação internacional para portfólios que incluíssem empresas dos BRIS e dos EUA ao mesmo tempo. Também vale ressaltar que, em comparação com os resultados da Tabela 42, o decoupling mínimo só ficou visível no período 2, ou seja, a constante só foi significativa quando a China foi retirada do cálculo da variável independente. Essa interação aparece quando se observa que, da Tabela 42 para a 46, a DRR média perdeu poder de explicação enquanto a constante ganhou. A partir disso, pode-se conjecturar que o decoupling entre os mercados de Brasil, Rússia, Índia e África do Sul e o mercado dos EUA tem como fator determinante a interação dos mercados dos BRIS com o mercado chinês no período 2. Assim, as recentes oportunidades de diversificação internacional citadas anteriormente podem estar ligadas à evolução do mercado chinês.

Tabela 47 - Resultados da regressão 26: decoupling no período 2, explicado pelo nível de globalização restrita, de acordo com o modelo geral $\mathbf{E}$

\begin{tabular}{|c|c|l|c|}
\hline Jarque-Bera (prob.) & 0,907480 & $\mathrm{R}^{2}$ ajustado & 0,354460 \\
\hline BPG (prob.) & 0,7756 & Estatística F & 5,667265 \\
\hline Breusch-Godfrey (prob.) & 0,9599 & Estatística F (prob.) & 0,001607 \\
\hline Variável & Coeficiente & Estatística t & Probabilidade \\
NGR Média P2 & $-0,008750$ & $-0,093817$ & 0,9259 \\
D16 & 0,047448 & 2,326366 & 0,0269 \\
D24 & 0,056171 & 2,698889 & 0,0113 \\
AR(2) & 0,498840 & 3,029862 & 0,0050 \\
Constante & 0,039425 & 0,542791 & 0,5913 \\
\hline
\end{tabular}
Elaborada pelo autor.

Os resultados da tabela 47 só confirmam que, quando a variável NGR é empregada, a integração financeira não é interpretada como significativa em nenhum dos períodos e em nenhum dos modelos possíveis aqui analisados.

Em geral, os modelos elaborados a partir desse último conjunto de índices, quando comparados com os modelos do conjunto base "A", apresentam indícios de que o mercado chinês é fundamental para que a integração entre os mercados dos BRICS produza sinergias que façam com que esses mercados apresentem desempenhos diferenciados em relação ao desempenho do mercado estadunidense.

Abaixo seguem os quadros com os principais resultados encontrados. Os resultados diferentes dos encontrados com os modelos elaborados a partir do conjunto base de índices "A" estão destacados nos quadros. 
Quadro 9 - Resumo dos resultados das regressões referentes ao modelo geral A

\begin{tabular}{|l|c|c|}
\hline Variável & Sinal & É significativa? \\
\hline Constante - período 1 & + & Sim \\
\hline Correlação média - período 1 & + & Sim \\
\hline Distância risco-retorno média - período 1 & - & Não \\
\hline Nível de globalização restrita - período 1 & + & Não \\
\hline Constante nos modelos de correlação média e de NGR- período 2 & - & Não \\
\hline Constante no modelo de DRR média - período 2 & + & Não \\
\hline Correlação média - período 2 & + & Sim \\
\hline Distância risco-retorno média - período 2 & + & Sim \\
\hline Nível de globalização restrita - período 2 & + & Não \\
\hline
\end{tabular}

Elaborado pelo autor.

Quadro 10 - Resumo dos resultados das regressões referentes ao modelo geral B

\begin{tabular}{|l|c|c|}
\hline Variável & Sinal & É significativa? \\
\hline Constante - período 1 & + & Sim \\
\hline Correlação média - período 1 & + & Sim \\
\hline Distância risco-retorno média - período 1 & - & Sim \\
\hline Nível de globalização restrita - período 1 & + & Não \\
\hline Constante nos modelos de correlação média e de NGR- período 2 & - & Não \\
\hline Constante no modelo de DRR média - período 2 & + & Não \\
\hline Correlação média - período 2 & + & Sim \\
\hline Distância risco-retorno média - período 2 & + & Sim \\
\hline Nível de globalização restrita - período 2 & + & Não \\
\hline
\end{tabular}

Elaborado pelo autor.

\section{Quadro 11 - Resumo dos resultados das regressões referentes ao modelo geral C}

\begin{tabular}{|l|c|c|}
\hline Variável & Sinal & É significativa? \\
\hline Constante - período 1 & + & Sim \\
\hline Correlação média - período 1 & + & Sim \\
\hline Distância risco-retorno média - período 1 & - & Não \\
\hline Nível de globalização restrita - período 1 & + & Não \\
\hline Constante - período 2 & + & Não \\
\hline Correlação média - período 2 & - & Não \\
\hline Distância risco-retorno média - período 2 & + & Sim \\
\hline Nível de globalização restrita - período 2 & + & Não \\
\hline
\end{tabular}

Elaborado pelo autor.

Quadro 12 - Resumo dos resultados das regressões referentes ao modelo geral D

\begin{tabular}{|l|c|c|}
\hline Variável & Sinal & É significativa? \\
\hline Constante - período 1 & + & Sim \\
\hline Distância risco-retorno média - período 1 & - & Não \\
\hline Constante nos modelos de correlação média e de NGR- período 2 & - & Não \\
\hline Constante no modelo de DRR média - período 2 & + & Não \\
\hline Correlação média - período 2 & + & Sim \\
\hline Distância risco-retorno média - período 2 & + & Não \\
\hline Nível de globalização restrita - período 2 & + & Não \\
\hline
\end{tabular}

Elaborado pelo autor. 
Quadro 13 - Resumo dos resultados das regressões referentes ao modelo geral E

\begin{tabular}{|l|c|c|}
\hline Variável & Sinal & É significativa? \\
\hline Constante - período 1 & + & Sim \\
\hline Distância risco-retorno média - período 1 & - & Não \\
\hline Constante nos modelos de correlação média e de NGR- período 2 & + & Não \\
\hline Constante no modelo de DRR média - período 2 & + & Sim \\
\hline Correlação média - período 2 & + & Não \\
\hline Distância risco-retorno média - período 2 & + & Não \\
\hline Nível de globalização restrita - período 2 & - & Não \\
\hline
\end{tabular}

Elaborado pelo autor.

Com o que foi analisado nesse capítulo, percebe-se que os resultados podem variar segundo:

- a variável independente escolhida;

- o conjunto de índices escolhido; e

- o período analisado.

De uma forma geral, os modelos que empregaram a correlação média como variável independente obtiveram os maiores $\mathrm{R}^{2}$ ajustados, seguidos dos modelos que empregaram a DRR média.

Mesmo com a variabilidade dos resultados, é importante documentar que em quatro das modelos gerais foi estimada pelo menos uma regressão em que uma proxy para integração entre os mercados acionários dos BRICS foi significativa para explicar a evolução do decoupling. Além disso, em todas as combinações foram identificados indícios de decoupling significativo em pelo menos um dos períodos que foram abordados.

Outro ponto relevante é a diferença dos resultados dos modelos de um período para outro, ou seja, os resultados variaram significativamente antes e depois da crise financeira de 2008, sugerindo uma mudança de padrões nos mercados analisados após a crise. Adicionalmente, é importante observar que, em geral, os $\mathrm{R}^{2}$ ajustados foram maiores para as regressões do período 2 , ou seja, a relação entre as variáveis proposta parece fazer maior sentido após a crise. Assim, pode-se concluir que existem indícios de que a importância da integração entre os mercados dos BRICS tornou-se maior para o desempenho desses mercados nos últimos três anos.

Também é importante a detecção de evidências de que os desempenhos dos mercados dos BRICS seriam significativamente diferentes do desempenho mundial como um todo. 
Por fim, ao se verificar mudanças relevantes quando se retirou a China dos modelos, também está documentada a importância do mercado chinês para os desempenhos dos outros mercados dos BRICS.

A relação entre os resultados observados e o que já foi observado em trabalhos anteriores segue no Quadro 14.

Quadro 14 - Correspondência entre os resultados encontrados e os resultados de trabalhos anteriores

\begin{tabular}{|l|l|}
\hline Resultado observado & Trabalhos relacionados que possuem
\end{tabular}

A presença da China produz mudanças relevantes no modelo resultados parecidos analisado, ou seja, a China responde por grande parte do dinamismo do grupo

Diagnóstico de integração financeira crescente no mesmo período em que existe uma intensificação do comércio entre os países analisados.

Santos (2010)

Integração financeira medida depende dos países incluídos na Chittedi (2009), Johnson e Soenen (2003), Frankel e Rose (1998), Hamao et al (1990), Phylaktis e Ravazzolo (2002) e Santos (2010) análise e do período abordado.

Padrão de desempenho do índice mundial muito parecido com o padrão do mercado dos EUA, demonstrando a influência desse no mundo

Possível decoupling nos mercados acionários, incluindo os BRICS Bekaert e Harvey (1995)

Evidências de que a interação entre os mercados do grupo BRICS Eun e Shim (1998) e Masih e Masih (2001)

tem afetado cada vez mais a evolução desses mercados, ou seja, um fator grupo tem ganhado poder de explicação de desempenhos em relação aos fatores internacionais gerais 


\section{CONSIDERAÇÕES FINAIS}

Com base no aumento do comércio entre os países emergentes na última década, que tem gerado uma maior integração financeira entre os mesmos, esta pesquisa buscou avaliar a relação entre a integração entre os mercados acionários dos BRICS e o desempenho desses mercados, tendo como parâmetro o desempenho do mercado dos Estados Unidos. Mais precisamente, foi estudado se essa integração seria determinante para a geração de um diferencial de desempenho significativo, sistemático e recorrente para os mercados acionários dos BRICS em relação ao desempenho do mercado dos EUA. Esse tipo de diferencial de desempenho foi interpretado como um decoupling entre os mercados dos BRICS e do mercado norte-americano.

A partir de índices que representam a evolução dos mercados em questão, foram gerados modelos cujas variáveis independentes serviram de proxy para a integração entre as bolsas dos BRICS e a variável dependente representou a evolução do decoupling. Os modelos foram gerados antes e depois da crise financeira de 2008, abrangendo o período total de 2003 a outubro de 2012.

Dentre os resultados encontrados, destaca-se a existência de evidências que suportam a tese de existência de decoupling entre os mercados dos BRICS e o mercado dos EUA. Assim, a interpretação é a de que, mesmo com todo o processo de globalização das cadeias de produção, das redes de comunicação, etc; ainda podem existir diferenças substanciais entre os desempenhos das bolsas dos BRICS e das bolsas dos mercados dos países desenvolvidos nos anos mais recentes. Ademais, com esse diferencial significativo, pode-se afirmar que existiram claras oportunidades de diversificação internacional de portfólios de investimento na última década.

Também foram encontradas evidências de que a integração entre os mercados acionários dos BRICS seria um fator determinante para explicar a evolução do decoupling estudado. Essas evidências, de certa forma, contribuem para a validação das premissas do modelo teórico em que a integração entre os mercados acionários nada mais é que o reflexo de um amplo processo de integração financeira entre os BRICS decorrente da intensificação do comércio entre esses países na última década e, assim, com esse processo, diminuir-se-ia a dependência desses países em relação aos Estados Unidos e um dos reflexos seria a redução da sincronia entre os mercados dos BRICS e o mercado estadunidense. Além disso, esse resultado 
fortalece a tese de que os fatores referentes a grupos de países estão, cada vez mais, explicando melhor os desempenhos desses países (e de seus mercados acionários), fazendo frente aos fatores internacionais tradicionais, típicos do fenômeno da globalização, que tendem a equalizar os desempenhos de todos os países. Por fim, essa possível influência significativa da integração financeira indica que o fator país ainda é importante para explicar o desempenho das bolsas e que a interação entre esses fatores, como acontece na integração financeira, pode produzir resultados significativos para esse desempenho.

Outro ponto importante é a diferença relevante nos resultados quando se retira a China dos modelos gerados. Essa diferença identificada, de maneira geral, documenta e ajuda a quantificar o impacto e a importância do mercado acionário chinês para os outros mercados dos BRICS, defendendo a hipótese de que a China, com todas as suas particularidades, é um dos principais fatores para explicar o dinamismo dos mercados do grupo.

Nos modelos que não incluíram a China e que abordaram o período após a crise, foi identificado um comportamento autorregressivo da variável dependente que utiliza os valores dos últimos dois meses como variáveis independentes. Assim, pode-se afirmar que existem indícios de que o decoupling medido depende de seus valores anteriores quando não se inclui a China.

Evidentemente, a validade dos resultados apresentados e de suas respectivas interpretações está condicionada à qualidade das variáveis independentes utilizadas. A principal limitação da pesquisa refere-se ao fato de a evolução dos índices das bolsas utilizados, base das variáveis empregadas, não representar todos os fluxos de capital referentes às transações que envolvem as bolsas analisadas.

Para pesquisas futuras, sugere-se:

1. a investigação de possíveis variáveis referentes ao espectro da economia real que sirvam como fatores determinantes para explicar a integração financeira, que foi medida nesta pesquisa, para que se possa elaborar um modelo mais amplo que explique o decoupling entre mercados por meio de dados da economia real;

2. investigar a existência de um possível decoupling entre a China e os outros países emergentes; 
3. medir a qualidade das atuais proxies para integração financeira e elaborar outras que melhor representem o comportamento médio do fenômeno;

4. investigar os fenômenos decoupling e integração financeira sob o ponto de vista setorial e não por países;

5. a incorporação direta de medidas de risco na construção de variáveis que meçam o decoupling. 


\section{REFERÊNCIAS}

AGGARWAL, R.; KYAW, N. A. Equity market integration in the NAFTA region: Evidence from unit root and cointegration tests. International Review of Financial Analysis, v. 14, p. 393-406, 2005.

AHLGREN, N.; ANTELL, J. Stock market linkages and financial contagion: A cobreaking analysis. The Quarterly Review of Economics and Finance, v. 50, p. 157-166, 2010.

AKIN, C.; KOSE, M. A. Changing nature of North-South linkages: Stylized facts and explanations. Journal of Asian Economics, v. 19, n. 1, p. 1-28, 2008.

ALMEIDA, L. M. A.; RIGOLIN, T. B. Geografia. 2. ed. 6. reimpr. São Paulo: Ática, 2006.

ALOUI, R.; AISSA, M. S. B.; NGUYEN, D. K. Global financial crisis, extreme interdependences, and contagion effects: the role of economic structure? Journal of Banking and Finance, v. 35, p. $130-141,2011$.

ANDRADE, D. C. Fatores condicionantes do crescimento econômico de longo prazo na China: aspectos teóricos e investigação empírica. Dissertação (Mestrado)-IE-UFU, Uberlândia, MG, fev. 2006.

ANDREZZO, A. F.; LIMA, I. S. Mercado financeiro: aspectos conceiuais e históricos. 3. Ed. São Paulo: Atlas, 2007.

ARBORA, V.; VAMVAKIDIS, A. The implications of South African Economic Growth For The Rest Of Africa. South African Journal of Economics, v. 73, n. 2, p. 229-242, 2005.

ARMIJO, L. E. The BRICS countries (Brazi, Russia, India and China) as analytical category: mirage or insight? Asian Perspective, v. 31, n. 4, p. 7-42, 2007.

ASSAF NETO, A. Mercado financeiro.8. Ed. São Paulo: Atlas, 2008.

BAELE, L.; FERRANDO, A.; HÖRDAHL, P.; KRYLOVA, E.; MONNET, C. Measuring financial integration in the euro area. ECB Occasional Paper Series 14, Frankfurt, 2004.

BAFFES, J. Explaining stationary variables with non-stationary regressors. Applied Economic Letters, v. 4, n. 1, p. 69-75,1997.

BANCO MUNDIAL. Disponível em: http://www.worldbank.org/ Acessado em: 12 set. 2012.

BAO, D. Usefulness of financial information in evaluation of BRIC firms. Advances in Accounting, incorporating Advances in International Accounting, v. 25, p. 200-207, 2009.

BASKARAN, A.; MUCHIE, M. Foreign Direct Investment and Internationalization of R\&D: The Case of BRICS Economies Development, Innovation and International Political Economy Research (DIIPER). Aalborg University, Denmark. DIIPER Research Series, Working Paper No. 7, 2008. Disponível em: http://www.diiper.ihis.dk. 
BAUMANN, R. Some recent features of Brazil-China economic relations. Cepal, LC/BRS/R. 205, 2009, Disponível em: www.cepal.org/brasil.

BECKER, K. G.; FINNERTY, J. E.; TUCKER, A.L. The intraday interdependence structure between US and Japanese equity markets. Journal of Financial Research, v. 25, p. 27-37, 1992.

BEINE, M.; COSMA, A.; VERMEULEN, R. The dark side of global integration: Increasing tail dependence. Journal of Banking and Finance, v. 34, n. 1, p. 184-192, 2010.

BEKAERT, G.; HARVEY, C. R. Time-Varying world market integration. Journal of Finance, v. 50, p. 403-444, 1995.

BEKAERT, G.; HARVEY, C. R. Foreign speculation and emerging equity markets. Journal of Finance, v. 55, p. 565-613, 2000.

BEKAERT, HARVEY, C. AND LUMSDAINE, R. Dating the integration of world equity markets, Journal of Financial Economics, v. 65, n. 2, p. 203-247, 2002.

BEKAERT, G.; HARVEY, C. R.; LUNDBLAD, C. T. Equity market liberalisation in emerging markets. Journal of Financial Research, v. 3, p. 275-299, 2003.

BEKAERT, G.; HARVEY, C. R.; LUNDBLAD C. Does Financial Liberalization Spur Growth? Journal of Financial Economics, v. 77, n. 1, p. 3-55, 2004.

BELDERBOS, R. R\&D activities in East Asia by Japanese, European, and US multinationals. JCER discussion paper, n. 100, 2006.

BESSLER, D. A.; YANG, J. The structure of interdependence in international stock markets. Journal of International Money and Finance, v. 22, p. 261-287, 2003.

BIGGEMANN, S.; FAM, K. Business marketing in BRIC countries. Industrial Marketing Management, v. 40, p. 5-7, 2011.

BM\&FBOVESPA. Bolsas dos BRICS terão listagem cruzada de derivativos dos índices de ações mais representativos de seus mercados, 13 de março de 2012. Disponível em: http://www.bmfbovespa.com.br/pt-br/noticias/2012/Bolsas-dos-BRICS-terao-listagemcruzada-de-derivativos-dos-indices-de-acoes-mais-representativos-de-seus-mercados-201203-13.aspx?tipoNoticia=1\&idioma=pt-br Acessado em: 20 de setembro de 2012.

BOLlERSLEV, T.; CHOU, R. Y.; KRONER, K. F. ARCH Modeling in Finance: A Review of the Theory and Empirical Evidence. Journal of Econometrics, v. 52, p. 5-60, 1992.

BOSWORTH, B.; COLLINS, S. M.; VIRMANI, A. Sources of growth in the Indian economy. NBER Working Paper, n. 12901, 2007.

BRACKER, K.; DOCKING, D. S.; KOCH, P. D. Economic determinants of evolution in international stock market integration. Journal of Empirical Finance, v. 27, n. 1, p. 1-27, 1999. 
BROOKS, R. D.; DAVIDSON, S.; FAFF, R. W. An examination of the effects of major political change on stock market volatility: the South African experience. Journal of International Financial Markets, Institutions and Money, v. 7, p. 255-275, 1997.

BRUNI, A.L.; FUENTES, J.; FAMÁ, R. A. Moderna Teoria de Portfólios e a Contribuição dos Mercados Latinos na Otimização da Relação Risco Versus Retorno de Carteiras Internacionais: Evidências Empíricas Recentes (1996-1997) III Semead FEA/USP. São Paulo: USP, 1998.

BÜTTNER, D.; HAYO, B. Determinants of European stock market integration. Economic Systems, v. 35, p. 574-585, 2011.

CALDERON, C.; CHONG, A.; STEIN, E. Trade intensity and business cycle synchronization: are developing countries any different? Journal of International Economics, v. 71, p. 2-21, 2007.

CAPIELLO, L.; ENGLE, R. H.; SHEPPARD, K. Asymmetric dynamics in the correlations of global equity and bond returns. Journal of Financial Econometrics, v. 4, p. 537-572, 2006.

CHENG et al. A future global economy to be built by BRICs. Global Finance Journal, v. 18, p. 143-156, 2007.

CHILD, J.; RODRIGUES, S. B. The Internationalization of Chinese Firms: A Case for Theoretical Extension? Management and organization review, v. 1, n. 3, p. $381-410$, 2005.

CHINN, M.; FRANKEL, J. Why the Euro will Rival the Dollar. International Finance , v. 11, n. 1, p. 49-73, 2008.

CHITTEDI, K. R. Global Stock Markets Development and Integration: with Special Reference to BRIC Countries. University Library of Munich, Germany. MPRA Paper n. $18602,2009$.

CIA - Central Intelligence Agency. Disponível em: https://www.cia.gov. Acessado em: 5 set. 2012.

COLLINS, D.; BIEKPE, N. Contagion and interdependence in African stock markets. The South African Journal of Economics, v. 71, n. 1, p. 181-194, 2003.

CONNOLY, R. A.; WANG, F. A. International equity market comovements: Economic fundamentals or contagion? Pacific-Basin Finance Journal, v. 11, p. 23-23, 2003.

CORSETTI, G.; PERICOLI, M.; SBRACIA, M. Some contagion, some interdependence: Morepitfalls in tests of financial contagion. Journal of International Money and Finance, v. 24, p. 1177-1199, 2005.

DA SILVEIRA, A. M. Governança corporativa e estrutura de propriedade: determinantes e relação com o desempenho das empresas no Brasil. Tese para obtenção do título de Doutor em Administração pela Universidade de São Paulo (USP), 2004. 
DE PAULA, L. F. R.; FERRARI FILHO, F. Liberalização financeira e performance econômica: a experiência recente dos BRIC. In: $1^{\circ}$ Encontro Nacional de Economia Política, 2006.

DOOLEY, M.; HUTCHINSON, M. Transmission of the U. S. subprime crisis to emerging markets: Evidence on the decoupling-recoupling hypothesis. Journal of International Money and Finance, v. 28, p. 1331-1349, 2009.

DORNBUSCH, R.; PARK, Y. C.; CLAESSENS, S. Contagion: How it spreads and how it can be stopped? World Bank Research Observer, v. 15, n. 2, p. 97-177, 2000.

DUNGEY, M.; MARTIN, V. L. Unravelling financial market linkages during crises. Journal of Applied Econometrics, v. 22, p. 89-119, 2007.

EDWARDS, L. Globalisation and The Skills Bias of Occupational Employment in South Africa. The South African Journal of Economics, v. 69, n. 1, p. 40-71, 2001.

EDWARDS, L.; LAWRENCE, R. Z. South African trade policy matters: trade performance and trade policy. NBER Working Paper Series, n. 12760. Nov. 2006.

ENGLE, R.; GRANGER, C. W. J. Co-integration and error correction representation, estimation and testing. Econometrica, v. 66, p. 251-276, 1987.

ENGLE R.; ITO, T.; LIN, W. L. Metro showers or heat waves? Heteroskedastic intra-daily volatility in the foreign exchange markets. Econometrica, Econometric Society, v. 58, n. 3, p. 525-42, 1990.

ENGLE, R., HAKKIO, R. Statistical models of financial volatility. Financial Analysts Journal, v. 49, p. 1-20, 1993.

ENISAN, A. A.; OLUFISAYO, A. O. Stock market development and economic growth: Evidence from seven sub-Sahara African countries. Journal of Economics and Business, v. 61, p. 162-171, 2009.

ESTRIN, S.; PREVEZER, M. A survey on institutions and new firm entry: How and why do entry rates differ in emerging markets? Economic Systems, v. 34, p. 289-308, 2010.

EUN, C. S.; LEE, J. Mean-variance convergence around the world. Journal of Banking and Finance, v. 34, p. 856-870, 2010.

EUN, C. S.; SHIM, S. International Transmission of Stock Markets Movements. Journal of Financial and Quantitative Analysis, v. 24, n. 2, p. 241-256, 1989.

FÁVERO, L. P. et al. Análise de dados: modelagem multivariada para tomada de decisões. Rio de Janeiro: Elsevier, 2009.

FEDDERKE, J. W. The Structure of Growth in the South African Economy: Factor Accumulation and Total Factor Productivity Growth 1970-97. South Africa Journal of Economics, v. 70, n. 4, p. 612-646, 2002. 
FELICES, G.; WIELADEK, T. Are emerging market indicators of vulnerability to financial crises decoupling from global factors? Journal of Banking \& Finance, v. 36, p. 321-331, 2012.

FESTEL, G. Investing in Indian R\&D: new money pouring into research \& development in India makes the country an attractive place for innovation, 2008. Disponível em:

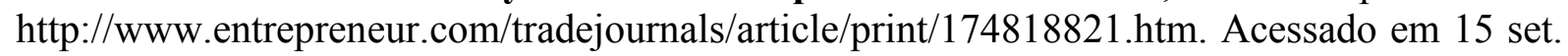
2012.

FIDRMUC, J.; KORHONEN, I. The impact of the global financial crisis on business cycles in Asian emerging economies. Journal of Asian Economics, v. 21, p. 293-303, 2010.

FLOOD, R.; ROSE, A. Inflation targeting and business cycle synchronization. Journal of International Money and Finance, v. 29, n. 4, p. 704-727, 2010.

FMI - $\quad$ Fundo Monetário Internacional. Disponível em: http://www.imf.org/external/index.htm. Acessado em: 3 mai. 2013.

FORBES, K. J.; RIGOBON, R. No contagion, only interdependence: measuring stock market comovements. Journal of Finance, v. 57, n. 5, p. 2223-2261, 2002.

FORTUNA, E. Mercado financeiro: produtos e serviços. 18 ed. Rio de Janeiro: Qualitymark, 2010.

FRANKEL, J. On the rand: determinants of the South African exchange rate. NBER Working Paper Series, n. 13050, 2007.

FRANKEL, J.; ROSE, A. The endogeneity of the optimum currency area criteria, The Economic Journal, v. 108, p. 1009-1025, 1998.

FRATZSCHER, M. Financial market integration in Europe: on the effects of EMU on stock markets. International Journal of Finance and Economics, v. 7, p. 165-193, 2002.

GAPMINDER. Disponível em: http://www.gapminder.org/world. Acessado em: 3 mai. 2013.

GLOBAL RATES. Disponível em: http://pt.global-rates.com/taxa-de-juros/bancoscentrais/bancos-centrais.aspx. Acessado em: 03 mai. 2013.

GOETZMAnN, W. N.; LI, L.; ROUWENHORST, K. G. Long-Term Global Market Correlations. Yale ICF Working Paper n. 00-60 37, 2002.

GOOIJER, J. G.; SIVARAJASINGHAM, S. Parametric and nonparametric Granger causality testing: Linkages between international stock markets. Physica A, v. 387, p. 2547-2560, 2008.

GRANGER, C. W. J.; NEWBOLD, P. Spurious regressions in econometrics, Journal of Econometrics, v. 2, p. 111-120, 1974.

GREMAUD, A. P.; VASCONCELlOS, M. A. S.; TONETO JÚNIOR, R. Economia brasileira contemporânea. 7. ed., 4. reimpr. São Paulo: Atlas, 2009.

GUJARATI, D. Econometria básica. 1. ed. Rio de Janeiro: Elsevier, 2006. 
HAMAO, Y. R.; MASULIS, R. W.; NG, V. K. Correlation in price changes and volatility across international stock markets. The Review of Financial Studies, v. 3, p. 281-307, 1990.

HAMMOUDEH, S.; SARI, R.; UZUNKAYA, M.; LIU, T. The dynamics of BRICS's country risk ratings and domestic stock markets, U.S. stock market and oil price. Mathematics and Computers in Simulation, 2012.

HARDOUVELIS, G. Evidence on stock market speculative bubbles: Japan, the United States, and Great Britain. Federal Reserve Bank of New York Quarterly Review, v. 13, n. 2., p. 4$16,1988$.

HIRAKAWA, H.; AUNG, T. T. Globalization and the Emerging Economies: East Asia's Structural Shift from the NIEs to Potentially Bigger Market Economies (PoBMEs). Evolutionary and Institutional Economics Review, v. 8, n. 1, p. 39-63, 2011.

HOLTBRÜGGE, D.; KREPPEL, H. Determinants of outward foreign direct investment from BRIC countries: an explorative study. International Journal of Emerging Markets, v. 7, n. 1, p. 4-30, 2012.

IBBOTSON, R. G.; CARR, R. C.; ROBINSON, A. W. International equity and bond returns. Financial Analysts Journal, p. 61-83, ago. 1982.

IMBS, J. Trade, Finance, Specialization, and Synchronization. Review of Economics and Statistics, v. 86, p. 723-34, 2004.

IMBS, J. The Real Effects of Financial Integration. Journal of International Economics, v. 68 , n. 2, p. 296-324, 2006.

JAYARAM, S.; PATNAIK, I.; SHAH, A. Examining the Decoupling Hypothesis for India. National Institute of Public Finance and Policy New Delhi. Working Paper, n. 2009-61, 2009. Disponível em: http://www.nipfp.org.in. Acessado em: 12 set. 2012.

JOHNSON, R.; SOENEN, L. Economic integration and stock market comovement in the Americas. Journal of Multinational Financial Management, v. 13, p. 85-100, 2003.

KAHN, M. The fall of the Wall, the rise of the BRICs and the new Scramble for Africa. Foresight, v. 13, n. 3, 2011.

KASA, K. (1992), "Common stochastic trends in international stock markets", Journal of Monetary Economics,v. 29, p. 95-124, 1992.

KAWAI, M. East Asian economic regionalism: Progress and challenges. Journal of Asian Economics, v. 16, p. 29-55, 2005.

KEARNEY, C. The determination and international transmission of stock market volatility. Global Finance Journal, v. 11, p. 31-52, 2000.

KEARNEY, C.; LUCEY, B. M. International equity market integration: Theory, evidence and implications. International Review of Financial Analysis, v. 13, p. 571-583, 2004. 
KENOURGIOS, D.; SAMITAS, A.; PALTALIDIS, N. Financial crises and stock market contagion in a multivariate time-varying asymmetric framework. Journal of International Financial Markets Institutions and Money, v. 21, p. 92-106, 2011.

KIM, S.; KIM, S. H.; WANG, Y. Financial integration and consumption risk sharing in East Asia. Japan and the World Economy, v. 18, p. 143-157, 2006.

KIM, S.; LEE, J.-W. Real and Financial Integration in East Asia. Asian Development Bank. ADB Working Paper Series on Regional Economic Integration n. 17, 2008.

KIM, S.; LEE, J.; PARK, C. Emerging Asia: Decoupling or Recoupling? The World Economy, v. 34, n. 1, p. 23-53, 2011.

KIM, S.J.; MOSHIRIAN, F.; WU, E. Dynamic stock market integration driven by the European Monetary Union: an empirical analysis. Journal of Banking \& Finance, v. 29, p. 2475-2502, 2005.

KING, M. A.; WADHWANI, S. Transmission of volatility between sock markets. The Review of Financial Studies, v. 3, n. 1, p. 5-33, 1990.

KNELLER, R.; YU, Z. Quality selection, chinese exports and theories of heterogeneous firm trade. Research paper series 2008/44, 2008.

KNIF, J.; PYNNÖNEN, S. Local and global price memory of international stock markets. Journal of International Financial Markets, Institutions and Money, v. 9, p. 129-147, 1999.

KO, J-H.; PASCHA, W. Decoupling and Sources of Structural Transformation of East Asian Economies: International Input-Output Decomposition Analysis. Keio University, Tokyo. Working paper, 2011.

KORAJCZYK, R. A. A Measure of Stock Market Integration for Developed and Emerging Markets. The World Bank Policy Research Department. Policy Research World Paper n. 1482, $1995 . \quad$ Disponível em: http://elibrary.worldbank.org/content/workingpaper/10.1596/1813-9450-1482

KORINEK, A.; ROITMAN, A.; VÉGH, C. A. Decoupling and recoupling. NBER Working Paper 15907, 2010. Disponível em: http://www.nber.org/papers/w15907

KOSE, A.; OTROK, C.; PRASAD, E. Global business cycles: convergence or decoupling? International Economic Review, v. 53, n. 2, p. 511-538, 2012.

KOSE, M. A.; YI, K.-M. The Trade Co-movement Problem in International Macroeconomics. Federal Reserve Bank of New York Staff Report No. 155, 2002.

KOUTMOS, G. Modeling the dynamic interdependence of returns in major European stock markets. Journal of Business, Finance and Accounting, v. 23, p. 975-988, 1996.

KRUGMAN, P. Lessons of Massachusetts for EMU, in GIAVAZZI, F.; TORRES, F. The Transition to Economic and Monetary Union in Europe. NOVA YORK: Cambridge University Press, 1993. 
LEE, J-W.; PARK, C-Y. Global Financial Turmoil: Impact and Challenges for Asia's Financial Systems, Working paper, 2008. Disponível em: http://www.adb.org/sites/default/files/pub/2008/WP18-Impact-Challenges-Asia-FinancialSystems.pdf

LEVINE, R. International financial liberalization and economic growth. Review of International Economics, v. 9, n. 4, p. 688-702, 2001.

LEVINE, R.; ZERVOS, S. Stock Market Development and Long Run Growth, World Bank Economic Review, v. 10, n. 2, p. 323-40, 1996.

LEVY-YEYATI, E. On emerging markets decoupling and growth convergence. Vox Research-based policy analysis and commentary from leading economists, Nov. 2009. Disponível em: http://www.voxeu.org/article/decoupling-and-future-emerging-economiesgrowth

LIMA, I. S.; LIMA, G. A. S. F.; PIMENTEL, R. C. Curso de mercado financeiro: tópicos especiais. 1. ed. São Paulo: Atlas, 2006.

LIN, W.; ENGLE, R. F.; ITO, T. Do bulls and bears move across boarders? Transmission of stock returns and volatility. The Review of Financial Studies, v. 7, n. 3, p. 507-538, 1994.

LINDER, S. B. An Essay on Trade and Transformation. Nova Iorque: John Wiley \& Sons, 1961.

LONGIN, F.; SOLNIK, B. Is the correlation in international equity returns constant: 19701990. Journal of International Money and Finance, v. 14, p. 3-26, 1995.

LONGIN, F.; SOLNIK, B. 2001. Extreme correlation of international equity markets. The Journal of Finance, v. 56, p. 649-676, 2001.

MAJID, M. S. A.; KASSIM, S. H. Impact of the 2007 US financial crisis on the emerging equity markets. International Journal of Emerging Markets, v. 4, n.4, p. 341-357, 2009.

MASIH, A. M. M.; MASIH, R. Are Asian stock market fluctuations due mainly to intraregional contagion effects? Evidence based on Asian emerging stock markets. Pacific-Basin Finance Journal, v. 7, p. 251-282, 1999.

MASIH, R.; MASIH, A. M. M. Long and short term dynamic causal transmission amongst international stock markets. Journal of International Money and Finance, v. 20, p. 563$587,2001$.

MEDEIROS, C. A. A China como um duplo pólo na economia mundial e a recentralização da economia asiática. Revista Economia Política, v. 26, n.3, p. 381-400, 2006.

MEDEIROS, C. A. The Decoupling of Economic Growth in World Economy in the Last Decade and Development Strategies. Working paper, 2011. Disponível em: http://www.centrocelsofurtado.org.br/2011/Carlos_Medeiros_Novo_Desenvolvimentismo.pdf

MORALES, L. GASSIE, E. Structural breaks and financial volatility: lessons from BRIC countries. Working paper, 2011. Disponível em: http://www.iamo.de/fileadmin/uploads/forum2011/Papers/Morales_IAMO_Forum_2011.pdf 
NASSIF, A. A economia indiana no período 1950-2004 - Da estagnação ao crescimento acelerado: lições para o Brasil? BNDES. Texto para Discussão, n. 107, jan. 2006.

NAYYAR, D. China, India, Brazil and South Africa in the World Economy Engines of Growth? Discussion Paper No. 2008/05, 2008. Disponível em: http://www.wider.unu.edu/publications/working-papers/discussion papers/2008/en_GB/dp2008-05/

NIKKINEN, J.; SALEEM, K.; MARTIKAINEN, M. Transmission of the subprime crisis: Evidence from industrial and financial sector of BRIC countries. Working paper, 2012. Disponível em: http://regconf.hse.ru/uploads/e6b3b7cb902c5125533d35fc84304159440a8c87.pdf

O'NEIL, J. How Africa can become the next Bric. Financial Times. 26 ago. de 2010. Disponível em: http://www.ft.com/intl/cms/s/0/6c00e950-b153-11df-b89900144feabdc0.html\#axzz277NiY74m Acessado em: 20 de setembro de 2012.

ONO, S. Oil Price Shocks and Stock Markets in BRICs1. The European Journal of Comparative Economics, v. 8, n. 1, p. 29-45, 2011.

ONU - Organização das Nações Unidas. Disponível em: http://www.un.org/ Acessado em: 5 set. 2012.

OWEN, D; ROBINSON, D. O. Russia rebounds. International Monetary Fund. Working paper, 2003.

PAGANO, M. Financial markets and growth: An overview. European Ecomomic Review, v. 37, p. 613-622, 1993.

PAUTASSO, D. A África no Comércio Internacional do Grupo BRIC. Meridiano 47, v. 11, n. 120, p. 54-59, 2010.

PHYLAKTIS, K.; RAVAZZOLO, F. Measuring financial and economic integration with equity prices in emerging markets. Journal of International Money and Finance, v. 21, n. 6, p. 879-903, 2002.

PHYLAKTIS, K.; RAVAZZOLO, F. Stock market linkages in emerging markets: implications for international portfolio diversification. International Financial Markets, Institutions and Money, v. 15, p. 91-106, 2005.

PUlA, G.; PELTONEN, T. A. Has Emerging Asia Decoupled? An Analysis of Production and Trade Linkages Using the Asian International Input-Output Table. European Central Bank. Working Paper n. 993, jan. 2009.

QUAH, D. The shifting distribution of global economic activity. Economics Department LSE. Working paper, 2010. Disponível em: http://econ.lse.ac.uk/ dquah/p/2010.05Shifting_Distribution_GEA-DQ.pdf

RAHMAN, H.; YUNG, K. Atlantic and pacific stock markets correlation and volatility transmission. Global Finance Journal, v. 5, n. 1, p. 103-119, 1994. 
RANGEL, F. M. Preço de petróleo e mercado de ações: evidência do Mercado brasileiro. Dissertação (Mestrado) - Ibmec, Rio de Janeiro, 2012.

REDDY, P. Global R\&D Activities in India. UNCTAD, 2005. Disponível em: http://archive.unctad.org/sections/meetings/docs/reddy_india_en.pdf

ROSE, A.; ENGEL, C. Currency unions and international integration. Journal of Money, Credit and Banking, v. 34, p. 1067-1089, 2002.

ROSS, S. A. Information and Volatility: The No-Arbitrage Martingale Approach to Timing and Resolution Irrelevancy. Journal of Finance, v. 45, p. 1-17, 1989.

ROSSI, V. Decoupling debate will return: emergers dominate in long run. Working paper, 2008. Disponível em: http://www.chathamhouse.org/publications/papers/view/108911

SANTOS, J. O.; COELHO, P. A. Análise da relação risco e retorno em carteiras compostas por índices de bolsa de valores de países desenvolvidos e de países emergentes integrantes do bloco econômico BRIC. Revista Contabildade \& Finanças, v. 21, n. 54, p. 23-37, 2010.

SANTOS, L. B. Papel do BRIC na economia mundial. Mercator, v. 9, n. 19, p. 19-35, 2010.

SAUVANT, K. P. New sources of FDI: The BRICS. Outward FDI from Brazil, Russia, India and China. The Journal of World Investment \& Trade, v. 6, n. 5, p. 639 - 709, 2005.

SCHWERT, G. W. Why does stock market volatility change over time? Journal of Finance, v. 54, n. 5, p. 1115-1151, 1989.

SECURATO, J. R. Medindo o nível de globalização da América Latina e dos Estados Unidos. Anais do XXXII CLADEA. 1997.

SECURATO, J. R.; OLIVEIRA, E. F. Medindo o grau de globalização da economia 1990/1998. III SEME $\boldsymbol{A D}, 1998$.

SHALEN, C. T. Volume, Volatility, and the Dispersion of Beliefs. Review of Financial Studies, v. 6, p. 405-434, 1993.

SOUSA, M. O. M.; YOSHINO, J. A.; BIANCONI, M. A Crise Norte-Americana do Subprime - Impacto e Consequências para os BRICs (Parte 1). Informações FIPE. p. 23-29, 2011.

SUBACCHI, P. New power centres and new power brokers: are they shaping a new economic order? International Affairs, v. 84, n. 3, p. 485-498, 2008.

SUSMEL, R.; ENGLE, R. F. Hourly volatility spillovers between international equity markets. Journal of International Money and Finance, v. 13, p. 3-25, 1994.

THEODOSSIOU, P.; LEE, U. Mean and volatility spillovers across major national stock markets: further empirical evidence. Journal of Financial Research, v. 16, p. 337-350, 1993.

TRACZYK, A. Decoupling of Economies? Evidence from a Global VAR Analysis of Regional Spillovers. Goethe University Frankfurt. Working paper, 2010. 
TRAVAGLINI, F. Brics aprovam criação de fundo comum no valor de US\$ 100 bi. Estadão. Disponível em: http://economia.estadao.com.br/noticias/economia-brasil,bricsaprovam-criacao-de-fundo-comum-no-valor-de-us-100-bi,148463,0.htm Acessado em: 26 mar. 2013.

TRAVAGLINI, F.; DANTAS, I. Mantega propõe criar banco do Brics em 2014. Estadão. Disponível em: http://economia.estadao.com.br/noticias/economia-brasil,mantega-propoecriar-banco-do-brics-em-2014,148453,0.htm. Acessado em: 26 mar. 2013.

TSAY, R. S. Analysis of Financial Time Series. 2. ed. John Wiley \& Sons, 2005.

UMUTLU, M., AKDENIZ, L., ALTAG-SALIH, A., 2010. The degree of financial liberalization and aggregated stock-return volatility in emerging markets. Journal of Banking and Finance, v. 34, n. 3, p. 485-696, 2010.

VIEIRA, F. V.; VERÍSSIMO, M. P. Crescimento econômico em economias emergentes selecionadas: Brasil, Rússia, Índia, China (BRIC) e África do Sul. Economia e Sociedade, v. 18, n. 3, p. 513-546, 2009.

WÄLTI, S. No decoupling, more interdependence: business cycle comovements between advanced and emerging economies. Swiss National Bank. Working paper, 2010. Disponível em: http://mpra.ub.uni-muenchen.de/20869/1/euclid.pdf

WÄLTI, S. The myth of decoupling. Swiss National Bank. Working paper, 2009. Disponível em: http://www.sgvs.ch/congress09/upload/p_41.pdf

WALZ, R. Systems of sustainability innovations - conceptual issues and first empirical results for the BRICS Countries. Department, Institute Systems and Innovation Research, Germany. Working paper, 2007. Disponível em: http://russianlics.sstu.ru/globelics.nsf/0/8AC2EAE32954B4E0C32572AF00552B8C/\$File/pa per-Walz-July.pdf

WILlET, T. D.; LIANG, P.; ZHANG, N. Global Contagion and the Decoupling Debate. Frontier of Economics and Globalization, v. 9, p.215-234, 2011.

WILSON, D.; PURUSHOTHAMAN, R. Dreaming with BRICs: The Path to 2050. Goldman Sachs. Global Economics Paper No. 9, 2003. Disponível em: http://www.goldmansachs.com/our-thinking/topics/brics/brics-reports-pdfs/brics-dream.pdf Acessado em: 20 de setembro de 2012.

WONGSWAN, J. Transmission of Information across International Equity Markets. The Review of Financial Studies, v. 19, n. 4, p. 1157-1189, 2006.

YU, I.; FUNG, K.; TAM, C. Assessing financial market integration in Asia - Equity markets. Journal of Banking \& Finance, v. 34, p. 2874-2885, 2010. 